\title{
Synthesis and NMR Elucidation of Novel Octa-Amino Acid Resorcin[4]arenes Derivatives
}

\author{
Iman Elidrisi, ${ }^{a}$ Pralav V. Bhatt, ${ }^{\mathrm{b}}$ Thavendran Govender, \\ Hendrik G. Kruger, ${ }^{b}$ and Glenn E.M. Maguire ${ }^{a, t}$ \\ ${ }^{a}$ School of Chemistry and Physics, University of KwaZulu-Natal, Westville Campus, Private Bag X54001, Durban, 4000, South Africa. \\ ${ }^{b}$ School of Pharmacology, University of KwaZulu-Natal, Westville Campus, Private Bag X54001, Durban, 4000, South Africa.
}

Received 25 September 2014, revised 14 January 2015, accepted 14 January 2014.

\begin{abstract}
The synthesis of nine novel protected amino acid cavitands is reported. All have four pendant $n$-undecyl chains and 'headgroups' connected by a two-carbon spacer at eight positions on the aromatic rings. The amino acids employed are glycine, alanine, phenylalanine, leucine, proline, tryptophan, serine, glutamine and lysine. The structures of the compounds were elucidated using one and two-dimensional NMR techniques which verified that all octa-substituted cavitands have symmetrical $C_{2 v}$ conformation at room temperature. These compounds have potential synthetic ion channel applications.
\end{abstract}

KEYWORDS

Octa-amino acid resorcin[4]arenes, ${ }^{1} \mathrm{H}-\mathrm{NMR}, \mathrm{COSY}, \mathrm{HSQC}, C_{4 v}$ symmetry, $C_{2 v}$ symmetry.

\section{Introduction}

Resorcin[4]arenes are well-known macrocyclic oligomers formed when resorcinol condenses with aliphatic or aromatic aldehydes under acidic conditions. ${ }^{1}$ The reaction with formaldehyde is excluded from this 'family' as it often forms linear polymers. Even though it is possible to form resorcinarenes with formaldehyde, ${ }^{2}$ the use of aliphatic aldehydes resulting in side chains or 'feet' is preferred for potential synthetic ion channels. ${ }^{3}$ These macrocyclic compounds are known to possess hydrophilic (upper rim) and hydrophobic (lower rim) regions and a cavity, that can accommodate small organic molecules. ${ }^{4}$

Resorcin[4]arenes are not planar and can adopt five possible conformational arrangements: the $C_{4 v}$ symmetrical 'crown' conformation, $C_{2 v}$ symmetrical 'boat' conformation, $C_{2 h}$ symmetrical 'chair' conformation, $C_{s}$ symmetrical 'diamond' conformation, and $S_{4}$ symmetrical 'saddle' conformation as illustrated in Fig. $1{ }^{4 \mathrm{~b}}$

The presence of two electron-releasing hydroxyl groups on the aromatic rings especially at the 'ortho' position makes compounds of this family a convenient platform for the design and synthesis of various supramolecular structures. To obtain these architectures, various methods have been developed for selective chemical modifications of the resorcin[4]arenes. ${ }^{4 b, 5}$ Functionalization of the resorcin[4]arene platform with amino acid moieties could create structural features that provide valuable insight into factors governing biologically relevant host-guest chemistry. ${ }^{6}$ These types of compounds also have found applications as synthetic ion channels. ${ }^{3,7}$.

This study demonstrates an effort to functionalize resorcin[4] arene with amino acid residues at the upper rim. Very few examples have been reported where 'flexible' resorcin[4]arenes have been modified with amino acids. An example employing L-proline via Mannich reactions has been reported by several researchers. ${ }^{8}$ Botta et al. using a different approach have modified resorcin[4]arenes at the lower rim with several amino acids for chiral recognition. ${ }^{9}$

The synthesis of our target compounds began by utilizing

* To whom correspondence should be addressed. E-mail: maguireg@ukzn.ac.za dodecanal, as the alkyl aldehyde component for the condensation reaction with resorcinol, to produce the resorcin[4]arene, 1 in good yield as reported in literature. ${ }^{1 \mathrm{~b}, 10}$ Acylations and alkylations of hydroxyl groups have produced cavitands, carcerands, hemicarcerands, velcrands, ${ }^{4 a}$ molecular capsules, ${ }^{11}$ receptors and sensors for biologically-active compounds, ${ }^{12}$ and metal ion extraction agents. ${ }^{13}$

The synthetic route towards novel compounds $4 \mathbf{a}-\mathbf{i}$ (Scheme 1), involves alkylation of compound $\mathbf{1}$ with methyl-2-bromoacetate in dry acetonitrile in the presence of potassium carbonate and a catalytic amount of sodium iodide. The reaction occurs at elevated temperature for $48 \mathrm{~h}$ and after workup and recrystallization pure 2 was obtained in $77 \%$ yield. ${ }^{13 a, 14}$

\section{Results and Discussion}

These compounds may find application as synthetic ion channels, but testing of the compounds reported herein for that, falls outside the scope of the current NMR investigation.

The structures of these compounds were established on the basis of one- and two-dimensional NMR experiments. A discussion of the complete elucidation of compound $4 \mathbf{a}$ is presented, followed with a short discussion of $2 \mathrm{D}$ results for $4 \mathbf{b}$. Elucidation of the remainder of the compounds is presented in the online supplement. A summary of the NMR data are presented in Tables 1-3.

Octa-acid resorcin[4]arene 3 was transformed into the octa-acyl chloride upon treatment with oxalyl chloride in dry $\mathrm{CH}_{2} \mathrm{Cl}_{2}$ (Scheme 1). Since the acyl chloride is very unstable and undergoes rapid hydrolysis if moisture is present, it was used in the next step without further purification and characterization. This acyl chloride was reacted with nine equivalents of each amino acid, to the get the novel derivatives..$^{15}$ A number of the amino acids required side chain protection (e.g. L-glutamic acid, L-serine, and L-lysine). The crude materials obtained were purified on silica gel chromatography, using $3 \%$ methanol in chloroform. The octa-amino acid resorcin[4]arene derivatives $4 \mathbf{a}-\mathbf{i}$ were obtained in good yields (59-76\%). 


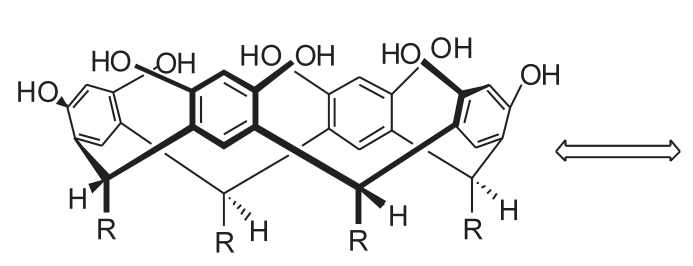

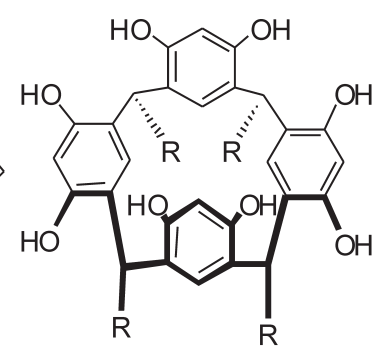

crown- $C_{4 v}$

boat- $C_{2 v}$

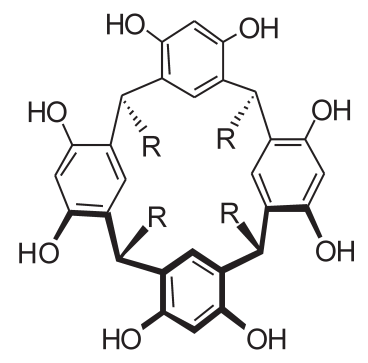

chair- $C_{2 h}$<smiles>[R]C(c1cc(C)c(O)cc1O)c1cc(C([R])c2cc(C([R])c3cc(C([R])c4cc(C([R])c5cc(O)c(O)cc5O)c(O)cc4O)c(O)cc3O)c(O)cc2O)c(O)cc1O</smiles>

diamond- $C_{s}$

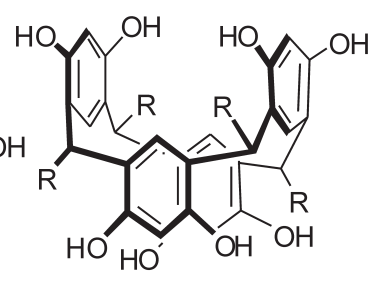

saddle- $S_{4}$

Figure 1 The different conformations of macrocyclic resorcin[4]arene. ${ }^{4 b}$

The ${ }^{1} \mathrm{H}$ NMR spectra of these derivatives $(4 \mathbf{a}-\mathbf{i})$ in $\mathrm{CDCl}_{3}$ at room temperature showed a considerable broadening of the various signals. The relatively broad signals from these compounds are a result of the multiple conformations possible for the cavitand bowl. On the NMR timescale, they have a slow rate of interconversion. Boat conformations convert to a symmetrical crown conformation and vice versa ${ }^{1 \mathrm{a}, 10 a, 16}$. A similar observation was made when the spectra of these molecules were taken in polar organic solvents at room temperature $\left(\mathrm{d}_{6}\right.$-acetone and $d_{6}$-DMSO). Figures 2, 3 and 4 illustrate these observations

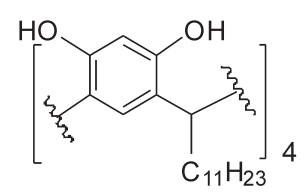

$1(75 \%)$

\section{Methy-2-bromoacetate, $\mathrm{CH}_{3} \mathrm{CN}$ \\ $\mathrm{K}_{2} \mathrm{CO}_{3}, \mathrm{Nal}$, reflux, $48 \mathrm{~h}$}

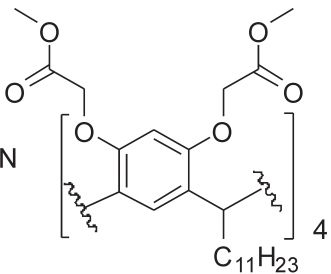

$2(77 \%)$

$2 \mathrm{M} \mathrm{KOH}, \mathrm{EtOH}$,

reflux, $3 \mathrm{~h}$

i) Oxalyl chloride, dry $\mathrm{CH}_{2} \mathrm{Cl}_{2}$, reflux

ii) Amino acid ester, $\mathrm{Et}_{3} \mathrm{~N}$, dry $\mathrm{CH}_{2} \mathrm{Cl}_{2}, 0{ }^{\circ} \mathrm{C}$, rt

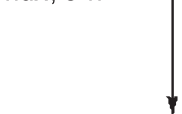<smiles>[R]C(=O)COc1cc(OCC([R])C)c(C(C)CC)cc1CC</smiles>

4a-i $(59-76 \%)$<smiles>CCCCCCC(C)c1cc(CC)c(OCC(=O)O)cc1OCC(=O)O</smiles>

$3(93 \%)$
4a $R^{\prime}=$ Gly ethyl ester
4b $\mathrm{R}^{\prime}=\mathrm{L}$-Ala methyl ester
4c $R^{\prime}=$ L-Phe methyl ester
4d $\mathrm{R}^{\prime}$ = L-Leu methyl ester

4f $\mathrm{R}^{\prime}=\mathrm{L}$-Trp methyl ester

4g R' = L-Ser (Ot-but) t-butyl ester

4h $\mathrm{R}^{\prime}$ = L-Glu (OMe) methyl ester

4i $\mathrm{R}^{\prime}=\mathrm{L}$-Lys (Z) benzyl ester

Scheme 1 Synthetic pathway towards the octa-amino acid-resorcin[4]arene derivatives 4a-i via modification of all eight hydroxyl groups. 
Table $1{ }^{1} \mathrm{H}$ NMR data for compounds $4 \mathrm{a}-\mathrm{c}$ in DMSO- $\mathrm{d}_{6}$ at $70{ }^{\circ} \mathrm{C}(600 \mathrm{MHz})$.

\begin{tabular}{|c|c|c|c|}
\hline \multirow[b]{2}{*}{ Proton } & \multicolumn{3}{|c|}{ Chemical shift/ppm (multiplicity, coupling constant, integration) } \\
\hline & $4 a$ & $4 \mathrm{~b}$ & $4 \mathrm{c}$ \\
\hline $\mathrm{H}_{2}$ & $4.69(t, J=8.0 \mathrm{~Hz}, 4)$ & $4.67(t, J=5.0 \mathrm{~Hz}, 4)$ & $4.64(t, J=8.0 \mathrm{~Hz}, 4)$ \\
\hline $\mathrm{H}_{3}$ & $6.73(s, 4)$ & $6.73(s, 4)$ & $6.89(s, 4)$ \\
\hline $\mathrm{H}_{4}$ & $6.57(s, 4)$ & $6.56(s, 4)$ & $6.33(s, 4)$ \\
\hline $\mathrm{H}_{5}$ & $\begin{array}{l}4.36(d, J=14.7 \mathrm{~Hz}, 8) \\
4.27(d, J=14.7 \mathrm{~Hz}, 8)\end{array}$ & $\begin{array}{l}4.35(q, J=5.0 \mathrm{~Hz}, 8) \\
4.24(q, J=5.0 \mathrm{~Hz}, 8)\end{array}$ & $\begin{array}{l}4.20(q, J=7.1 \mathrm{~Hz}, 8) \\
4.28(q, J=7.1 \mathrm{~Hz}, 8)\end{array}$ \\
\hline $\mathrm{NH}$ & $\begin{array}{l}7.72(t, J=5.1 \mathrm{~Hz}, 8 \mathrm{H}) \\
7.82(d, J=7.3 \mathrm{~Hz}, 4)\end{array}$ & $\begin{array}{l}7.80(d, J=7.3 \mathrm{~Hz}, 4) \\
7.77(d, J=8.2 \mathrm{~Hz}, 4)\end{array}$ & $7.60(d, J=8.2 \mathrm{~Hz}, 4)$ \\
\hline $\mathrm{AAH}^{*}$ & $\begin{array}{l}4.12(q, J=7.0 \mathrm{~Hz}, 16) ; \\
3.96(d d, J=5.1 \mathrm{~Hz}, 8) \\
3.85(d d, J=5.8 \mathrm{~Hz}, 8) \\
1.20(t, J=8.5 \mathrm{~Hz} 24)\end{array}$ & $\begin{array}{l}4.42(q, J=8.5 \mathrm{~Hz}, 8) \\
3.64(d, J=7.0 \mathrm{~Hz}, 24) \\
1.34(t, J=7.2 \mathrm{~Hz}, 24)\end{array}$ & $\begin{array}{l}7.04-7.15(m, 40) ; \\
4.64(q, J=6.3 \mathrm{~Hz}, 8) ; \\
3.59(d, J=7.1 \mathrm{~Hz}, 24) ; \\
3.11(d d, J=6.0 \mathrm{~Hz}, 4) ; \\
3.04(d d, J=6.0 \mathrm{~Hz}, 4) ; \\
3.03(d d, J=6.3 \mathrm{~Hz}, 4) ; \\
2.87(d d, J=6.3 \mathrm{~Hz}, 4)\end{array}$ \\
\hline Feet & $\begin{array}{l}1.81(q, J=6.5 \mathrm{~Hz}, 8) ; \\
1.22-1.27(m, 72) ; \\
0.84(t, J=7.5 \mathrm{~Hz}, 12)\end{array}$ & $\begin{array}{l}1.83(q, J=6.5 \mathrm{~Hz}, 8) \\
1.20-1.28(m, 72) \\
0.84(t, J=6.0 \mathrm{~Hz}, 12)\end{array}$ & $\begin{array}{l}2.17(q, J=7.0 \mathrm{~Hz}, 8) \\
1.20-1.28(m, 72) \\
0.83(t, J=6.3 \mathrm{~Hz}, 12)\end{array}$ \\
\hline
\end{tabular}

$\mathrm{AAH}^{*}$ denotes amino acid ester peaks.

for compound $4 \mathrm{a}$ in different solvents. The ${ }^{1} \mathrm{H}$ NMR spectra of this derivative show relatively broad signals corresponding to the aromatic protons (assigned $a$ and $b$ ).

In an attempt to confirm that the broadening in the ${ }^{1} \mathrm{H}$ NMR spectra is the result of these conformational changes, $4 \mathbf{a}$ in $\mathrm{d}_{6}$-DMSO was heated in the NMR spectrometer $(600 \mathrm{MHz})$. By increasing the temperature stepwise, the various signals began to sharpen. At $70{ }^{\circ} \mathrm{C}$, only the signals of the crown conformation are visible in the spectrum. ${ }^{1} \mathrm{H}$ NMR spectrum of this compound shows sharp single peaks corresponding to the aromatic protons (assigned at $6.73 \mathrm{ppm}$ and $6.57 \mathrm{ppm}$ ) (Fig. 5).

To further establish the conformational behaviour for these compounds (4a-i), a low temperature ${ }^{1} \mathrm{H}$ NMR experiment was recorded for compound $4 \mathrm{a}$ in $\mathrm{d}_{6}$-acetone at $600 \mathrm{MHz}$ from $0{ }^{\circ} \mathrm{C}$ to $-60{ }^{\circ} \mathrm{C}$. The most notable change in the ${ }^{1} \mathrm{H}$ NMR spectrum occurred for the signals of the aromatic protons $\left(\mathrm{H}_{3}\right.$ and $\mathrm{H}_{4}$
Fig. 3). As the solution cooled down to $-40{ }^{\circ} \mathrm{C}$, the signals for $\mathrm{H}_{3}$ and $\mathrm{H}_{4}$ broadened and separated into four signals (6.30 ppm and $6.57 \mathrm{ppm}_{\text {for }} \mathrm{H}_{4}$, and $6.89 \mathrm{ppm}$ and $7.47 \mathrm{ppm}$ for $\mathrm{H}_{3}$ ) (Fig. 6).

Figure 6 illustrates the splitting of the aromatic protons signals into four broad singlets at low temperature, indicating the flattened conformations corresponded to a $C_{2 v}$ symmetry for $4 \mathbf{a}$, in which the aromatic rings lie spatially in pairs. As anticipated, the ${ }^{1} \mathrm{H}$ NMR spectrum in Fig. 3 also displayed some changes in the non-aromatics regions for this compound.

To discuss the proton $\left({ }^{1} \mathrm{H}\right)$ NMR spectrum of compound 4a in DMSO $-\mathrm{d}_{6}$ at $70{ }^{\circ} \mathrm{C}$ reference will be made to Fig. 7 , which shows the numbering of the protons present in this molecule. According to this expanded structure, the various resonances present in the ${ }^{1} \mathrm{H}$ NMR spectra of the macrocycles $4 \mathbf{b}-\mathbf{i}$ were assigned.

The ${ }^{1} \mathrm{H}$ NMR spectrum for compound $4 \mathrm{a}$ in $\mathrm{d}_{6}$-DMSO at $70{ }^{\circ} \mathrm{C}$ demonstrates signals characteristic for the glycine ethyl ester

Table $2{ }^{1} \mathrm{H}$ NMR data for compounds $4 \mathbf{d d}-\mathbf{f}$ in DMSO- $\mathrm{d}_{6}$ at $70{ }^{\circ} \mathrm{C}(600 \mathrm{MHz})$.

\begin{tabular}{|c|c|c|c|}
\hline \multirow[b]{2}{*}{ Proton } & \multicolumn{3}{|c|}{ Chemical shift/ppm (multiplicity, coupling constant, integration) } \\
\hline & $\overline{4 d}$ & $4 e$ & $4 \mathrm{f}$ \\
\hline $\mathrm{H}_{2}$ & $4.77(t, J=7.5 \mathrm{~Hz}, 4)$ & $4.68(t, J=7.9 \mathrm{~Hz}, 4)$ & $4.63(t, J=8.0 \mathrm{~Hz}, 4)$ \\
\hline $\mathrm{H}_{3}$ & $6.89(s, 4)$ & $6.82(b r s, 4)$ & $6.80(s, 4)$ \\
\hline $\mathrm{H}_{4}$ & $6.53(s, 4)$ & $6.38(b r s, 4)$ & $6.47(s, 4)$ \\
\hline $\mathrm{H}_{5}$ & $\begin{array}{l}4.46(q, J=7.1 \mathrm{~Hz}, 8) \\
4.36(t, J=7.6 \mathrm{~Hz}, 8)\end{array}$ & $4.48(b r d, 16)$ & $\begin{array}{l}4.32(q, J=7.0 \mathrm{~Hz}, 8) \\
4.26(q, J=7.2 \mathrm{~Hz}, 8)\end{array}$ \\
\hline $\mathrm{NH}$ & $\begin{array}{l}8.02(d, J=8.1 \mathrm{~Hz}, 4) \\
7.79(d, J=8.1 \mathrm{~Hz}, 4)\end{array}$ & - & $\begin{array}{l}7.63(d, J=7.56 \mathrm{~Hz}, 4) \\
7.55(d, J=7.68 \mathrm{~Hz}, 4)\end{array}$ \\
\hline $\mathrm{AAH}^{*}$ & $\begin{array}{l}4.47(q, J=3.56 \mathrm{~Hz}, 8) ; \\
3.62(d, J=17.5 \mathrm{~Hz}, 24) ; \\
1.45-1.67(m, 24) ; \\
0.87(t, J=7.5 \mathrm{~Hz}, 24) ; \\
0.77(t, J=7.2 \mathrm{~Hz}, 24)\end{array}$ & $\begin{array}{l}4.38(q, J=5.66 \mathrm{~Hz}, 8) ; \\
3.69(d, J=7.3 \mathrm{~Hz}, 24) ; \\
3.56(m, 16) ; \\
1.90(q, J=4.3 \mathrm{~Hz}, 8) ; \\
2.00-2.15(m, 24)\end{array}$ & $\begin{array}{l}10.42(s, 4) ; 10.32(s, 4) ; \\
7.48(t, J=6.5 \mathrm{~Hz}, 8) ; \\
7.29(d d, J=8.10 \mathrm{~Hz}, 8) ; \\
7.02(t, J=7.4 \mathrm{~Hz}, 8) ; \\
7.00(t, J=7.5 \mathrm{~Hz}, 8) ; \\
6.90(s, 4) ; \\
4.71(q, J=7.1 \mathrm{~Hz}, 8) ; \\
3.68(d, J=6.5 \mathrm{~Hz}, 24) ;\end{array}$ \\
\hline Feet & $\begin{array}{l}1.81(q, J=6.7 \mathrm{~Hz}, 8) ; \\
1.20-1.28(m, 72) ; \\
0.84(t, J=7.1 \mathrm{~Hz}, 12)\end{array}$ & $\begin{array}{l}2.41(m, 8) ; \\
1.20-1.30(m, 72) ; \\
0.86(t, J=6.5 \mathrm{~Hz}, 12)\end{array}$ & $\begin{array}{l}1.83(q, J=7.7 \mathrm{~Hz}, 8) \\
1.20-1.28(m, 72) ; \\
0.85(t, J=6.5 \mathrm{~Hz}, 12)\end{array}$ \\
\hline
\end{tabular}

$\mathrm{AAH}^{*}$ denotes amino acid ester peaks. 
Table $3{ }^{1} \mathrm{H}$ NMR data for compounds $4 \mathrm{~g}-\mathrm{i}$ in $\mathrm{d}_{6}-\mathrm{DMSO}$ at $70{ }^{\circ} \mathrm{C}(600 \mathrm{MHz})$.

\begin{tabular}{|c|c|c|c|}
\hline \multirow[b]{2}{*}{ Proton } & \multicolumn{3}{|c|}{ Chemical shift/ppm (multiplicity, coupling constant, integration) } \\
\hline & $4 \mathrm{~g}$ & $4 \mathrm{~h}$ & $4 \mathbf{i}$ \\
\hline $\mathrm{H}_{2}$ & $4.63(t, J=8.0 \mathrm{~Hz}, 4)$ & $4.69(t, J=7.2 \mathrm{~Hz}, 4)$ & $4.68(t, J=7.2 \mathrm{~Hz}, 4)$ \\
\hline $\mathrm{H}_{3}$ & $6.73(s, 4)$ & $6.81(s, 4)$ & $6.84(s, 4)$ \\
\hline $\mathrm{H}_{4}$ & $6.53(s, 4)$ & $6.55(s, 4)$ & $6.59(s, 4)$ \\
\hline $\mathrm{H}_{5}$ & $\begin{array}{l}4.36(d, J=14.70 \mathrm{~Hz}, 4) ; \\
4.28(d, J=14.94 \mathrm{~Hz}, 4) ; \\
4.25(d, J=14.88 \mathrm{~Hz}, 4) ; \\
4.18(d, J=14.82 \mathrm{~Hz}, 4)\end{array}$ & $\begin{array}{l}4.32(q, J=8.56 \mathrm{~Hz}, 8) \\
4.30(q, J=7.9 \mathrm{~Hz}, 8)\end{array}$ & $\begin{array}{l}4.35(q, J=8.42 \mathrm{~Hz}, 8) ; \\
4.27(q, J=8.0 \mathrm{~Hz}, 8)\end{array}$ \\
\hline $\mathrm{NH}$ & $\begin{array}{l}7.27(d, J=8.2 \mathrm{~Hz}, 4) \\
7.24(d, J=8.1 \mathrm{~Hz}, 4)\end{array}$ & $7.66(d d, J=7.4 \mathrm{~Hz}, 8)$ & $7.61(d d, J=7.8 \mathrm{~Hz}, 8)$ \\
\hline $\mathrm{AAH}^{*}$ & $\begin{array}{l}4.46(q, J=5.72 \mathrm{~Hz}, 8) ; \\
3.70(d d, J=3.1 \mathrm{~Hz}, 8) ; \\
3.54(d d, J=2.6 \mathrm{~Hz}, 8) ; \\
1.40(d, J=3.5 \mathrm{~Hz}, 72) ; \\
1.09(d, 72)\end{array}$ & $\begin{array}{l}4.44(q, J=8.56 \mathrm{~Hz}, 8) ; \\
3.70(s, 24) ; \\
3.58(d, J=3.81 \mathrm{~Hz}, 24) ; \\
2.36(q, J=4.2 \mathrm{~Hz}, 16) ; \\
2.13(m, 8) ; 1.96(m, 8)\end{array}$ & $\begin{array}{l}7.26-7.36(m, 80) ; \\
6.61(b r t, 8) ; \\
5.13(m, 16) ; \\
4.77(s, 16) ; \\
4.44(q, J=6.1 \mathrm{~Hz}, 8) ; \\
3.10(q, J=5.2 \mathrm{~Hz}, 16) ; \\
1.82(m, 8) ; 1.78(m, 8) ; \\
1.39(m, 32)\end{array}$ \\
\hline Feet & $\begin{array}{l}1.86(q, J=6.4 \mathrm{~Hz}, 8) \\
1.20-1.28(m, 72) ; \\
0.86(t, J=6.5 \mathrm{~Hz}, 12)\end{array}$ & $\begin{array}{l}1.86(q, J=5.1 \mathrm{~Hz}, 8) \\
1.20-1.29(m, 72) ; \\
0.87(t, J=6.5 \mathrm{~Hz}, 12)\end{array}$ & $\begin{array}{l}1.86(q, J=6.8 \mathrm{~Hz}, 8) \\
1.20-1.28(m, 72) \\
0.80(t, J=6.7 \mathrm{~Hz}, 12)\end{array}$ \\
\hline
\end{tabular}

$\mathrm{AAH}^{*}$ denotes amino acid ester peaks.

and the resorcin[4]arene scaffold. The signal related to the methylene group of the ethyl ester at $4.12 \mathrm{ppm}$ appears as a quartet, integrating to 16 . The signal associated with the methyl group of this ester at $1.20 \mathrm{ppm}$ is a triplet, integrating to 24 . The signal related to the $\alpha$-protons (Fig. 7) appears as two pairs of doublets at $3.96 \mathrm{ppm}$ and $3.85 \mathrm{ppm}$, each of these integrates to eight. The signal for the amide NH protons for this derivative appears as a triplet at $7.72 \mathrm{ppm}$, integrating to eight.

The signal for the methylene protons $\left(\mathrm{H}_{5}\right)$ of the $\mathrm{OCH}_{2} \mathrm{CO}$ groups appears as two doublets at $4.36 \mathrm{ppm}$ and at $4.27 \mathrm{ppm}$, each of these signals integrates to eight. This splitting could be attributed to the presence of two glycine residues on each aromatic ring. The signals related to the protons of aromatic rings $\left(\mathrm{H}_{3}\right.$ and $\left.\mathrm{H}_{4}\right)$ appear as two singlets at 6.73 ppm for $\mathrm{H}_{3}$ protons and at $6.57 \mathrm{ppm}$ for $\mathrm{H}_{4}$ protons, each of these integrates to four. The signal associated with the methine protons $\left(\mathrm{H}_{2}\right)$ at $4.69 \mathrm{ppm}$ is a triplet, integrating to four. The signals related to the undecyl 'feet' (R) have resolved into three signals: a quartet at $1.81 \mathrm{ppm}$, integrating to eight, multiplets at $1.22-1.27 \mathrm{ppm}$, integrating to 72 , and a triplet at $0.84 \mathrm{ppm}$, integrating to 12 .

The IR spectrum for 4 a shows the characteristic appearance of the amide $\mathrm{NH}$ stretching peak at $3414 \mathrm{~cm}^{-1}$ whereas the carbonyl peaks at 1757 and $1731 \mathrm{~cm}^{-1}$ corresponding to the ester and amide carbonyl stretching frequencies, respectively. Mass spectrometry

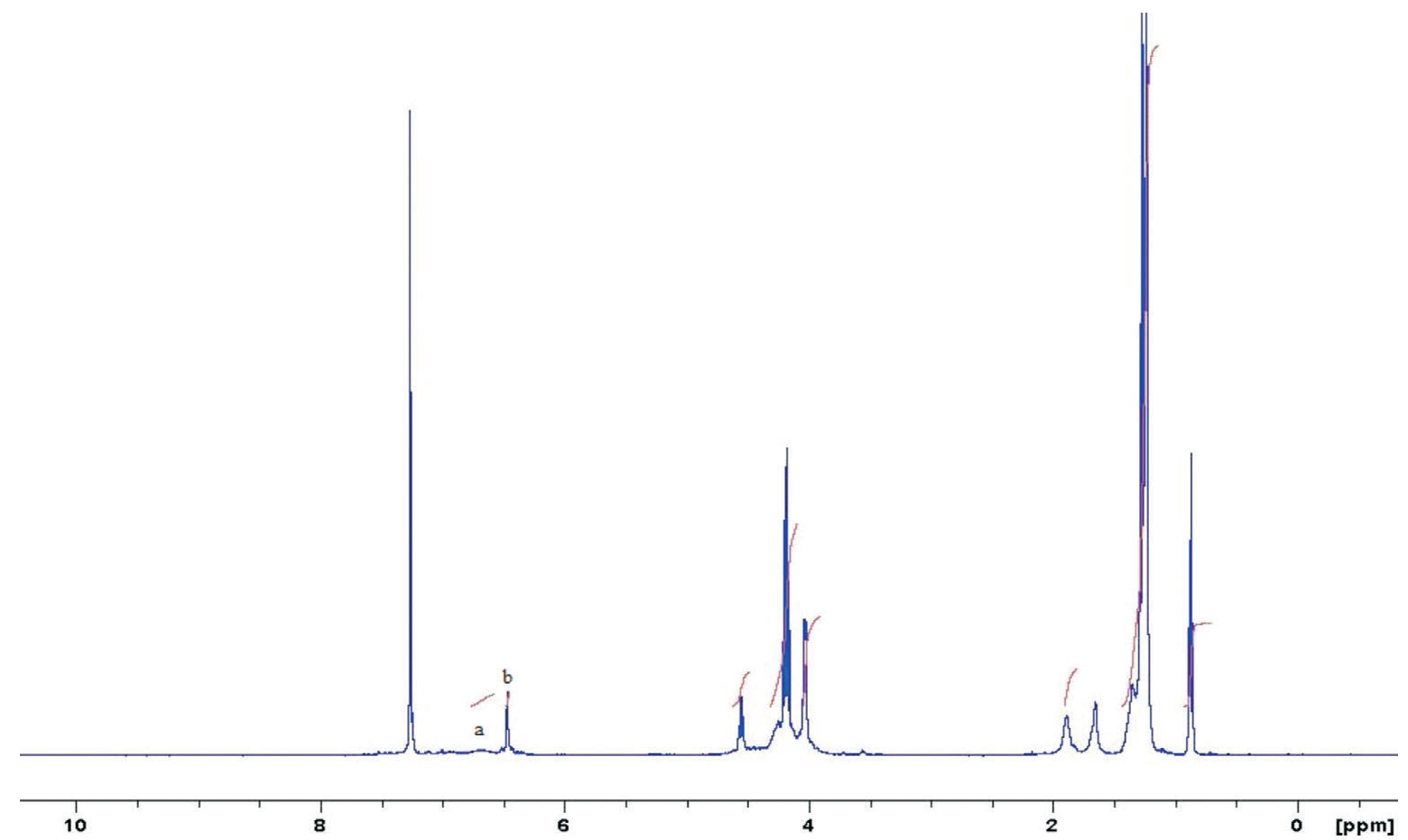

Figure $2{ }^{1} \mathrm{H}$ NMR spectrum of compound 4 a in $\mathrm{CDCl}_{3}$ at room temperature $(400 \mathrm{MHz})$. 


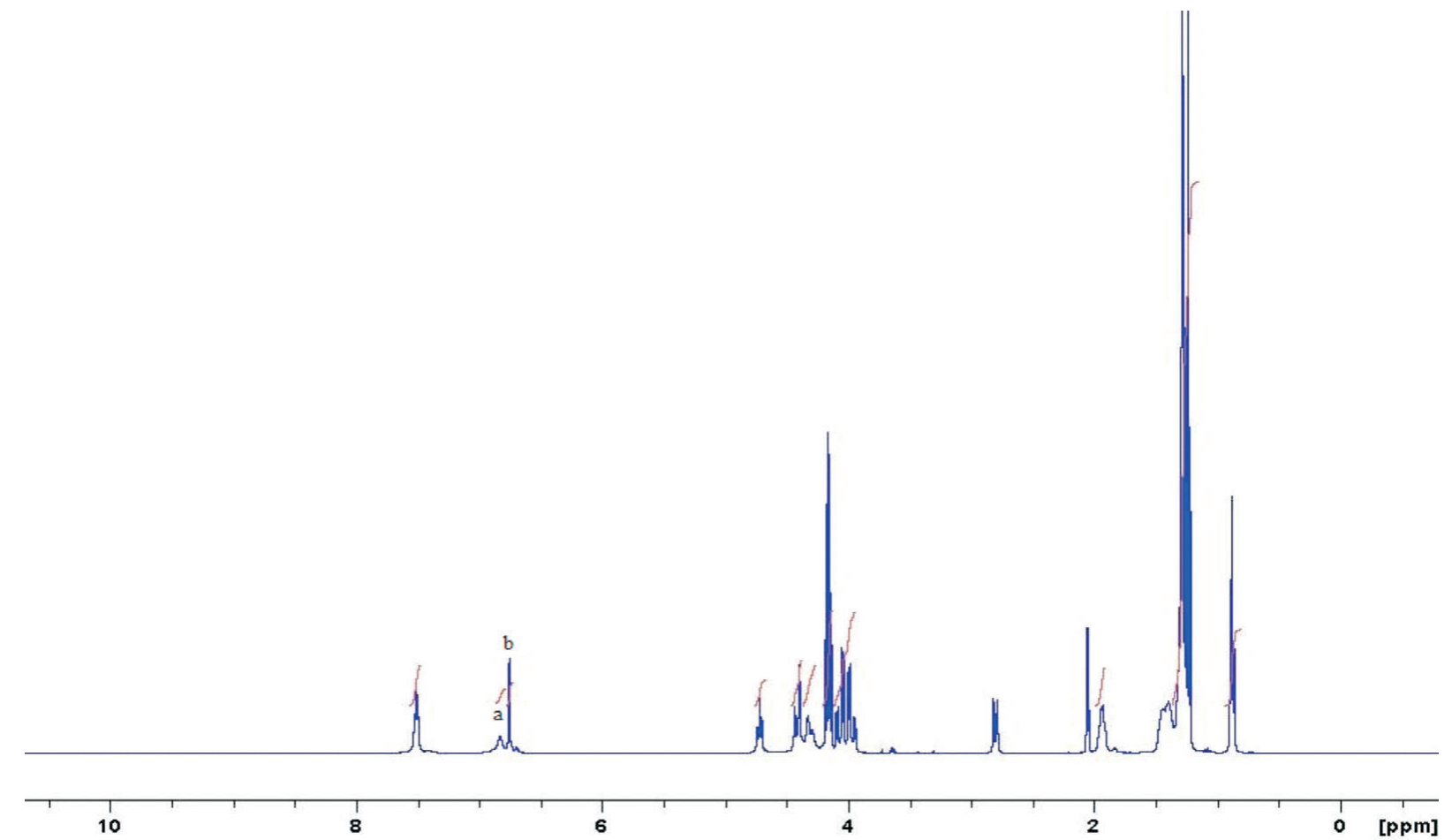

Figure $3{ }^{1} \mathrm{H}$ NMR spectrum of compound $4 \mathrm{a}$ in $\mathrm{d}_{6}$-acetone at room temperature $(400 \mathrm{MHz})$.

(MS) (using ESI-TOF methods) additionally gave a molecular ion $\mathrm{m} / \mathrm{z}$ signal of 2273.2926, which matches the expected mass for 4a of 2273.2942.

Compound $\mathbf{4 b}$ was synthesized in $73 \%$ yield by reacting L-alanine methyl ester with the octa-acid resorcin[4]arene 3 . The ${ }^{1} \mathrm{H}$ NMR data for compounds $4 \mathrm{a}-\mathrm{c}$ are summarized in Table 1.

Subsequent COSY and HSQC NMR analysis confirmed the presence of the target compounds, showing the expected couplings between the various protons. Figure 7 displays ${ }^{1} \mathrm{H}-{ }^{1} \mathrm{H}$
COSY couplings for compound $4 \mathbf{b}$, as an example of a twodimensional NMR experiment at $70{ }^{\circ} \mathrm{C}(600 \mathrm{MHz}$. $)$

Analysis of the COSY spectrum shows (Fig. 8) that the $\alpha$-protons (Ala-CH-) at $4.35 \mathrm{ppm}$ are coupled to the amide $\mathrm{NH}$ protons at $7.82 \mathrm{ppm}$ and $7.80 \mathrm{ppm}$ as well as the $\beta$-protons $\left(\mathrm{Ala}-\mathrm{CH}_{3}\right)$ at $1.34 \mathrm{ppm}$. The methine protons $\left(\mathrm{H}_{2}\right)$ at $4.67 \mathrm{ppm}$ which bridge the aromatic moieties, are coupled to the methylene protons of the 'feet' $\left(-\mathrm{CH}_{2}-\right)$ at $1.83 \mathrm{ppm}$. The methylene protons at $1.83 \mathrm{ppm}$ are coupled to the protons of the 'feet' at $1.20-1.28 \mathrm{ppm}$. The

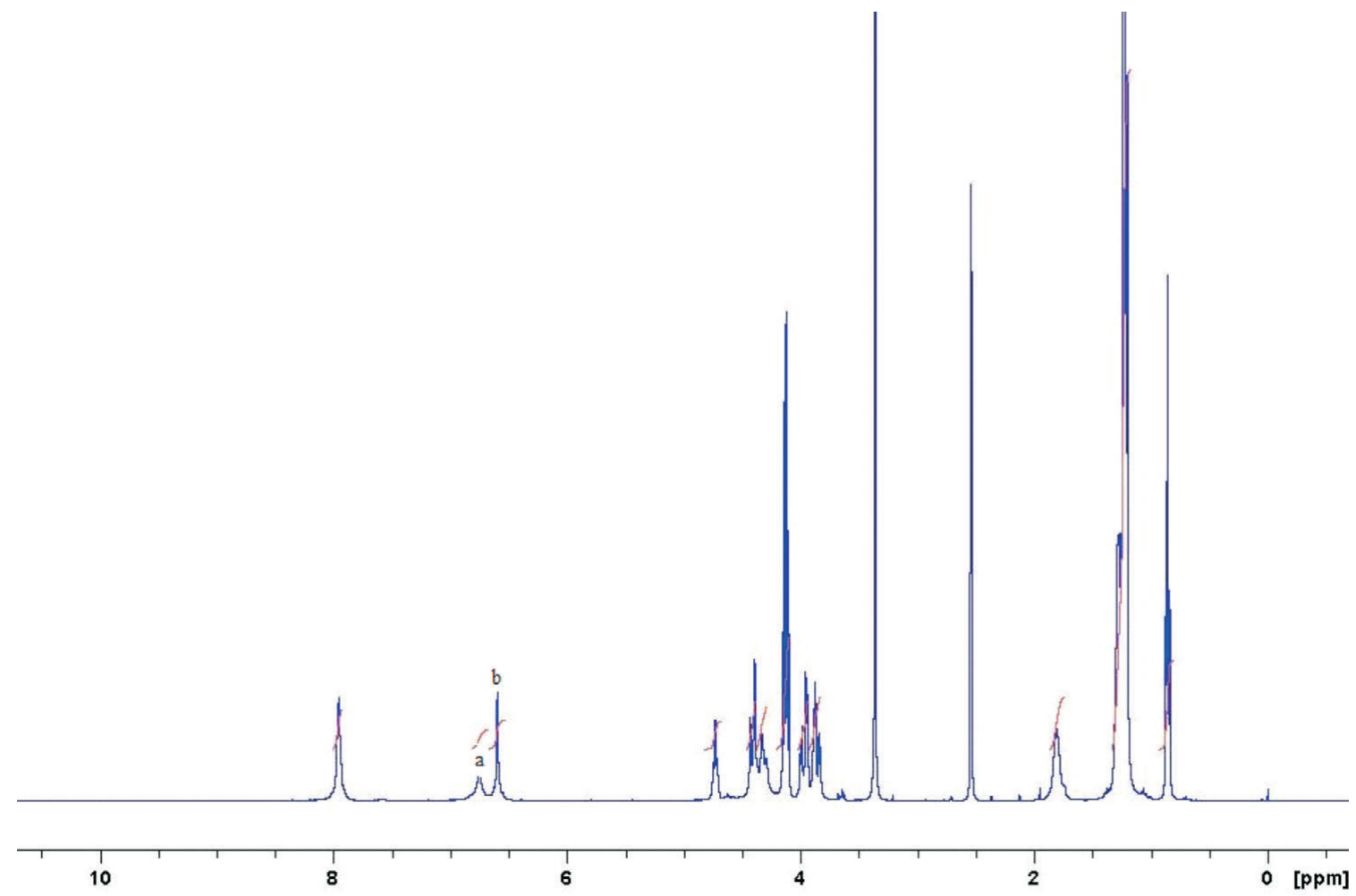

Figure $4{ }^{1} \mathrm{H}$ NMR spectrum of compound $4 a$ in $\mathrm{d}_{6}$-DMSO at room temperature $(400 \mathrm{MHz})$. 


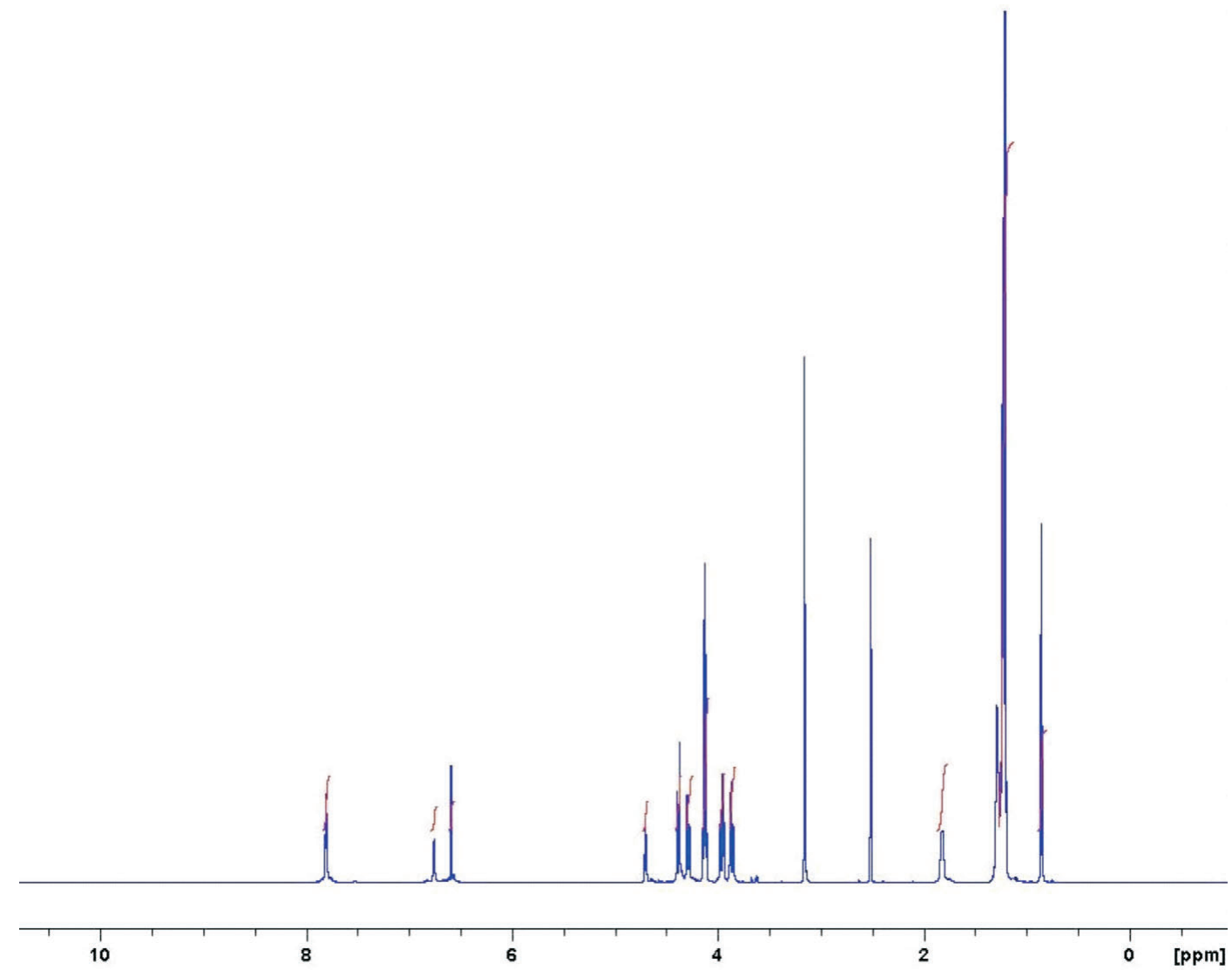

Figure $5{ }^{1} \mathrm{H}$ NMR spectrum of compound $4 a$ in $\mathrm{d}_{6}$-DMSO at $70{ }^{\circ} \mathrm{C}(600 \mathrm{MHz})$.

terminal methyl groups of the 'feet' at $0.84 \mathrm{ppm}$ are coupled to the methylene groups at $1.20-1.28 \mathrm{ppm}$.

Compound $4 \mathrm{~d}$ was synthesized in $72 \%$ yield by reacting L-leucine methyl ester with the octa-acid resorcin[4]arene 3.
Reaction of the octa-acyl chloride resorcin[4]arene 3 with L-proline methyl ester afforded compound $4 \mathrm{e}$ in $69 \%$ yield. The octa-acyl chloride resorcin[4]arene 3 reacted with L-proline methyl ester afforded compound $4 \mathrm{e}$ in $69 \%$ yield. Compound $4 \mathrm{f}$

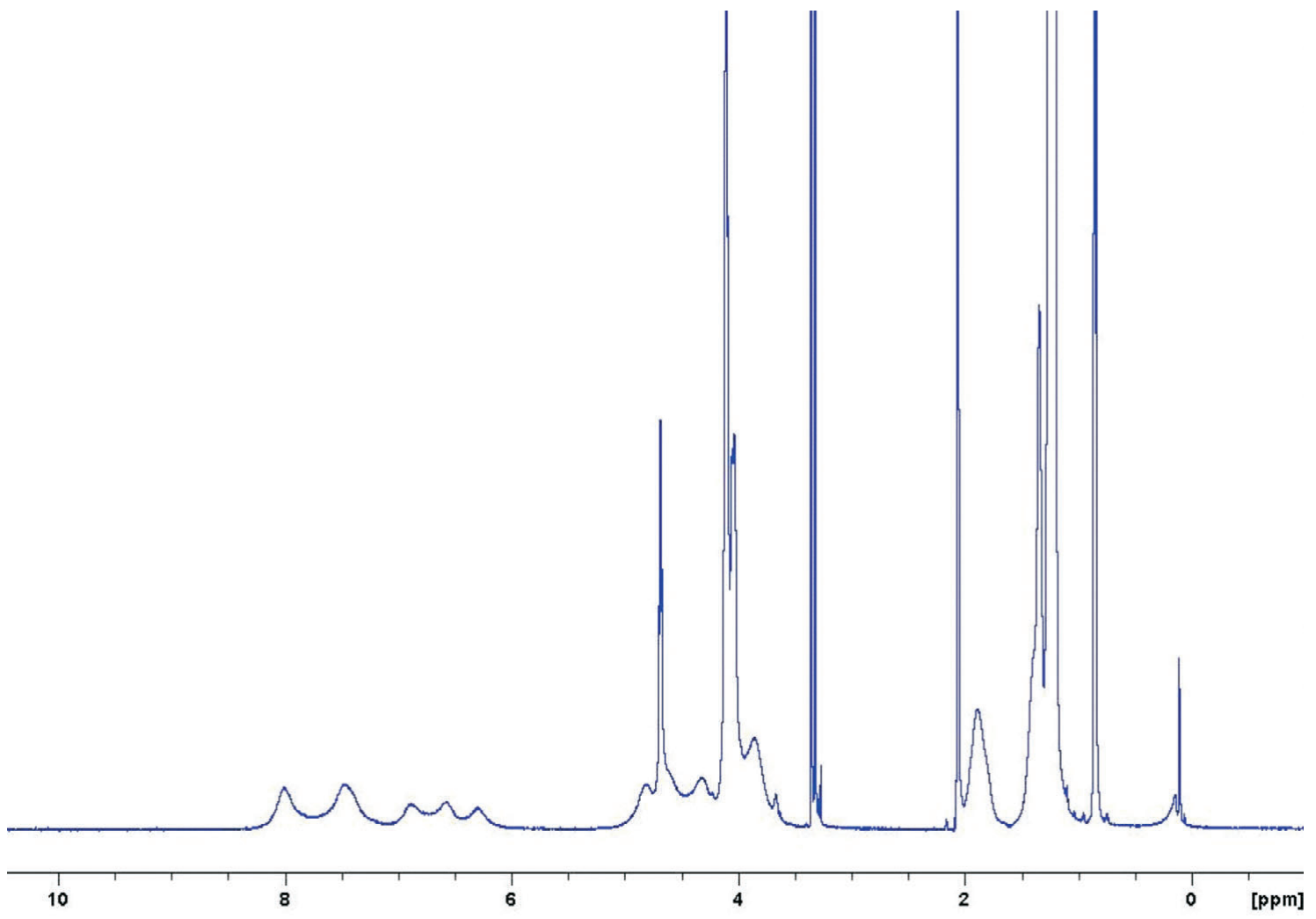

Figure $6{ }^{1} \mathrm{H}$ NMR spectrum of compound $4 a$ in $\mathrm{d}_{6}$-acetone at $-40{ }^{\circ} \mathrm{C}(600 \mathrm{MHz})$. 


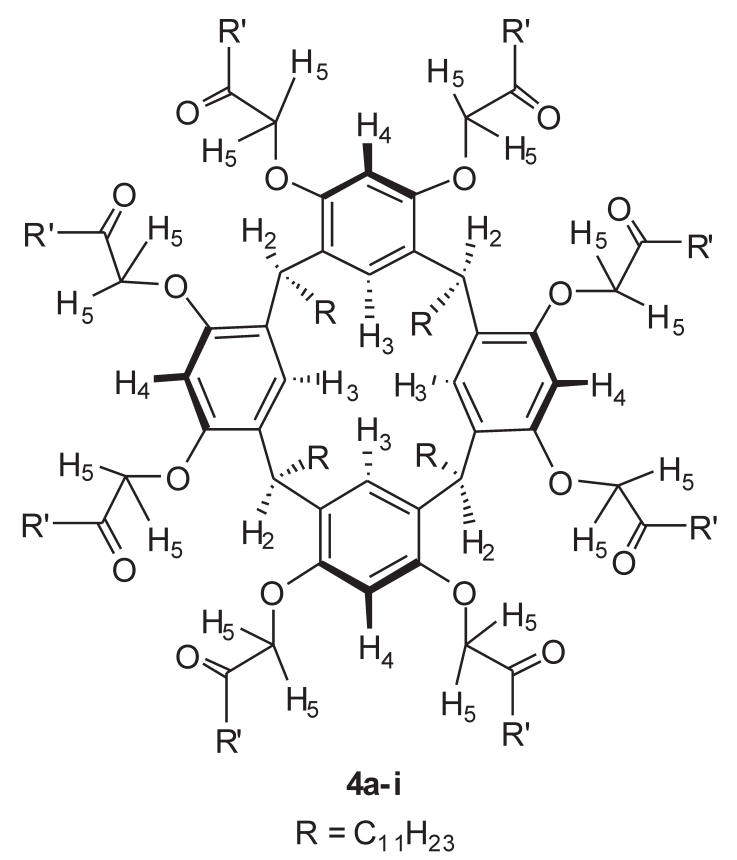

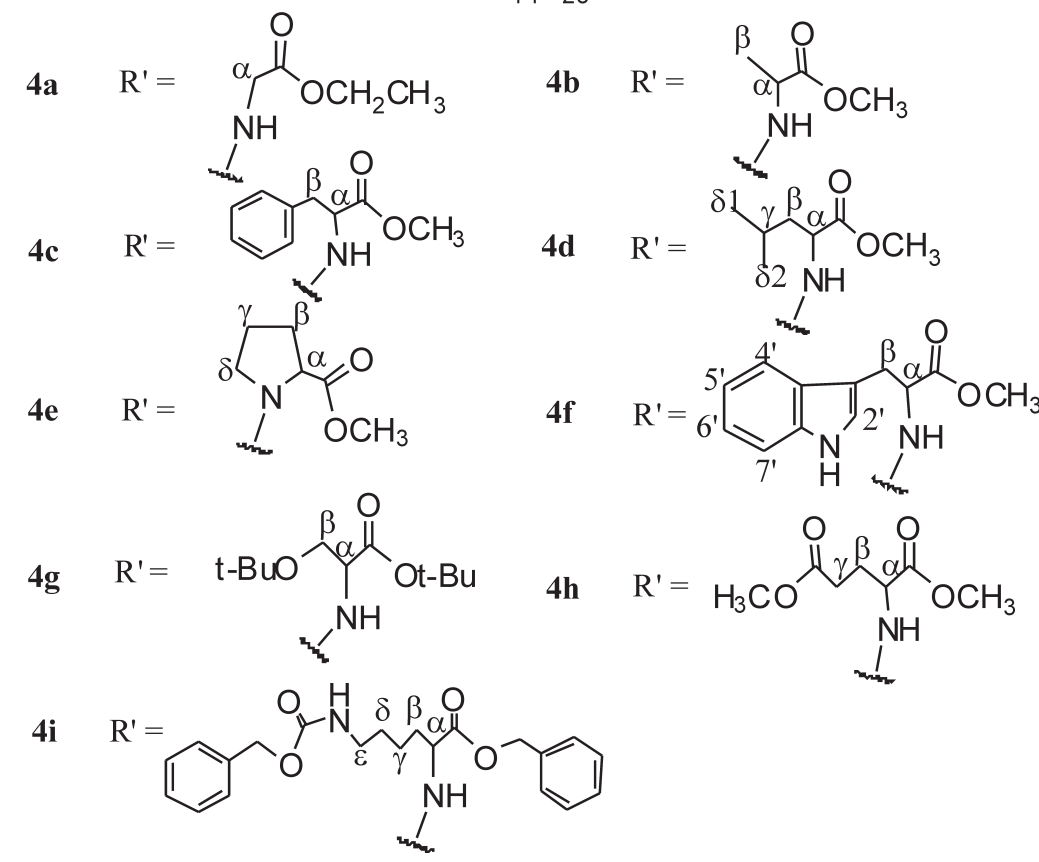

Figure 7 Expanded structure of $\mathbf{4 a - i}$, showing distinctive protons.

was synthesized in $64 \%$ yield by reacting L-tryptophan methyl ester with the octa-acid resorcin[4]arene 3 . The ${ }^{1} \mathrm{H}$ NMR data for compounds $\mathbf{4} \mathbf{d}-\mathbf{f}$ are summarized in Table 2.

Subsequent COSY and HSQC NMR analysis confirmed the presence of the target compounds, showing the expected couplings between the various protons.

Reaction of O-t-butyl-L-serine $t$-butyl ester with the acyl chloride resorcin[4]arene gave compound $4 \mathrm{~g}$ in $59 \%$ yield. Compound $4 \mathrm{~h}$ was synthesized in $60 \%$ yield by reacting L-glutamic acid dimethyl ester with the octa-acid resorcin[4]arene 3 . Compound $4 \mathbf{i}$ was isolated in $67 \%$ yield by reacting $\mathrm{N \varepsilon}$-Cbz-L-lysine benzyl ester with the octa-acid resorcin[4]arene 3 . The ${ }^{1} \mathrm{H}$ NMR

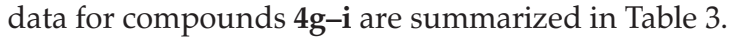

Subsequent COSY and HSQC NMR analysis confirmed the presence of the target compounds, showing the expected couplings between the various protons.

With reference to Fig. 7, the ${ }^{1} \mathrm{H}$ NMR data (Tables 1, 2 and 3) for these compounds clearly demonstrated that: all compounds had characteristic appearance of the amide $\mathrm{NH}$ protons, which appear at a lower frequency indicating the involvement of these protons in intermolecular hydrogen bonding with the water molecules present in the NMR solvent (DMSO), except compound $4 \mathrm{e} .{ }^{17}$ The signal for the diastereotopic methylene protons $\left(\mathrm{H}_{5}\right.$, Fig. 6) appears as a pair of quartets in the ${ }^{1} \mathrm{H}$ NMR spectra for compounds $4 \mathrm{~b}, 4 \mathrm{c}, 4 \mathrm{~d}, 4 \mathrm{f}, 4 \mathrm{~g}, 4 \mathrm{~h}$, and $4 \mathrm{i}$. This splitting can be attributed to the presence of two chiral amino acid units on each aromatic ring ${ }^{15 a, 15 b}$. In compound $4 \mathbf{a}$ where there is no chiral centre, this signal appears as a pair of doublets since the protons are enantiotopic.

The signals for the aromatic protons $\left(\mathrm{H}_{3}\right.$ and $\left.\mathrm{H}_{4}\right)$ appear as two singlets for all compounds. This indicates the symmetric positions of these protons in a crown $\left(C_{4 v}\right)$ conformation at elevated temperature. Therefore, at high temperature, the rate of conformational interchange is high on the NMR timescale and only the signals associated with the crown conformation are observed $^{10 a}$. 


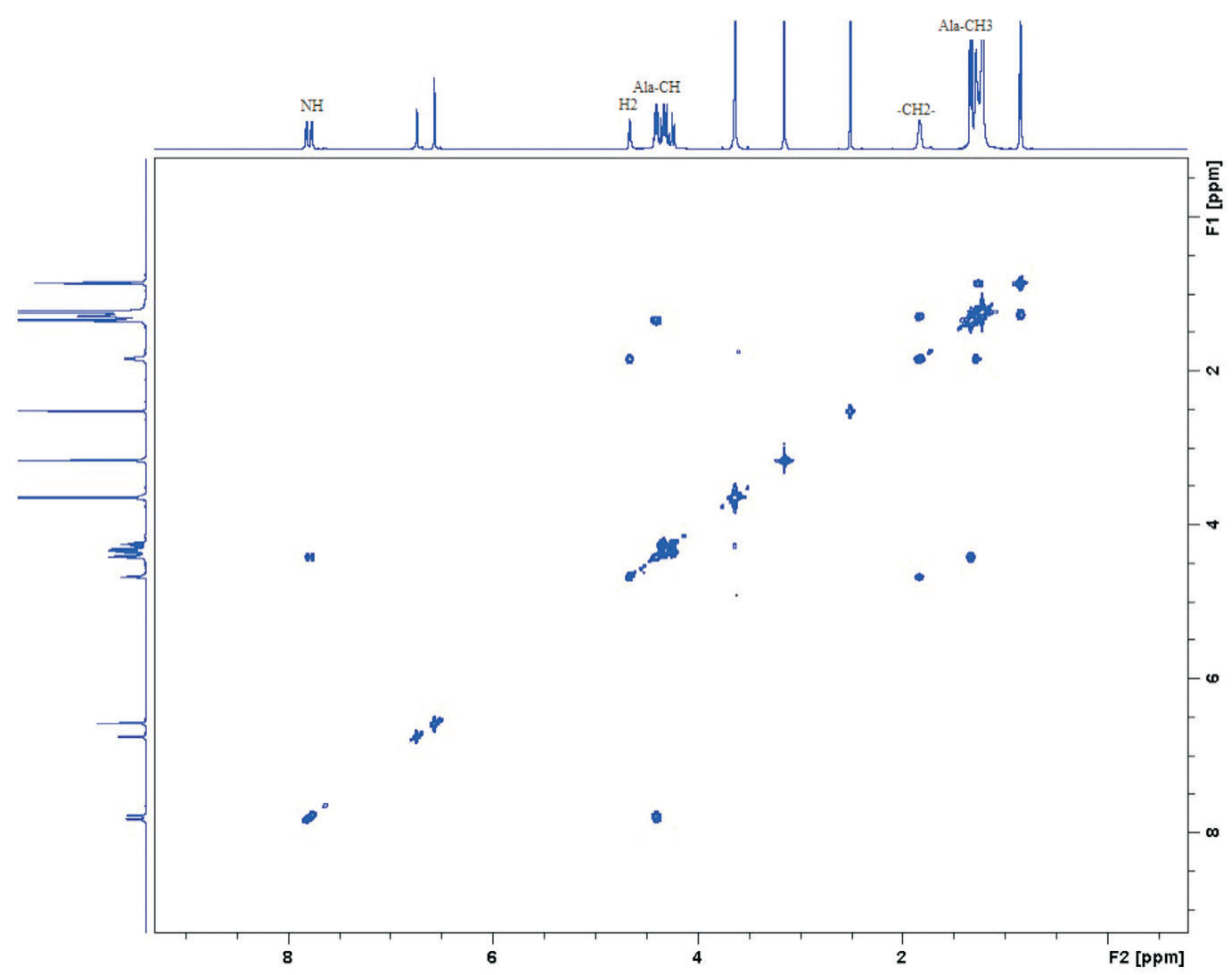

Figure 8 The ${ }^{1} \mathrm{H}-{ }^{1} \mathrm{H}$ COSY spectrum for compound $4 \mathrm{~b}$ in $\mathrm{d}_{6}-\mathrm{DMSO}$ at $70{ }^{\circ} \mathrm{C}(600 \mathrm{MHz})$.

The signal related to the methine protons $\left(\mathrm{H}_{2}\right)$ which bridge the aromatic moieties, appears as a triplet in ${ }^{1} \mathrm{H}$ NMR spectra for these compounds. The signals associated with the undecyl 'feet' remain essentially unchanged in terms of multiplicity and integration. However, these protons have experienced very small changes in terms of chemical shift.

\section{Conclusion}

A series of new resorcin[4]arenes appended with amino acid moieties at the upper rim (4a-i) were synthesized in good yields (59-76 \%). The key step for this synthesis is the amide bond formation between the amine functional group of amino acid units and carboxylic acid group of the octa-acid resorcinarene, 3 . The structure of these octa-substituted resorcinarene derivatives was established on the basis of one and two-dimensional NMR experiments, and confirmed by IR and MS spectra. The ${ }^{1} \mathrm{H} N \mathrm{NR}$ data obtained for the protons related to the aromatic rings of resorcin[4]arene scaffold $\left(\mathrm{H}_{3}\right.$ and $\mathrm{H}_{4}$, Fig. 6) verified that these derivatives adopted stable crown conformations $\left(C_{4 v}\right.$ symmetry) at high temperature. Low temperature NMR experiments confirmed that a boat conformation predominates for these compounds, which is expected for resorcinarenes with eight bulky substituents. These structures are very similar to previously reported ion channel molecules; we presume that they will be capable of ion translocation activity.

\section{Experimental}

Starting materials obtained from commercial suppliers were used without further purification unless otherwise stated. Air- or moisture-sensitive reactions were performed using oven-dried glassware under an inert atmosphere of dry nitrogen. Tetrahydrofuran (THF) was distilled from sodium benzophenoneketyl and dichloromethane was distilled from calcium hydride. Dimethyl sulfoxide (DMSO) and dimethylformamide (DMF) were stored over $4 \AA$ molecular sieves prior to use. Thin layer chromatography (TLC) was performed on aluminium-backed, pre-coated silica gel plates (Merck, silica gel $60 \mathrm{~F}_{254}, 20 \mathrm{~cm} \times$ $20 \mathrm{~cm}$ ). Mobile phases are reported as volume ratios or volume per cent. Compounds were visualized using UV light, $p$-anisaldehyde, or iodine stains. Column chromatography was performed on silica gel 60 (Merck, particle size $0.040-0.063 \mathrm{~mm}$ ). Eluting solvents are reported as volume ratios or volume per cent. Melting points were recorded and are uncorrected. ${ }^{1} \mathrm{H}$ NMR spectra were recorded on a $400 \mathrm{MHz}$ Bruker AVANCE III or $600 \mathrm{MHz}$ BrukerUltrashield spectrometer, the chemical shifts were referenced to the solvent peak, namely $\delta=$ $7.24 \mathrm{ppm}$ for $\mathrm{CDCl}_{3}, \delta=2.50 \mathrm{ppm}$ for $\left(\mathrm{CD}_{3}\right)_{2} \mathrm{SO}$ and $\delta=2.05 \mathrm{ppm}$ for $\left(\mathrm{CD}_{3}\right)_{2} \mathrm{CO}$ at ambient temperature. The ${ }^{1} \mathrm{H}$ NMR spectra were recorded at a transmitter frequency of $600.1 \mathrm{MHz}$ (spectral width, $12335.5 \mathrm{~Hz}$; acquisition time, $1.328 \mathrm{~s}$; $90^{\circ}$ pulse width, $15 \mu \mathrm{s}$; scans, 16; relaxation delay, $1.0 \mathrm{~s}$ ) for the Bruker AVANCE III 600 instrument while the ${ }^{1} \mathrm{H}$ NMR spectra were recorded at a transmitter frequency of $400.2 \mathrm{MHz}$ (spectral width, $8223.7 \mathrm{~Hz}$; acquisition time, $3.98 \mathrm{~s} ; 90^{\circ}$ pulse width, $10 \mu \mathrm{s}$; scans, 16; relaxation delay, $1.0 \mathrm{~s}$ ) for the Brucker AVANCE III 400 instrument. The ${ }^{13} \mathrm{C}$ NMR spectra were recorded at 150.9 $\mathrm{MHz}$ (spectral width, $36057.7 \mathrm{~Hz}$; acquisition time, $0.908 \mathrm{~s}$; $0.908 \mathrm{~s}, 90^{\circ}$ pulse width, $9.00 \mu \mathrm{s}$; scans, 4800 ; relaxation delay, $2.00 \mathrm{~s})$ for the Bruker AVANCE III 600 instrument while the ${ }^{13} \mathrm{C}$ NMR spectra were recorded at $100.6 \mathrm{MHz}$ (spectral width, $24038.5 \mathrm{~Hz}$; acquisition time, $1.363 \mathrm{~s}$; $90^{\circ}$ pulse width, $8.40 \mu \mathrm{s}$, scans, 3200; relaxation delay, $2.00 \mathrm{~s})$ for the Bruker AVANCE III 400 instrument.

The 2D experimental data parameters obtained on the Bruker AVANCE III 400 were as follows: $90^{\circ}$ pulse width, $10 \mu$ s for all spectra, spectral width for ${ }^{1} \mathrm{H}, 3731.3$, 3521.1, 3401.3, 3676.4, 3125.0 and 4065.0, 4065.0, 3731.3, 3546.1 Hz for 4a, 4b, 4c, 4d, 4e, $4 \mathrm{f}, \mathbf{4 g}, \mathbf{4 h}$ and $4 \mathrm{i}$, respectively, (COSY and HSQC) spectral width 
for ${ }^{13} \mathrm{C}, 166670.4 \mathrm{~Hz}$ (HSQC) for $4 \mathbf{a}-\mathbf{i}$, number of data points per spectrum, 2048 (COSY), 1024 (HSQC) for compounds 4a-i; number of time incremental spectra 128 (COSY), 256 (HSQC) for compounds $\mathbf{4} \mathbf{a}-\mathbf{i}$; relaxation delays for compounds for compounds $4 \mathrm{a}, 4 \mathrm{f}, 4 \mathrm{~g}$, $4 \mathrm{~h}$ and $4 \mathrm{i}$ was $1.4 \mathrm{~s}$ and $4 \mathrm{~b}, 4 \mathrm{c}, 4 \mathrm{~d}$ and $4 \mathrm{e}$ was $1.3 \mathrm{~s}$ for COSY experiments while the relaxation delay for HSQC experiments had $1.4 \mathrm{~s}$ for $\mathbf{4 a}-\mathbf{i}$, respectively. Data are reported as positions in parts per million ( $\delta$ in ppm), multiplicity ( $\mathrm{s}=$ singlet, $\mathrm{d}=$ doublet, $\mathrm{dd}=$ double of doublets, $\mathrm{t}=$ triplet, $\mathrm{q}=$ quartet, $\mathrm{m}=$ multiplet, $\mathrm{br}=$ broad $)$, coupling constant $(J$ in $\mathrm{Hz})$ and integration (number of protons). ${ }^{13} \mathrm{C}$ NMR spectra were recorded on a $400 \mathrm{MHz}$ Bruker AVANCE (100 MHz) or $600 \mathrm{MHz}$ Bruker Ultrashield spectrometer $(150 \mathrm{MHz})$. Data are reported as positions in parts per million ( $\delta$ in ppm). Optical rotation data were acquired on a Perkin Elmer Model 341 Polarimeter using a $1 \mathrm{~mL}$ cell with a path length of $100 \mathrm{~mm}$. Infrared (IR) spectra were recorded on a Perkin Elmer spectrum 100 instrument with a universal attenuated total reflection (ATR) attachment at room temperature. Wave numbers are reported in units of $\mathrm{cm}^{-1}$. Mass spectra were recorded using a Burker microTOF-Q II Electron Spray Ionization (ESI) Mass Spectrometer (MS).

\section{Synthesis}

\section{C-undecyl Resorcin[4]arene Octa-ester, $(2)^{13 a, 14}$}

To a stirring suspension of octol 1 (5.52 g, $5.0 \mathrm{mmol})$, ovendried $\left(110{ }^{\circ} \mathrm{C}\right) \mathrm{K}_{2} \mathrm{CO}_{3}(7.6 \mathrm{~g}, 55 \mathrm{mmol})$ and a catalytic amount of sodium iodide $(\mathrm{NaI})$ in dry acetonitrile $\left(\mathrm{CH}_{3} \mathrm{CN}\right)(50 \mathrm{~mL})$ was added methyl-2-bromo acetate $(3.9 \mathrm{~mL}, 40.5 \mathrm{mmol})$. The suspension was refluxed at $82{ }^{\circ} \mathrm{C}$ with stirring under a nitrogen atmosphere for 48 hours. After 24 hours another portion of methyl-2bromoacetate $(3.9 \mathrm{~mL})$ was added. After cooling to room temperature, the mixture was filtered and the filtrate was extracted twice with diethyl ether $(50 \mathrm{~mL})$. The filtrate was concentrated under reduced pressure to give the crude product, which was re-crystallized from dichloromethane-methanol in 1:1 ratio. The precipitate was filtered and washed with methanol to yield the title compound as a white crystal. $(6.5 \mathrm{~g}, 77 \%)$; mp $90-93^{\circ} \mathrm{C}$ [Literature mp $\left.92-94{ }^{\circ} \mathrm{C}\right] ;{ }^{1} \mathrm{HNMR}\left[\mathrm{CDCl}_{3}, 400 \mathrm{MHz}\right]: \delta=6.58(\mathrm{~s}, 4 \mathrm{H}$, $\mathrm{ArH}), 6.20$ (s, $4 \mathrm{H}, \mathrm{ArH}), 4.57$ (t, $4 \mathrm{H}, \mathrm{CH}$ (methine)), $4.30(\mathrm{~s}, 16 \mathrm{H}$, $\left.\mathrm{ArOCH}_{2}\right), 3.77\left(\mathrm{~s}, 24 \mathrm{H}, \mathrm{OCH}_{3}\right), 1.90\left(\mathrm{q}, 8 \mathrm{H}, \mathrm{CH}_{2}\left(\mathrm{CH}_{2}\right)_{9} \mathrm{CH}_{3}\right)$, $1.20-1.30\left(\mathrm{~m}, 72 \mathrm{H}, \mathrm{CH}_{2}\left(\mathrm{CH}_{2}\right)_{9} \mathrm{CH}_{3}\right), 0.87\left(\mathrm{t}, 12 \mathrm{H}, \mathrm{CH}_{3}\right)$ ppm; ${ }^{13} \mathrm{C} \mathrm{NMR}\left[\mathrm{CDCl}_{3}, 100 \mathrm{MHz}\right]: \delta=169.81,154.46,128.51,126.56$, $100.76,67.14,51.91,35.70,34.52,31.93,30.01,29.88,29.79,29.72$ $29.39,28.08,22.69,14.10$ ppm; FT-IR/ATR: 2920, 2851, 1756, 1729, 1610, 1586, 1501, 1436, 1405, 1303, 1210, 1179, 1105, 1082, 979, 903, $850,719,584,527 \mathrm{~cm}^{-1}$.

\section{C-undecyl Resorcin[4]arene Octa-acid (3) $)^{14}$}

To a stirring suspension of $2(6.0 \mathrm{~g}, 3.57 \mathrm{mmol})$ in a mixture of $100 \mathrm{~mL}$ of ethanol and $50 \mathrm{~mL}$ of water was added potassium hydroxide $(5.6 \mathrm{~g}, 99.96 \mathrm{mmol})$. The mixture was refluxed under a nitrogen atmosphere for 3 hours. The resulting mixture was concentrated under reduced pressure. The alkaline solution was acidified with $6 \mathrm{M} \mathrm{HCl}$, and the suspension was extracted with ethyl acetate $(100 \mathrm{~mL} \times 3)$. The combined organic layers were dried over anhydrous $\mathrm{Na}_{2} \mathrm{SO}_{4}$. The solvent was removed in vacuo and the crude product was re-crystallized from methanol/ water in 1:1 ratio. After drying in vacuo the product was obtained as a white solid. $(5.20 \mathrm{~g}, 93 \%)$; mp $183-185^{\circ} \mathrm{C}$ [Literature $\operatorname{mp} 180^{\circ} \mathrm{C}$ ]; ${ }^{1} \mathrm{H}$ NMR [DMSO-d ${ }_{6} 400 \mathrm{MHz}$ ]: $\delta=6.49(\mathrm{~s}, 4 \mathrm{H}, \mathrm{ArH})$, $6.35(\mathrm{~s}, 4 \mathrm{H}, \mathrm{ArH}), 4.48(\mathrm{t}, 4 \mathrm{H}, \mathrm{CH}$ (methine)), $4.41(\mathrm{~d}, 8 \mathrm{H}, \mathrm{J}=$ $\left.16.3 \mathrm{~Hz}, \mathrm{OCH}_{2}-\mathrm{COOH}\right), 4.23\left(\mathrm{~d}, 8 \mathrm{H}, J=16.4 \mathrm{~Hz}, \mathrm{OCH}_{2}-\mathrm{COOH}\right)$, $1.75\left(\mathrm{q}, 8 \mathrm{H}, \mathrm{CH}_{2}\left(\mathrm{CH}_{2}\right)_{9} \mathrm{CH}_{3}\right), 1.20-1.29\left(\mathrm{~m}, 72 \mathrm{H}, \mathrm{CH}_{2}\left(\mathrm{CH}_{2}\right)_{9} \mathrm{CH}_{3}\right)$, 0.82(t, $\left.12 \mathrm{H}, \mathrm{CH}_{3}\right)$ ppm; ${ }^{13} \mathrm{C}$ NMR [DMSO-d $\left.{ }_{6}, 100 \mathrm{MHz}\right]: \delta=$ $170.39,154.00,126.12,125.29,100.02,65.89,38.84,34.93,34.09$, $31.29,29.50,29.25,29.14,29.06,28.73,27.68,22.06,13.85$ ppm; FT-IR/ATR: 3195, 2920, 2850, 1719, 1612, 1587, 1499, 1435, 1407, $1298,1184,1127,1105,1072,905,812,720,665,570 \mathrm{~cm}^{-1}$.

\section{General Procedure for the Synthesis of Amino Acid Resorcin[4] arene Derivatives (4a-i)15}

To a suspension of $3(1.0 \mathrm{~g}, 0.64 \mathrm{mmol})$ in dry $\mathrm{CH}_{2} \mathrm{Cl}_{2}(30 \mathrm{~mL})$ was added freshly distilled oxalyl chloride $(1.1 \mathrm{~mL}, 12.80 \mathrm{mmol})$, and the mixture was refluxed for 18 hours under a nitrogen atmosphere. The unreacted oxalyl chloride and solvent were removed in vacuo, and the product obtained was dried under vacuum for 1 hour. Subsequently, it was dissolved in dry $\mathrm{CH}_{2} \mathrm{Cl}_{2}$ $(20 \mathrm{~mL})$, and slowly added to a cooled solution $\left(0{ }^{\circ} \mathrm{C}\right)$ of amino acid ester hydrochloride $(5.74 \mathrm{mmol})$ and triethyl amine $\left(\mathrm{Et}_{3} \mathrm{~N}\right)$ $(1.35 \mathrm{~mL}, 9.80 \mathrm{mmol})$ in dry $\mathrm{CH}_{2} \mathrm{Cl}_{2}(20 \mathrm{~mL})$. The reaction mixture was allowed to warm up to room temperature and stirred under a nitrogen atmosphere for 18 hours. The solution mixture was treated with $1 \mathrm{M} \mathrm{HCl}(30 \mathrm{~mL})$, and the organic layer was separated, washed with water $(30 \mathrm{~mL})$, and brine $(30 \mathrm{~mL})$. The organic layer was dried over anhydrous $\mathrm{Na}_{2} \mathrm{SO}_{4}$. The solution was filtered, and the solvent was removed under pressure, yielding a sticky residue. The residue obtained was purified on silica gel chromatography using $3 \%$ methanol in chloroform as a mobile phase. The fractions collected were concentrated with a rotary evaporator to give a white gum. These products were triturated with methanol to yield the title compounds as white solids.

\section{Octa-glycine ethyl ester resorcinarene (4a)}

Glycine ethyl ester hydrochloride $(0.80 \mathrm{~g}, 5.74 \mathrm{mmol})$ was used as in the general procedure. The product was obtained as a white solid. $(1.09 \mathrm{~g}, 76 \%), \mathrm{R}_{\mathrm{f}}=0.42\left(3 \% \mathrm{MeOH} / \mathrm{CH}_{3} \mathrm{Cl}\right), \mathrm{mp} 97-100{ }^{\circ} \mathrm{C}$; $\left.{ }^{1} \mathrm{H} \mathrm{NMR} \mathrm{[DMSO}-\mathrm{d}_{6}, 600 \mathrm{MHz}, 70{ }^{\circ} \mathrm{C}\right]: \delta=7.72(\mathrm{t}, J=5.1 \mathrm{~Hz} 8 \mathrm{H}$, $\mathrm{NH}), 6.73(\mathrm{~s}, 4 \mathrm{H}, \mathrm{ArH}), 6.57(\mathrm{~s}, 4 \mathrm{H}, \mathrm{ArH}), 4.69(\mathrm{t}, J=8.0 \mathrm{~Hz} 4 \mathrm{H}, \mathrm{CH}$ (methine)), $4.36\left(\mathrm{~d}, J=14.7 \mathrm{~Hz}, 8 \mathrm{H}, \mathrm{ArOCH}_{2}\right), 4.27(\mathrm{~d}, J=14.7 \mathrm{~Hz}$, $\left.8 \mathrm{H}, \mathrm{ArOCH}_{2}\right), 4.12\left(\mathrm{q}, \mathrm{J}=7.0 \mathrm{~Hz} 16 \mathrm{H}, \mathrm{COOCH}_{2} \mathrm{CH}_{3}\right), 3.96(\mathrm{dd}$, $\left.J=5.1 \mathrm{~Hz} 8 \mathrm{H}, \mathrm{Gly}-\mathrm{CH}_{2}\right), 3.85\left(\mathrm{dd}, J=5.8 \mathrm{~Hz}, 8 \mathrm{H}, \mathrm{Gly}-\mathrm{CH}_{2}\right), 1.81$ $\left(\mathrm{q}, J=6.5 \mathrm{~Hz} 8 \mathrm{H}, \mathrm{CH}_{2}\left(\mathrm{CH}_{2}\right)_{9} \mathrm{CH}_{3}\right), 1.20(\mathrm{t}, J=8.5 \mathrm{~Hz} 24 \mathrm{H}$, $\left.\mathrm{COOCH}_{2} \mathrm{CH}_{3}\right), 1.22-1.27\left(\mathrm{~m}, 72 \mathrm{H}, \mathrm{CH}_{2}\left(\mathrm{CH}_{2}\right)_{9} \mathrm{CH}_{3}\right), 0.84(\mathrm{t}, \mathrm{J}=$ $\left.7.5 \mathrm{~Hz} 12 \mathrm{H}, \mathrm{CH}_{3}\right) \mathrm{ppm}^{13}{ }^{13} \mathrm{CNMR}\left[\mathrm{DMSO}-\mathrm{d}_{6}, 150 \mathrm{MHz}, 70{ }^{\circ} \mathrm{C}\right]: \delta=$ $169.83,168.82,154.16,127.08,126.24,100.84,68.60,60.89,35.27$, $35.14,31.70,29.90,29.55,29.51,29.44,29.10,27.84,22.44,14.41$, 14.19 ppm; FT-IR/ATR: 3414, 2920, 2851, 1757, 1731, 1664, 1586, $1501,1437,1406,1376,1293,1191,1126,1085,1025,904,850,720$, $582 \mathrm{~cm}^{-1}$; MS (ESI-TOF) Calculated for $\mathrm{C}_{120} \mathrm{H}_{184} \mathrm{O}_{32} \mathrm{~N}_{8} \mathrm{Na}$ $[\mathrm{M}+\mathrm{Na}]^{+}: \mathrm{m} / \mathrm{z}=2273.2942$, Found: $m / z=2273.2926$.

\section{Octa-alanine Methyl Ester Resorcinarene (4b)}

L-Alanine methyl ester hydrochloride $(0.80 \mathrm{~g}, 5.74 \mathrm{mmol})$ was used as in the general procedure. The product was obtained as a white solid. (1.05 g, $73 \%) ; \mathrm{R}_{\mathrm{f}}=0.45\left(3 \% \mathrm{MeOH} / \mathrm{CH}_{3} \mathrm{Cl}\right) ; \mathrm{mp}$ 96-99 ${ }^{\circ} \mathrm{C} ;[\alpha]^{20}{ }_{\mathrm{D}}=-9.09\left(c=1.10, \mathrm{CHCl}_{3}\right) ;{ }^{1} \mathrm{H}$ NMR [DMSO-d ${ }_{6}$, $\left.600 \mathrm{MHz}, 70{ }^{\circ} \mathrm{C}\right]: \delta=7.82(\mathrm{~d}, J=7.3 \mathrm{~Hz}, 4 \mathrm{H}, \mathrm{NH}), 7.80(\mathrm{~d}, J=$ $7.3 \mathrm{~Hz}, 4 \mathrm{H}, \mathrm{NH}), 6.73(\mathrm{~s}, 4 \mathrm{H}, \mathrm{ArH}), 6.56(\mathrm{~s}, 4 \mathrm{H}, \mathrm{ArH}), 4.67(\mathrm{t}, J=$ $5.0 \mathrm{~Hz} 4 \mathrm{H}, \mathrm{CH}$ (methine) ), $4.42(\mathrm{q}, J=8.5 \mathrm{~Hz} 8 \mathrm{H}, \mathrm{Ala}-\alpha \mathrm{H}), 4.35$ (q, $\left.J=5.0 \mathrm{~Hz} 8 \mathrm{H}, \mathrm{ArOCH}_{2}\right), 4.24\left(\mathrm{q}, J=5.0 \mathrm{~Hz} 8 \mathrm{H}, \mathrm{ArOCH}_{2}\right), 3.64(\mathrm{~d}$, $\left.J=7.0 \mathrm{~Hz} 24 \mathrm{H}, \mathrm{OCH}_{3}\right), 1.83\left(\mathrm{q}, J=6.5 \mathrm{~Hz} 8 \mathrm{H}, \mathrm{CH}_{2}\left(\mathrm{CH}_{2}\right)_{9} \mathrm{CH}_{3}\right)$, $1.34\left(\mathrm{t}, J=7.2 \mathrm{~Hz} 24 \mathrm{H}\right.$, Ala- $\left.\mathrm{CH}_{3}\right), 1.20-1.28(\mathrm{~m}, 72 \mathrm{H}$, $\left.\mathrm{CH}_{2}\left(\mathrm{CH}_{2}\right)_{9} \mathrm{CH}_{3}\right), 0.84\left(\mathrm{t}, \mathrm{J}=6.0 \mathrm{~Hz} 12 \mathrm{H}, \mathrm{CH}_{3}\right) \mathrm{ppm} ;{ }^{13} \mathrm{C} \mathrm{NMR}$ [DMSO- $\left.\mathrm{d}_{6}, 150 \mathrm{MHz}, 70{ }^{\circ} \mathrm{C}\right]: \delta=172.92,172.84,168.18,168.09$, $154.40,127.19,127.13,126.27,101.43,68.80,68.76,52.27,47.83$, $47.77,35.39,35.13,31.69,29.88,29.50,29.41,29.08,28.09,22.44$, 17.46, 17.43, 14.18 ppm; FT-IR/ATR: 3408, 2923, 2853, 1741, 1676, 
$1613,1568,1521,1499,1436,1345,1293,1211,1157,1107,1055,987$ 905, 851, 756, 720, 634, $541 \mathrm{~cm}^{-1}$; MS (ESI-TOF) Calculated for $\mathrm{C}_{120} \mathrm{H}_{184} \mathrm{O}_{32} \mathrm{~N}_{8} \mathrm{Na}[\mathrm{M}+\mathrm{Na}]^{+}: m / z=2273.2942$, Found: $m / z=$ 2273.2969.

\section{Octa-phenylalanine Methyl Ester Resorcinarene (4c)}

L-Phenylalanine methyl ester hydrochloride $(1.24 \mathrm{~g}, 5.74 \mathrm{mmol})$ was used as in the general procedure. The product was obtained as a white solid. $(1.30 \mathrm{~g}, 71 \%) ; \mathrm{R}_{\mathrm{f}}=0.56\left(3 \% \mathrm{MeOH} / \mathrm{CH}_{3} \mathrm{Cl}\right) ; \mathrm{mp}$ 58-61 ${ }^{\circ} \mathrm{C} ;[\alpha]^{20}{ }_{\mathrm{D}}=+24.24\left(c=1.10, \mathrm{CHCl}_{3}\right) ;{ }^{1} \mathrm{H}$ NMR [DMSO-d ${ }_{6}$ $\left.600 \mathrm{MHz}, 70^{\circ} \mathrm{C}\right]: \mathrm{ddd}=7.77(\mathrm{~d}, J=8.2 \mathrm{~Hz}, 4 \mathrm{H}, \mathrm{NH}), 7.60(\mathrm{~d}, J=$ $8.2 \mathrm{~Hz}, 4 \mathrm{H}, \mathrm{NH}), 7.04-7.15$ (m, $40 \mathrm{H}, \mathrm{Phe}-\mathrm{ArH}), 6.96$ (s, $4 \mathrm{H}, \mathrm{ArH})$, $6.33(\mathrm{~s}, 4 \mathrm{H}, \operatorname{ArH}), 4.64(\mathrm{q}, J=8.0 \mathrm{~Hz} 8 \mathrm{H}$, Phe- $\alpha H), 4.64(\mathrm{t}, J=$ $6.3 \mathrm{~Hz} 4 \mathrm{H}, \mathrm{CH}$ (methine)), $4.28\left(\mathrm{q}, J=7.1 \mathrm{~Hz}, 8 \mathrm{H}, \mathrm{ArOCH}_{2}\right), 4.20$ $\left(\mathrm{q}, J=7.1 \mathrm{~Hz}, 8 \mathrm{H}, \mathrm{ArOCH}_{2}\right), 3.59\left(\mathrm{~d},, J=7.1 \mathrm{~Hz}, 24 \mathrm{H}, \mathrm{OCH}_{3}\right), 3.11$ $\left.(\mathrm{dd}, \mathrm{J}=6.0 \mathrm{~Hz}, 4 \mathrm{H} \text {, Phe-ArCH})_{2}\right) 3.04(\mathrm{dd},, J=6.0 \mathrm{~Hz}, 4 \mathrm{H}$, Phe-ArCH$\left.), 3.03(\mathrm{dd}, J=6.3 \mathrm{~Hz}, 4 \mathrm{H} \text {, Phe-ArCH})_{2}\right), 2.87(\mathrm{dd}, J=$ $6.3 \mathrm{~Hz}, 4 \mathrm{H}$, Phe-ArCH$), 2.17\left(\mathrm{q}, J=7.0 \mathrm{~Hz}, 8 \mathrm{H}, \mathrm{CH}_{2}\left(\mathrm{CH}_{2}\right)_{9} \mathrm{CH}_{3}\right)$, $1.20-1.28\left(\mathrm{~m}, 72 \mathrm{H}, \mathrm{CH}_{2}\left(\mathrm{CH}_{2}\right)_{9} \mathrm{CH}_{3}\right), 0.83(\mathrm{t}, J=6.3 \mathrm{~Hz}, 12 \mathrm{H}$, $\mathrm{CH}_{3}$ ) ppm; ${ }^{13} \mathrm{C}$ NMR [DMSO-d $\left.{ }_{6}, 150 \mathrm{MHz}, 70{ }^{\circ} \mathrm{C}\right]: \delta=171.77$, $171.73,168.32,168.27,154.16,137.27,137.07,129.36,129.33$, $128.67,128.57,128.52,127.07,126.87,126.77,126.35,125.31$, $100.43,68.33,53.59,53.42,52.23,52.20,37.39,37.26,36.07,34.78$, $34.59,31.71,30.95,29.96,29.59,29.52,29.43,29.11,27.86,22.44$, 21.42, 14.17 ppm; FT-IR/ATR: 3411, 3030, 2923, 2853, 1741, 1682, 1607, 1586, 1497, 1436, 1358, 1288, 1192, 1123, 1060, 905, 849, 815, 743, 699, 540, $490 \mathrm{~cm}^{-1}$; MS (ESI-TOF) Calculated for $\mathrm{C}_{168} \mathrm{H}_{216} \mathrm{O}_{32} \mathrm{~N}_{8} \mathrm{Na}[\mathrm{M}+\mathrm{Na}]^{+}: \mathrm{m} / \mathrm{z}=2881.5446$, Found: $\mathrm{m} / \mathrm{z}=$ 2881.7059 .

\section{Octa-leucine Methyl Ester Resorcinarene (4d)}

L-Leucine methyl ester hydrochloride ( $1.04 \mathrm{~g}, 5.74 \mathrm{mmol}$ ) was used as in the general procedure. The product was obtained as a white solid. (1.22 g, $72 \%) ; \mathrm{R}_{\mathrm{f}}=0.56\left(3 \% \mathrm{MeOH} / \mathrm{CH}_{3} \mathrm{Cl}\right) ; \mathrm{mp}$ 61-64 ${ }^{\circ} \mathrm{C} ;[\alpha]_{\mathrm{D}}^{20}=-20.00\left(c=1.05, \mathrm{CHCl}_{3}\right) ;{ }^{1} \mathrm{H}$ NMR [DMSO-d ${ }_{6}$ $\left.600 \mathrm{MHz}, 70{ }^{\circ} \mathrm{C}\right]: \delta=8.02(\mathrm{~d}, J=8.1 \mathrm{~Hz}, 4 \mathrm{H}, \mathrm{NH}), 7.79(\mathrm{~d}, J=$ $8.1 \mathrm{~Hz}, 4 \mathrm{H}, \mathrm{NH}), 6.89(\mathrm{~s}, 4 \mathrm{H}, \mathrm{ArH}), 6.53(\mathrm{~s}, 4 \mathrm{H}, \operatorname{ArH}), 4.77(\mathrm{t}, J=$ $7.5 \mathrm{~Hz}, 4 \mathrm{H}, \mathrm{CH}$ (methine)), $4.47(\mathrm{q}, J=3.56 \mathrm{~Hz}, 8 \mathrm{H}$, Leu- $\alpha H), 4.46$ $\left(\mathrm{q}, J=7.1 \mathrm{~Hz}, 8 \mathrm{H}, \mathrm{ArOCH}_{2}\right), 4.36\left(\mathrm{q}, J=7.6 \mathrm{~Hz}, 8 \mathrm{H}, \mathrm{ArOCH}_{2}\right), 3.62$ $\left(\mathrm{d}, J=17.5 \mathrm{~Hz}, 24 \mathrm{H}, \mathrm{OCH}_{3}\right), 1.81(\mathrm{q}, J=6.7 \mathrm{~Hz}, 8 \mathrm{H}$, $\left.\mathrm{CH}_{2}\left(\mathrm{CH}_{2}\right)_{9} \mathrm{CH}_{3}\right), 1.45-1.67\left(\mathrm{~m}, 24 \mathrm{H}\right.$, Leu-CH and Leu-CH ${ }_{2}$, 1.20-1.28 (m, $\left.72 \mathrm{H}, \mathrm{CH}_{2}\left(\mathrm{CH}_{2}\right)_{9} \mathrm{CH}_{3}\right), 0.87(\mathrm{t}, J=7.5 \mathrm{~Hz}, 24 \mathrm{H}$, Leu- $\left.\mathrm{CH}_{3}\right), 0.84\left(\mathrm{t}, J=7.1 \mathrm{~Hz}, 12 \mathrm{H}, \mathrm{CH}_{3}\right), 0.77(\mathrm{t}, J=7.2 \mathrm{~Hz}, 24 \mathrm{H}$, Leu- $\mathrm{CH}_{3}$ ) ppm; ${ }^{13} \mathrm{C}$ NMR [DMSO- $\left.\mathrm{d}_{6}, 150 \mathrm{MHz}, 70{ }^{\circ} \mathrm{C}\right]: \delta=172.83$, $172.70,168.36,168.27,154.32,154.11,127.38,127.11,126.41$, $100.99,68.81,68.55,52.18,50.42,35.82,34.81,31.68,29.96,29.55$, $29.52,29.50,29.39,29.08,28.05,24.83,24.69,22.98,22.92,22.42$, 21.80, 21.72, 14.15 ppm; FT-IR/ATR: 3415, 2924, 2853, 1742, 1679, $1613,1585,1523,1498,1437,1368,1275,1196,1154,1104,1056$, 985, 902, 827, 721, 546, $466 \mathrm{~cm}^{-1}$; MS (ESI-TOF) Calculated for $\mathrm{C}_{144} \mathrm{H}_{232} \mathrm{O}_{32} \mathrm{~N}_{8} \mathrm{Na}[\mathrm{M}+\mathrm{Na}]^{+}: m / z=2609.3198$, Found: $m / z=$ 2609.3148.

\section{Octa-proline Methyl Ester Resorcinarene (4e)}

L-Proline methyl ester hydrochloride $(0.95 \mathrm{~g}, 1.75 \mathrm{mmol})$, was used as in the general procedure. The product was obtained as a white solid. (1.08 g, $69 \%) ; \mathrm{R}_{\mathrm{f}}=0.43\left(3 \% \mathrm{MeOH} / \mathrm{CH}_{3} \mathrm{Cl}\right) ; \mathrm{mp}$ $65-68{ }^{\circ} \mathrm{C} ;[\alpha]^{20}{ }_{\mathrm{D}}=-80.00\left(c=1.00, \mathrm{CHCl}_{3}\right) ;{ }^{1} \mathrm{H}$ NMR [DMSO-d $\mathrm{d}_{6}$ $\left.600 \mathrm{MHz}, 70^{\circ} \mathrm{C}\right]: \delta=6.82(\mathrm{br} \mathrm{s}, 4 \mathrm{H}, \mathrm{ArH}), 6.38(\mathrm{br} \mathrm{s}, 4 \mathrm{H}, \mathrm{ArH}), 4.68$ $\left(\mathrm{t}, J=7.9 \mathrm{~Hz}, 4 \mathrm{H}, \mathrm{CH}\right.$ (methine)), $4.48\left(\mathrm{br} \mathrm{d}, 16 \mathrm{H}, \mathrm{ArOCH}_{2}\right), 4.38$ $(\mathrm{q}, J=5.66 \mathrm{~Hz}, 8 \mathrm{H}$, Pro- $\alpha H), 3.69\left(\mathrm{~d}, J=7.3 \mathrm{~Hz}, 24 \mathrm{H}, \mathrm{OCH}_{3}\right), 3.56$ $(\mathrm{m}, 16 \mathrm{H}$, Pro- $\delta H), 2.41(\mathrm{~m}, 8 \mathrm{H}$, Pro- $\beta$ H), $2.00-2.15$ (m, $24 \mathrm{H}$, Pro- $\beta$ $H$ and $\gamma H), 1.90\left(\mathrm{q}, J=4.3 \mathrm{~Hz}, 8 \mathrm{H}, \mathrm{CH}_{2}\left(\mathrm{CH}_{2}\right)_{9} \mathrm{CH}_{3}\right), 1.20-1.30(\mathrm{~m}$, $\left.72 \mathrm{H}, \mathrm{CH}_{2}\left(\mathrm{CH}_{2}\right)_{9} \mathrm{CH}_{3}\right), 0.86\left(\mathrm{t}, J=6.5 \mathrm{~Hz}, 12 \mathrm{H}, \mathrm{CH}_{3}\right) \mathrm{ppm} ;{ }^{13} \mathrm{CNMR}$ [DMSO-d $\left.{ }_{6}, 150 \mathrm{MHz}, 70{ }^{\circ} \mathrm{C}\right]: \delta=172.61,167.00,154.85,126.46$,
$99.99,68.91,68.82,59.18,51.95,46.39,41.08,35.87,34.89,31.65$, $29.80,29.50,29.49,29.44,29.37,29.01,28.85,28.00,24.94,22.34$, 14.01 ppm; FT-IR/ATR: 3473, 2923, 2852, 1740, 1645, 1499, 1433, 1343, 1294, 1171, 1126, 1043, 910, 842, 720, 540, $416 \mathrm{~cm}^{-1}$; MS (ESI-TOF) Calculated for $\mathrm{C}_{136} \mathrm{H}_{200} \mathrm{O}_{32} \mathrm{~N}_{8} \mathrm{Na}[\mathrm{M}+\mathrm{Na}]^{+}: \mathrm{m} / \mathrm{z}=$ 2481.4193, Found: $m / z=2481.4062$.

\section{Octa-tryptophan Methyl Ester Resorcinarene (4f)}

L-Tryptophan methyl ester hydrochloride (1.46 g, $5.74 \mathrm{mmol})$, was used as in the general procedure. The product was obtained as a white solid. $(1.29 \mathrm{~g}, 64 \%), \mathrm{R}_{\mathrm{f}}=0.42\left(3 \% \mathrm{MeOH} / \mathrm{CH}_{3} \mathrm{Cl}\right), \mathrm{mp}$ 64-67 ${ }^{\circ} \mathrm{C} ;[\alpha]^{20}{ }_{\mathrm{D}}=+50.00\left(c=1.00, \mathrm{CHCl}_{3}\right) ;{ }^{1} \mathrm{H}$ NMR [DMSO-d ${ }_{6}$ $\left.600 \mathrm{MHz}, 70{ }^{\circ} \mathrm{C}\right]: \delta=10.42$ (s, $4 \mathrm{H}, \mathrm{NH}$-Indole), $10.32(\mathrm{~s}, 4 \mathrm{H}$, $\mathrm{NH}$-Indole), $7.63(\mathrm{~d}, J=7.56 \mathrm{~Hz}, 4 \mathrm{H}, \mathrm{NH}), 7.55(\mathrm{~d}, J=7.68 \mathrm{~Hz}$, $4 \mathrm{H}, \mathrm{NH}), 7.48(\mathrm{t}, J=6.5 \mathrm{~Hz}, 8 \mathrm{H}, H 7-$ Indole $), 7.29(\mathrm{dd}, J=8.10 \mathrm{~Hz}$, $8 \mathrm{H}, \mathrm{H}$ 4-Indole ), 7.02 (t, $J=7.4 \mathrm{~Hz}, 8 \mathrm{H}, \mathrm{H5}$-Indole), 7.00 (t, $J=$ $7.5 \mathrm{~Hz}, 8 \mathrm{H}, \mathrm{H6}$-Indole), 6.90 (s, $8 \mathrm{H}, \mathrm{H2}$-Indole), 6.80 (s, $4 \mathrm{H}, \mathrm{ArH})$, $6.47(\mathrm{~s}, 4 \mathrm{H}, \operatorname{ArH}), 4.71(\mathrm{q}, J=7.1 \mathrm{~Hz}, 8 \mathrm{H}, \operatorname{Trp}-\alpha H), 4.63(\mathrm{t}, J=$ $8.0 \mathrm{~Hz}, 4 \mathrm{H}, \mathrm{CH}$ (methine)), $4.32\left(\mathrm{q}, J=7.0 \mathrm{~Hz}, 8 \mathrm{H}, \mathrm{ArOCH}_{2}\right), 4.26$ $\left(\mathrm{q}, J=7.2 \mathrm{~Hz}, 8 \mathrm{H}, \operatorname{ArOCH}_{2}\right), 3.68\left(\mathrm{~d}, J=6.5 \mathrm{~Hz}, 24 \mathrm{H}, \mathrm{OCH}_{3}\right)$, 3.11-3.25 (m, $16 \mathrm{H}, \operatorname{Trp}-\beta H), 1.83(\mathrm{q}, J=7.7 \mathrm{~Hz}, 8 \mathrm{H}$, $\left.\mathrm{CH}_{2}\left(\mathrm{CH}_{2}\right)_{9} \mathrm{CH}_{3}\right), 1.20-1.28\left(\mathrm{~m}, 72 \mathrm{H}, \mathrm{CH}_{2}\left(\mathrm{CH}_{2}\right)_{9} \mathrm{CH}_{3}\right), 0.85$ (t, $J=$ $6.5 \mathrm{~Hz}, 12 \mathrm{H}, \mathrm{CH}_{3}$ ) ppm; ${ }^{13} \mathrm{C}$ NMR [DMSO-d ${ }_{6}, 150 \mathrm{MHz}, 70{ }^{\circ} \mathrm{C}$ ]: $\delta=172.19,172.14,168.44,168.35,154.46,139.53,136.68,136.65$, $127.67,127.60,125.33,123.97,123.92,121.36,118.86,118.39$, $111.82,111.79,109.68,109.56,101.37,68.85,68.72,53.41,53.28$, $52.12,52.09,35.39,35.26,34.80,31.85,30.96,29.99,29.65,29.53$, $29.44,29.11,28.02,27.87,27.84,22.44,21.42,14.19$ ppm; FT-IR/ATR: 3403, 3056, 2923, 2852, 1738, 1671, 1585, 1496, 1435, $1341,1287,1213,1179,1098,1059,928,860,739,548,424 \mathrm{~cm}^{-1}$; MS (ESI-TOF) Calculated for $\mathrm{C}_{184} \mathrm{H}_{224} \mathrm{O}_{32} \mathrm{~N}_{16} \mathrm{Na}[\mathrm{M}+\mathrm{Na}]^{+}: \mathrm{m} / \mathrm{z}=$ 3194.6348, Found: $m / z=3194.6451$.

\section{Octa-serine (O-t-butyl) $t$-Butyl Ester Resorcinarene (4g)}

O-t-Butyl-L-serine $t$-butyl hydrochloride $(1.46 \mathrm{~g}, 5.74 \mathrm{mmol}$ ), was used in the general method. The product was obtained as a white solid. (1.19 g, $59 \%), \mathrm{R}_{\mathrm{f}}=0.62\left(3 \% \mathrm{MeOH} / \mathrm{CH}_{3} \mathrm{Cl}\right), \mathrm{mp}$ $56-59^{\circ} \mathrm{C} ;[\alpha]^{20}{ }_{\mathrm{D}}=+20.00\left(c=1.00, \mathrm{CHCl}_{3}\right) ;{ }^{1} \mathrm{H}$ NMR [DMSO-d ${ }_{6}$, $\left.600 \mathrm{MHz}, 70^{\circ} \mathrm{C}\right]: \delta=7.27(\mathrm{~d}, J=8.2 \mathrm{~Hz}, 4 \mathrm{H}, \mathrm{NH}), 7.24(\mathrm{~d}, J=$ $8.1 \mathrm{~Hz}, 4 \mathrm{H}, \mathrm{NH}), 6.73(\mathrm{~s}, 4 \mathrm{H}, \operatorname{ArH}), 6.53(\mathrm{~s}, 4 \mathrm{H}, \operatorname{ArH}), 4.63(\mathrm{t}, J=$ $8.0 \mathrm{~Hz}, 4 \mathrm{H}, \mathrm{CH}$ (methine) ), $4.46(\mathrm{q}, J=5.72 \mathrm{~Hz}, 8 \mathrm{H}$, Ser- $\alpha H), 4.36$ $\left(\mathrm{d}, J=14.70 \mathrm{~Hz}, 4 \mathrm{H}, \mathrm{ArOCH}_{2}\right), 4.28(\mathrm{~d}, J=14.94 \mathrm{~Hz}, 4 \mathrm{H}$, $\left.\mathrm{ArOCH}_{2}\right), 4.25\left(\mathrm{~d}, J=14.88 \mathrm{~Hz}, 4 \mathrm{H}, \mathrm{ArOCH}_{2}\right), 4.18(\mathrm{~d}, J=$ $\left.14.82 \mathrm{~Hz}, 4 \mathrm{H}, \mathrm{ArOCH}_{2}\right), 3.70\left(\mathrm{dd}, J=3.1 \mathrm{~Hz}, 8 \mathrm{H}, \mathrm{Ser}-\beta \mathrm{CH}_{2}\right), 3.54$ $\left(\mathrm{dd}, J=4.6 \mathrm{~Hz}, 8 \mathrm{H}\right.$, Ser $\left.\beta \mathrm{CH}_{2}\right), 1.86(\mathrm{q}, J=6.4 \mathrm{~Hz}, 8 \mathrm{H}$, $\left.\mathrm{CH}_{2}\left(\mathrm{CH}_{2}\right)_{9} \mathrm{CH}_{3}\right), 1.40(\mathrm{~d}, \mathrm{~J}=3.5 \mathrm{~Hz}, 72 \mathrm{H}$, Ser-t-But $), 1.20-1.28(\mathrm{~m}$, $\left.72 \mathrm{H}, \mathrm{CH}_{2}\left(\mathrm{CH}_{2}\right)_{9} \mathrm{CH}_{3}\right), 1.09(\mathrm{~d}, J=3.8 \mathrm{~Hz}, 72 \mathrm{H}$, Ser-t-But), $0.86(\mathrm{t}$, $\left.J=6.5 \mathrm{~Hz}, 12 \mathrm{H}, \mathrm{CH}_{3}\right) \mathrm{ppm} ;{ }^{13} \mathrm{CNMR}\left[\mathrm{DMSO}-\mathrm{d}_{6}, 150 \mathrm{MHz}, 70^{\circ} \mathrm{C}\right]$ : $\delta$ 169.19, 168.22, 168.00, 154.69, 154.46, 154.39, 127.69, 127.58, $126.40,101.57,81.44,81.35,81.33,73.12,73.06,73.03,69.43,69.04$, $62.37,62.28,53.46,53.40,53.32, .35 .72,35.25,31.61,30.70,29.58$, $29.49,29.44,29.32,29.00,27.89,22.33,22.31,14.01$ ppm; FT-IR/ATR: 3430, 2973, 2926, 2855, 1738, 1684, 1587, 1500, 1468, 1365, 1293, 1247, 1192, 1147, 1098, 1058, 989, 906, 877, 848, 736, 646, $566 \mathrm{~cm}^{-1}$; MS (ESI-TOF) Calculated for $\mathrm{C}_{176} \mathrm{H}_{296} \mathrm{O}_{40} \mathrm{~N}_{8} \mathrm{Na}$ $[\mathrm{M}+\mathrm{Na}]^{+}: m / z=3187.1331$, Found: $m / z=3187.1433$.

\section{Octa-gulatmicacid (O -methoxy) Methyl Ester Resorcinarene (4h)}

L-Glutamic acid dimethyl ester hydrochloride (1.22 g, $5.74 \mathrm{mmol})$, was used as in the general method. The product was obtained as a white solid. $(1.10 \mathrm{~g}, 60 \%), \mathrm{R}_{\mathrm{f}}=0.46(3 \%$ $\left.\mathrm{MeOH} / \mathrm{CH}_{3} \mathrm{Cl}\right), \operatorname{mp} 54-57^{\circ} \mathrm{C} ;[\alpha]^{20}{ }_{\mathrm{D}}=-10.00\left(\mathrm{c}=1.00, \mathrm{CHCl}_{3}\right)$; ${ }^{1} \mathrm{H}$ NMR [DMSO-d $\left.{ }_{6}, 600 \mathrm{MHz}, 70{ }^{\circ} \mathrm{C}\right]: \delta=7.66(\mathrm{~d} \mathrm{~d}, J=7.4 \mathrm{~Hz}$, $8 \mathrm{H}, \mathrm{NH}), 6.81(\mathrm{~s}, 4 \mathrm{H}, \mathrm{ArH}), 6.55(\mathrm{~s}, 4 \mathrm{H}, \mathrm{ArH}), 4.69(\mathrm{t}, J=7.2 \mathrm{~Hz}$, 
$4 \mathrm{H}, \mathrm{CH}$ (methine)), $4.44(\mathrm{q}, J=8.56 \mathrm{~Hz}, 8 \mathrm{H}, \mathrm{Glu}-\alpha \mathrm{H}), 4.32(\mathrm{q}, J=$ $\left.8.56 \mathrm{~Hz}, 8 \mathrm{H}, \mathrm{ArOCH}_{2}\right), 4.30\left(\mathrm{q}, J=7.9 \mathrm{~Hz}, 8 \mathrm{H}, \mathrm{ArOCH}_{2}\right), 3.70$ ( s, $\left.24 \mathrm{H}, \mathrm{OCH}_{3}\right), 3.58\left(\mathrm{~d}, J=3.81 \mathrm{~Hz}, 24 \mathrm{H}, \mathrm{OCH}_{3}\right), 2.36(\mathrm{q}, J=$ $4.2 \mathrm{~Hz}, 16 \mathrm{H}$, Glu- $\gamma$ H), 2.13 (m, 8 H, Glu- $\beta$ H), 1.96 (m, 8 H, Glu- $\beta$ $H), 1.86\left(\mathrm{q}, J=5.1 \mathrm{~Hz}, 8 \mathrm{H}, \mathrm{CH}_{2}\left(\mathrm{CH}_{2}\right)_{9} \mathrm{CH}_{3}\right), 1.20-1.29(\mathrm{~m}, 72 \mathrm{H}$, $\left.\mathrm{CH}_{2}\left(\mathrm{CH}_{2}\right)_{9} \mathrm{CH}_{3}\right), 0.87\left(\mathrm{t}, \mathrm{J}=6.5 \mathrm{~Hz}, 12 \mathrm{H}, \mathrm{CH}_{3}\right) \mathrm{ppm} ;{ }^{13} \mathrm{C} \mathrm{NMR}$ [DMSO-d $\left.{ }_{6}, 150 \mathrm{MHz}, 70{ }^{\circ} \mathrm{C}\right]: \delta=172.89,172.87,171.97,171.93$, $168.59,154.47,154.37,127.26,126.38,101,26,68.86,68.65,52.33$, $52.32,51.65,51.62,51.45,51.40,35.11,31.69,30.12,30.01,29.95$, $29.58,29.51,29.42,29.09,28.02,26.74,26.70,22.44,14.18$ ppm; FT-IR/ATR: 3408, 2924, 2853, 1736, 1680, 1585, 1522, 1499, 1436, $1369,1293,1194,1170,1126,1056,985,901,824,721,638,556 \mathrm{~cm}^{-1}$; MS (ESI-TOF) Calculated for $\mathrm{C}_{144} \mathrm{H}_{216} \mathrm{O}_{48} \mathrm{~N}_{8} \mathrm{Na}[\mathrm{M}+\mathrm{Na}]^{+}: \mathrm{m} / z=$ 2849.4632, Found: $m / z=2849.4642$.

Octa-lysine (N\&-benzyloxyl) Benzyl Ester Resorcinarene (4i)

$\mathrm{N} \varepsilon$-Cbz-L-lysine benzyl ester hydrochloride (2.34 g, 5.74 $\mathrm{mmol}$ ), was used as in the general procedure. The product was obtained as a white solid. (1.88 g, $67 \%), \mathrm{R}_{\mathrm{f}}=0.52(3 \%$ $\left.\mathrm{MeOH} / \mathrm{CH}_{3} \mathrm{Cl}\right)$, mp 57-60 ${ }^{\circ} \mathrm{C} ;[\alpha]^{20}{ }_{\mathrm{D}}=+7.69\left(c=1.26, \mathrm{CHCl}_{3}\right)$; ${ }^{1} \mathrm{H}$ NMR [DMSO-d $\left.{ }_{6}, 600 \mathrm{MHz}, 70{ }^{\circ} \mathrm{C}\right]: \delta=7.61(\mathrm{dd}, J=7.8 \mathrm{~Hz}$, $8 \mathrm{H}, \mathrm{NH}), 7.26-7.36$ (m, $80 \mathrm{H}$, Lys-ArH), 6.84 (s, 4 H, ArH) , 6.61 (br $\mathrm{t}, 8 \mathrm{H}$, Lys- $\varepsilon \mathrm{NH}), 6.59(\mathrm{~s}, 4 \mathrm{H}, \mathrm{ArH}), 5.13\left(\mathrm{~m}, 16 \mathrm{H}\right.$, Lys-cbz-CH$-\mathrm{H}_{2} \mathrm{O}$, $4.77\left(\mathrm{~s}, 16 \mathrm{H}\right.$, Lys-Bn- $\mathrm{CH}_{2} \mathrm{O}$,), $4.68(\mathrm{t}, \mathrm{J}=7.2 \mathrm{~Hz}, 4 \mathrm{H}, \mathrm{CH}$ (methine)), $4.44(\mathrm{q}, J=6.1 \mathrm{~Hz}, 8 \mathrm{H}$, Lys- $\alpha H), 4.35(\mathrm{q}, J=8.42 \mathrm{~Hz}$, $\left.8 \mathrm{H}, \mathrm{ArOCH}_{2}\right), 4.27\left(\mathrm{q}, J=8.0 \mathrm{~Hz}, 8 \mathrm{H}, \mathrm{ArOCH}_{2}\right), 3.10(\mathrm{q}, \mathrm{J}=5.2 \mathrm{~Hz}$, $16 \mathrm{H}$, Lys- $\left.\varepsilon \mathrm{CH}_{2}\right), 1.86\left(\mathrm{q}, \mathrm{J}=6.8 \mathrm{~Hz}, 8 \mathrm{H}, \mathrm{CH}_{2}\left(\mathrm{CH}_{2}\right)_{9} \mathrm{CH}_{3}\right), 1.82(\mathrm{~m}$, $8 \mathrm{H}$, Lys- $\left.\beta \mathrm{CH}_{2}\right), 1.78\left(\mathrm{~m}, 8 \mathrm{H}\right.$, Lys- $\left.\beta \mathrm{CH}_{2}\right), 1.39\left(\mathrm{~m}, 16 \mathrm{H}\right.$, Lys- $\left.\delta \mathrm{CH}_{2}\right)$, $1.39\left(\mathrm{~m}, 16 \mathrm{H}\right.$, Lys- $\left.\gamma \mathrm{CH}_{2}\right), 1.20-1.28\left(\mathrm{~m}, 72 \mathrm{H}, \mathrm{CH}_{2}\left(\mathrm{CH}_{2}\right)_{9} \mathrm{CH}_{3}\right), 0.80$ $\left(\mathrm{t}, J=6.7 \mathrm{~Hz}, 12 \mathrm{H}, \mathrm{CH}_{3}\right) \mathrm{ppm},{ }^{13} \mathrm{C}$ NMR $\left[\mathrm{DMSO}-\mathrm{d}_{6}, 150 \mathrm{MHz}\right.$, $\left.70{ }^{\circ} \mathrm{C}\right]: \delta=171.84,171.82,168.52,168.44,156.50,154.76,154.66$, $137.87,136.32,136.29,128.80,128.42,128.33,128.13,128.12$, $127.96,127.71,126.49,125.29,101.92,69.35,69.14,66.63,66.60$, $65.73,52.43,52.40,49.05,35.51,34.75,31.63,31.55,31.02,29.99$ $29.58,29.50,29.46,29.39,29.02,28.05,22.99,22.33,14.00$ ppm; FT-IR/ATR: 3324, 3064, 3033, 2924, 2854, 1682, 1585, 1521, 1498, 1455, 1345, 1244, 1177, 1128, 1055, 1027, 910, 824, 735, 695, 576, $458 \mathrm{~cm}^{-1}$; MS (ESI-TOF) Calculated for $\mathrm{C}_{256} \mathrm{H}_{320} \mathrm{O}_{48} \mathrm{~N}_{16} \mathrm{Na}$ $[\mathrm{M}+\mathrm{Na}]^{+1 / 2}: m / z=2217.1575$, Found: $m / z=2217.1494$.

\section{Supplementary material}

The proton and carbon NMR data can be found in the online supplement.

\section{Acknowledgements}

We thank UKZN and NRF for funding of this project.

\section{References}

1 a) A.G.S. Hoegberg, Two stereoisomeric macrocyclic resorcinolacetaldehyde condensation products, J. Org. Chem., 1980, 45, 4498-4500; b) L.M. Tunstad, J.A. Tucker, E. Dalcanale, J. Weiser, J.A Bryant, J. C. Sherman, R.C. Helgeson, C.B. Knobler and D. J. Cram Host guest complexation. 48. Octol building-blocks for cavitands and carcerands, J. Org. Chem., 1989, 54, 1305-1312; c) E.U.T. Vanvelzen, J.F.J. Engbersen and D.N. Reinhoudt, Self-assembled monolayers of receptor adsorbates on gold - Preparation and characterization, J. Am. Chem. Soc., 1994, 116, 3597-3598.

2 a) C. Naumann, E. Roman, C. Peinador, T. Ren, B.O. Patrick, A.E. Kaifer and J.C. Sherman, Expanding cavitand chemistry: the preparation and characterization of $\mathrm{n}$ cavitands with $\mathrm{n}>=4$, Chem. Eur. J., 2001, 7, 1637-1645; b) K. Misztal, A. Sartori, R. Pinalli, C. Massera and E. Dalcanale, Design and synthesis of a cavitand pillar for MOFs, Supramol. Chem., 2014, 26, 151-156.

3 a) A. J. Wright, S.E. Matthews, W.B. Fischer and P.D. Beer, Novel resorcin 4 arenes as potassium-selective ion-channel and transporter mimics, Chem. Eur. J., 2001, 7, 3474-3481; b) E.K. Kazakova, A.V. Prosvirkin, V.V. Yanilkin, R. Froehlich and W.D. Habicher, A novel and effective strategy for the construction of "tube-like" double resorcin 4 arenes, J. Inclusion Phenom., 2003, 47, 149-153; c) P. Ogirala,
S. Negin, C. Agena, C. Schaefer, T. Geisler, J. Mattay and G.W. Gokel, Properties of long alkyl-chained resorcin 4 arenes in bilayers and on the Langmuir trough, New J. Chem., 2013, 37, 105-111.

4 a) D.J. Cram, J.M. Cram, Container Molecules and Their Guests, Vol. 4, Royal Society of Chemistry, Cambridge, 1994; b) P. Timmerman, W. Verboom and D.N. Reinhoudt, Resorcinarenes, Tetrahedron, 1996, 52, 2663-2704.

5 a) B. Botta, M. Cassani, I.D'Acquarica, D. Subissati, G. Zappia and G. Delle Monache, Resorcarenes: hollow building blocks for the host-guest chemistry, Curr. Org. Chem., 2005, 9, 1167-1202; b) W. Iwanek, A. Wzorek, Introduction to the chirality of resorcinarenes, Mini-Rev. Org. Chem., 2009, 6, 398-411.

6 A. Casnati, F. Sansone and R. Ungaro, Peptido- and glycocalixarenes: playing with hydrogen bonds around hydrophobic cavities, Acc. Chem. Res., 2003, 36, 246-254.

7 a) I. Elidrisi, S. Negin, P.V. Bhatt, T. Govender, H.G. Kruger, G.W. Gokel and G.E.M. Maguire, Pore formation in phospholipid bilayers by amphiphilic cavitands, OBC, 2011, 9, 4498-4506; b) I. Elidrisi, P.V. Bhatt, T. Govender, H.G. Kruger and G.E.M. Maguire, Synthesis and NMR elucidation of novel amino acid cavitand derivatives, Tetrahedron, 2014, 70, 7057-7066.

8 a) W. Iwanek, M. Urbaniak, B. Gawdzik and V. Schurig, Synthesis of enantiomerically and diastereomerically pure oxazaborolobenzoxazaborininone derivatives of resorcinarene from L-proline, Tetrahedron: Asymmetry, 2003, 14, 2787-2792; b) P. Shahgaldian, U. Pieles and M. Hegner, Enantioselective recognition of phenylalanine by a chiral amphiphilic macrocycle at the air-water interface: a copper-mediated mechanism, Langmuir, 2005, 21, 6503-6507; c) C.F. Dignam, J.J. Zopf, C.J. Richards and T.J. Wenzel, Water-soluble calix 4 resorcarenes as enantioselective NMR shift reagents for aromatic compounds, J. Org. Chem., 2005, 70, 8071-8078.

9 B. Botta, M. Botta, A. Filippi, A. Tafi, G. Delle Monache and M. Speranza, Enantioselective guest exchange in a chiral resorcin 4 arene cavity, J. Am. Chem. Soc., 2002, 124, 7658-7659.

10 a) L. Abis, E. Dalcanale, A. Duvosel and S. Spera, Structurally new macrocycles from the resorcinol aldehyde condensation - Configurational and conformational-analyses by means of dynamic NMR, NOE, and T1 experiments, J. Org. Chem., 1988, 53, 5475-5479; b) Y. Aoyama, Y. Tanaka and S. Sugahara, Molecular recognition. 5. Molecular recognition of sugars via hydrogen-bonding interaction with a synthetic polyhydroxy macrocycle, J. Am. Chem. Soc., 1989, 111, 5397-5404.

11 a) M.M. Conn and J. Rebek, Self-assembling capsules, Chem. Rev., 1997, 97, 1647-1668;b) D.M. Rudkevich and J. Rebek, Deepening cavitands, Eur. J. Org. Chem., 1999, 1991-2005; c) W. Sliwa and J. Peszke, Chemistry of cavitands, Mini-Rev. Org. Chem., 2007, 4, 125-142.

12 a) T. Fujimoto, C. Shimizu, O. Hayashida and Y. Aoyama, Solutionto-surface molecular-delivery system using a macrocyclic sugar cluster. Sugar-directed adsorption of guests in water on polar solid surfaces, J. Am. Chem. Soc., 1997, 119, 6676-6677; b) T. Fujimoto, C. Shimizu, O. Hayashida and Y. Aoyama, Ternary complexation involving protein. Molecular transport to saccharide-binding proteins using macrocyclic saccharide cluster as specific transporter, J. Am. Chem. Soc., 1998, 120, 601-602; c) O. Hayashida, M. Kato, K. Akagi and Y. Aoyama, Interaction of sugar and anion in water via hydrogen bonding: Chain-length dependent agglutination of oligosaccharide clusters induced by multivalent anion binding, J. Am. Chem. Soc., 1999, 121, 11597-11598;d) O. Hayashida, J. Ito, S. Matsumoto and I. Hamachi, Preparation and unique circular dichroism phenomena of urea-functionalized self-folding resorcinarenes bearing chiral termini through asymmetric hydrogen-bonding belts, OBC, 2005, 3, 654-660.

13 a) J.R. Fransen and P.J. Dutton, Cation binding and conformation of octafunotionalized calix 4 resorcinarenes, Can. J. Chem., 1995, 73, 2217-2223; b) V.K. Jain, S.G. Pillai, R.A. Pandya, Y.K. Agrawal and P.S. Shrivastav, Molecular octopus: octa functionalized calix 4 resorcinarene-hydroxamic acid C4RAHA for selective extraction, separation and preconcentration of U(VI), Talanta, 2005, 65, 466-475.

14 A. Bazzanella, H. Morbel, K. Bachmann, R. Milbradt, V. Bohmer and W. Vogt, Highly efficient separation of amines by electrokinetic chromatography using resorcarene-octacarboxylic acids as pseudostationary phases, J. Chromatogr. A, 1997, 792, 143-149.

15 a) F. Sansone, S. Barboso, A. Casnati, M. Fabbi, A. Pochini, F. Ugozzoli 
S. Afr. J. Chem., 2015, 68, 27-38,

$<$ http://journals.sabinet.co.za/sajchem/>.

and R. Ungaro, Synthesis and structure of chiral cone calix 4 arenes functionalized at the upper rim with L-alanine units, Eur. J. Oro Chem., 1998, 897-905; b) L. Frkanec, A. Visnjevac, B. Kojic-Prodic and M. Zinic, Calix 4 arene amino acid derivatives. Intra- and intermolecular hydrogen-bonded organization in solution and the solid state, Chem. Eur. J., 2000, 6, 442-453; c) M. Ree, J.S. Kim, J.J. Kim, B.H. $\mathrm{Kim}, \mathrm{J}$. Yoon and H. Kim, Cavitands bearing four fluorophores, Tetrahedron Lett., 2003, 44, 8211-8215.

16 a) A.G.S. Hogberg, Stereoselective synthesis and DNMR study of 2
1,8,15-22-Tetraphenyl 14 Metacyclophan-3,5,10,12,17,19,24,26Octols, J. Am. Chem. Soc., 1980, 102, 6046-6050;b) S. Strandman, M. Luostarinen, K. Niemela, H. Tenhu and K. Rissanen, Resorcinarenebased ATRP initiators for star polymers, J. Polym. Sci., Part A: Polym. Chem., 2004, 42, 4189-4201.

17 B.C. Gibb, A.R. Mezo, A.S. Causton, J.R. Fraser, F.C.S. Tsai and J.C. Sherman, Efficient coupling of amino-acid derivatives to rigid organic scaffolds - Model syntheses for de-novo proteins, Tetrahedron, 1995, 51, 8719-8732. 


\section{Supporting Information}

Synthesis and NMR Elucidation of Novel Octa-Amino Acid Resorcin[4]arenes derivatives.

Iman Elidrisi, ${ }^{[a]}$ Pralav V. Bhatt, ${ }^{[\mathrm{b}]}$ Thavendran Govender, ${ }^{[\mathrm{b}]}$ Hendrik G. Kruger, ${ }^{[\mathrm{b}]}$ and Glenn E. M. Maguire, ${ }^{[\mathrm{a}]} *$

${ }^{a}$ School of Chemistry, University of KwaZulu--Natal, Westville Campus, Private Bag X54001, Durban 4000 South Africa,

${ }^{b}$ School of Pharmacology, University of KwaZulu--Natal, Westville Campus, Private Bag X54001, Durban 4000 South Africa

*Email: maguireg@ukzn.ac.za

Note that the NMR elucidation of the remainder of the compounds (i.e. those compounds that were not elucidated in the main paper) follows at the end of this document. The carbon 13 data are summarised in Table 1.

The following spectra are included:

S1: ${ }^{1}$ H NMR spectrum of 2,3 and $4 a-i$

S2: ${ }^{13} \mathrm{C}$ NMR spectrum of 2,3 and $4 a-i$

S3: COSY NMR spectrum of 4a-i

S4: HSQC NMR spectrum of 4a-i

S5: Infrared spectrum of 2,3 and $4 a-i$

Discussion about the NMR elucidation of the compounds not presented in the manuscript. 


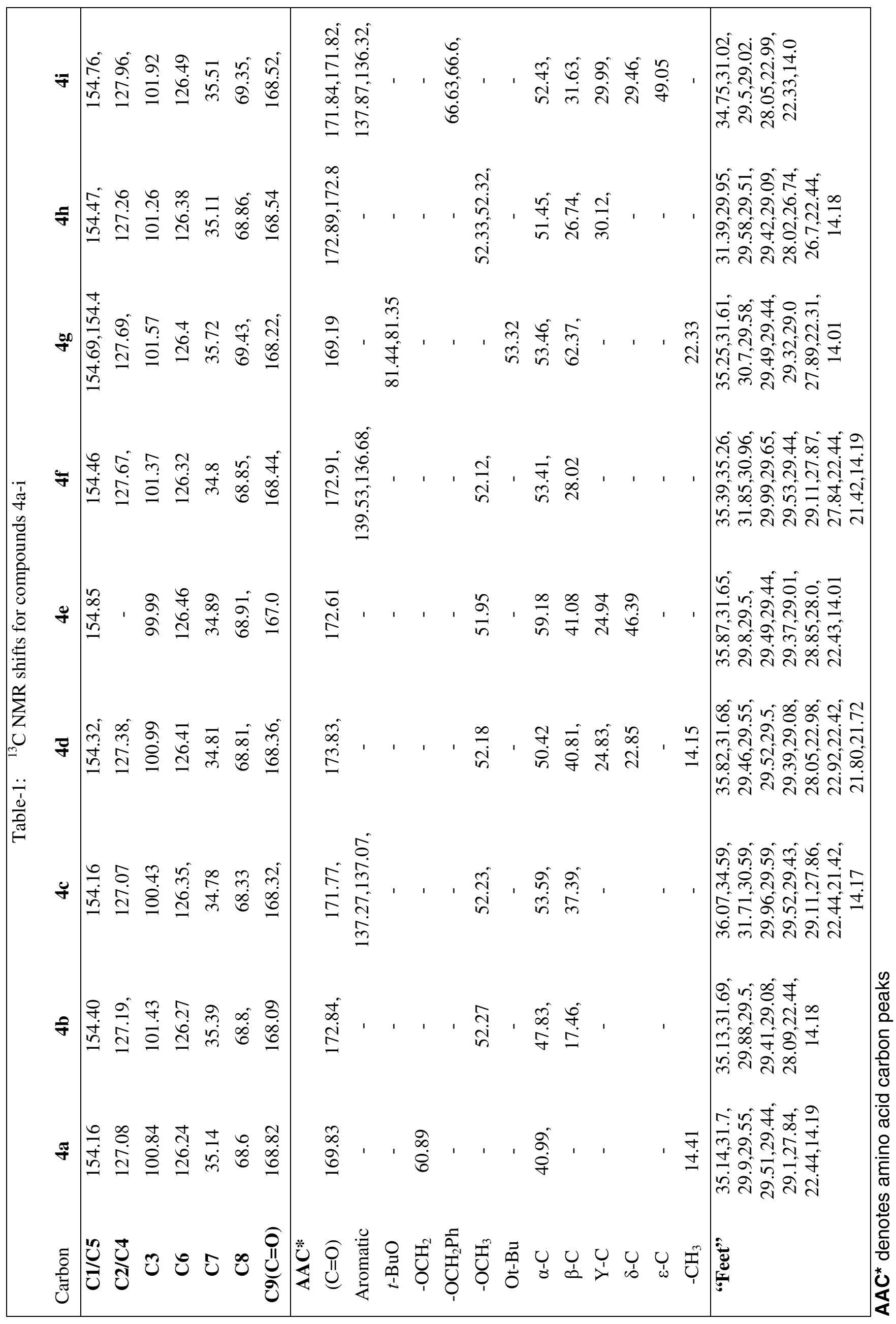




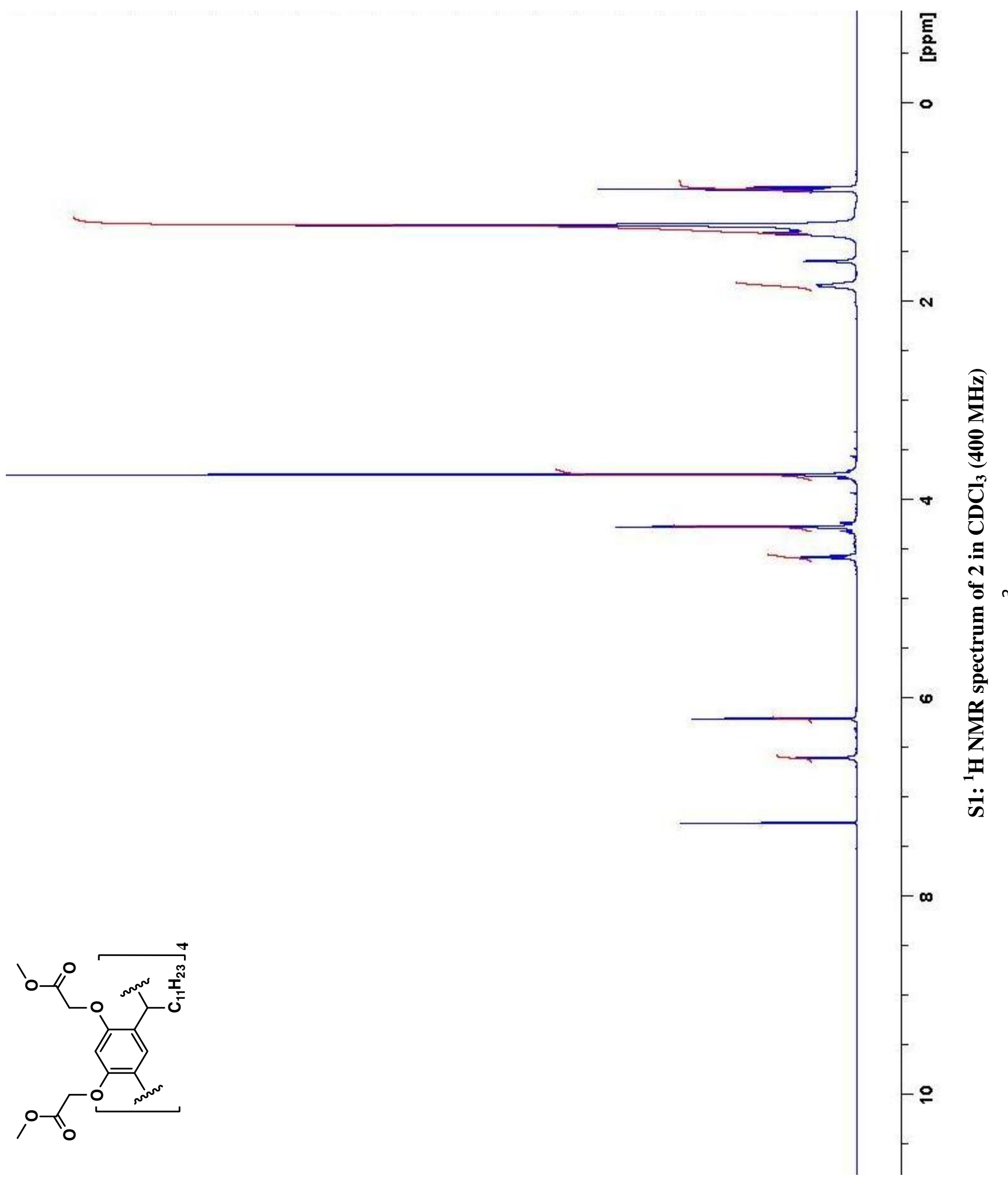




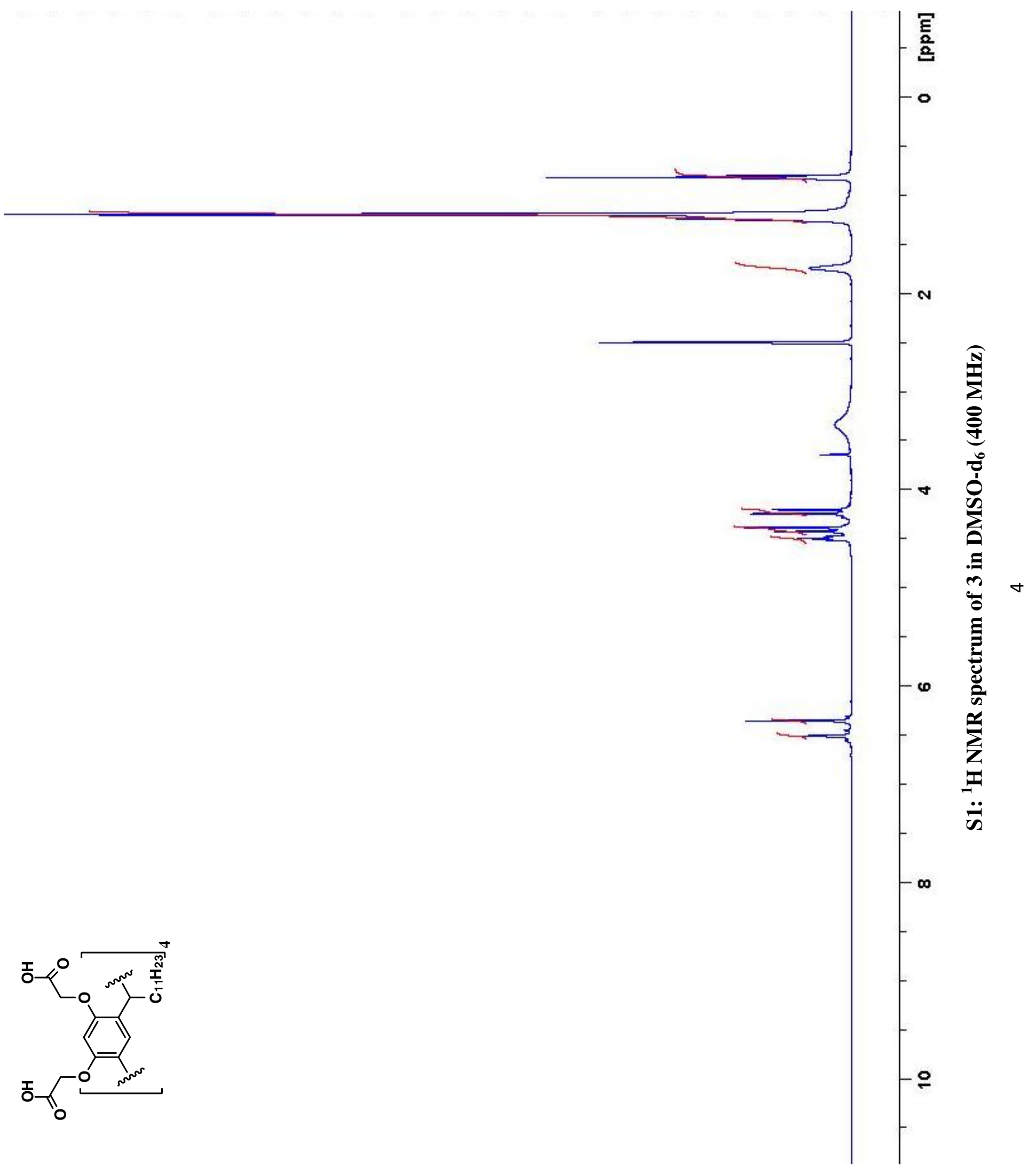




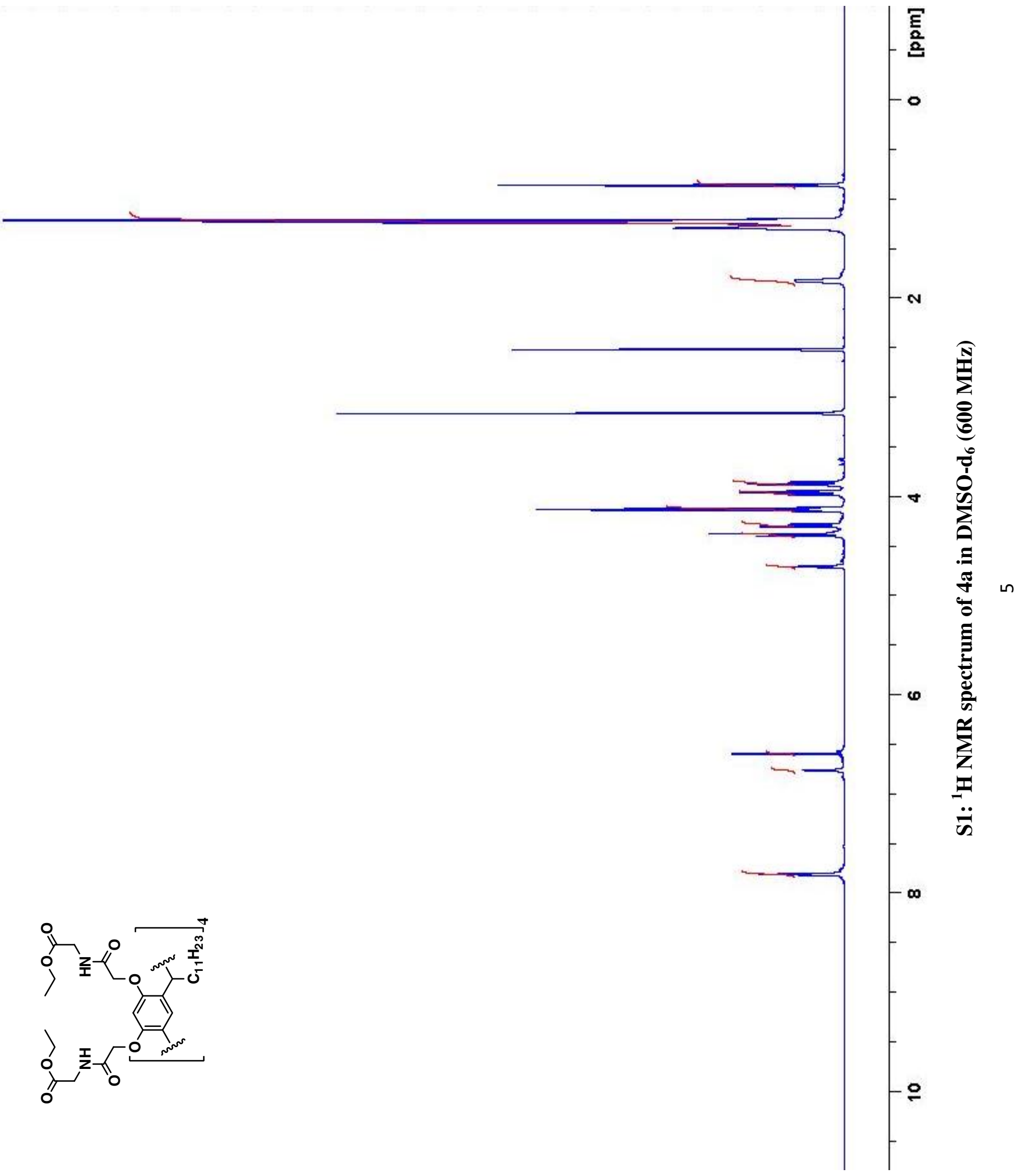




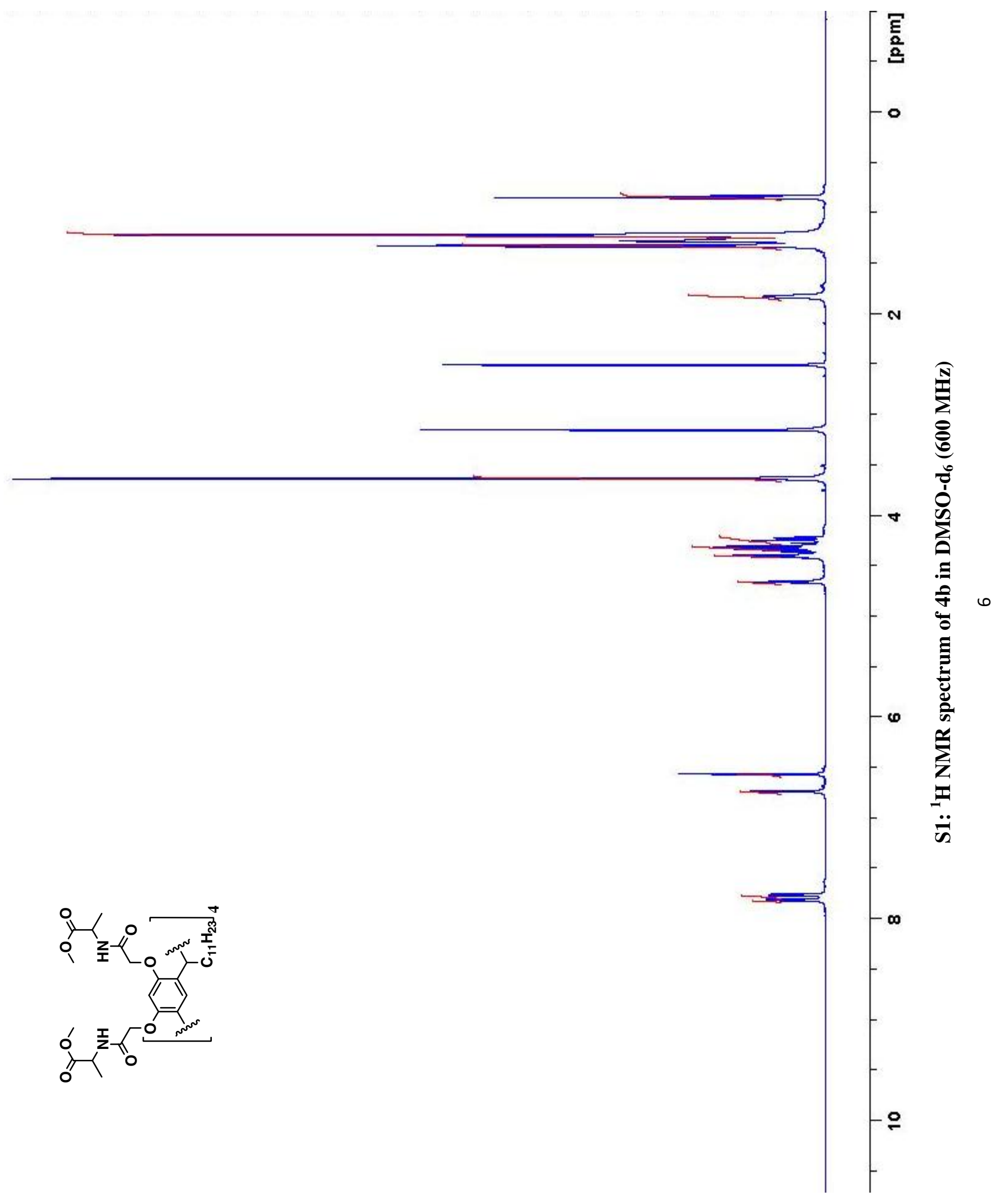




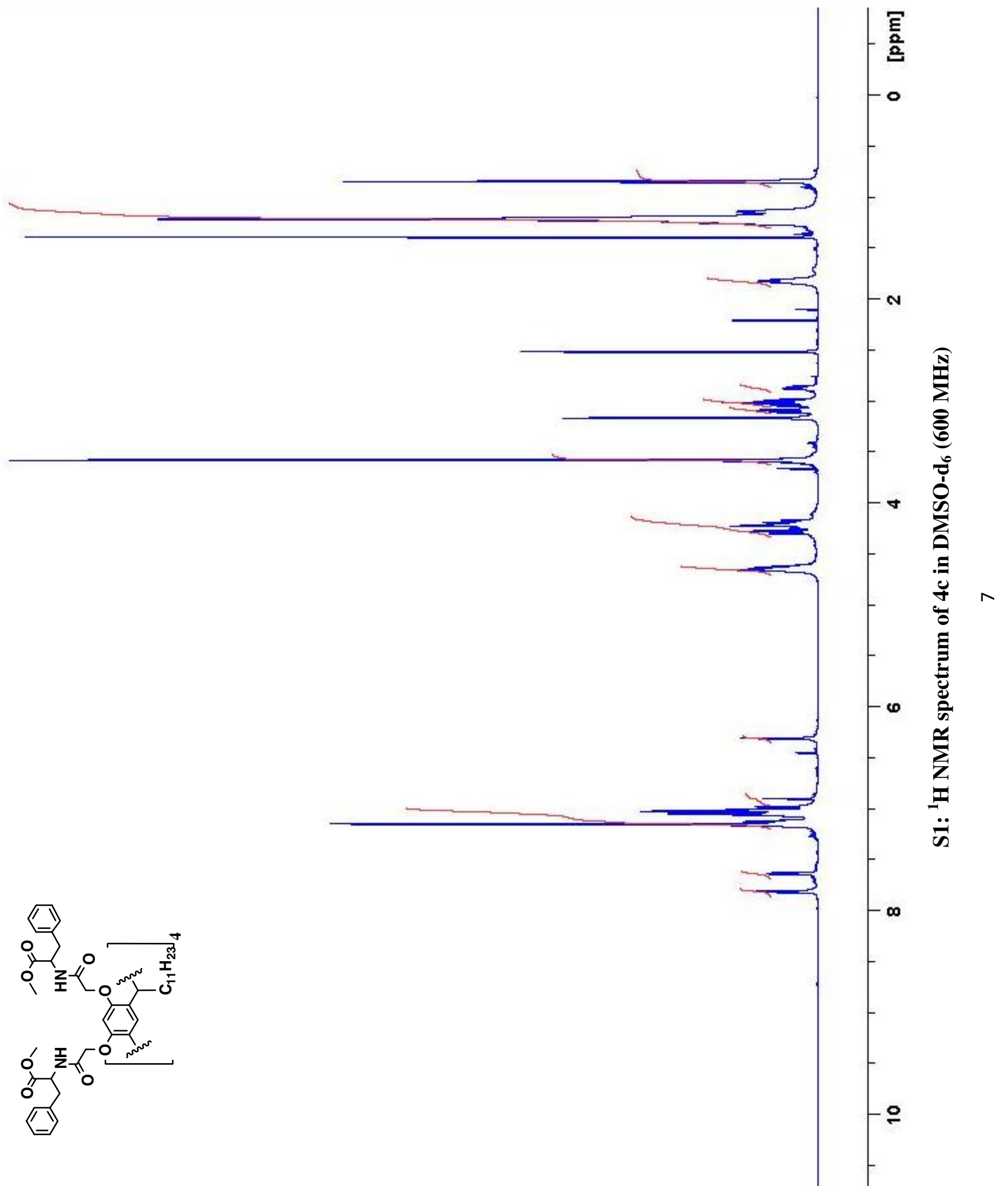




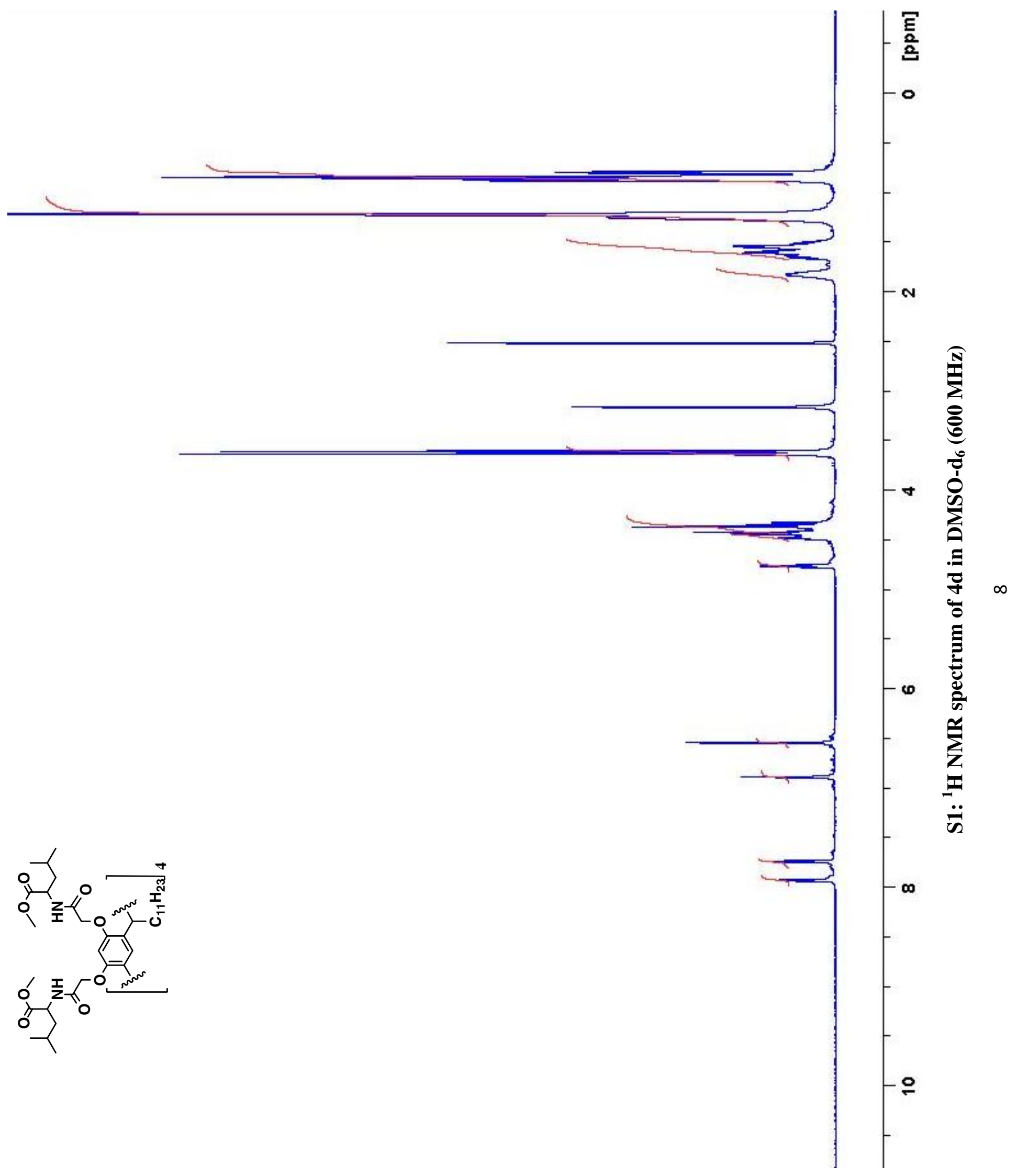




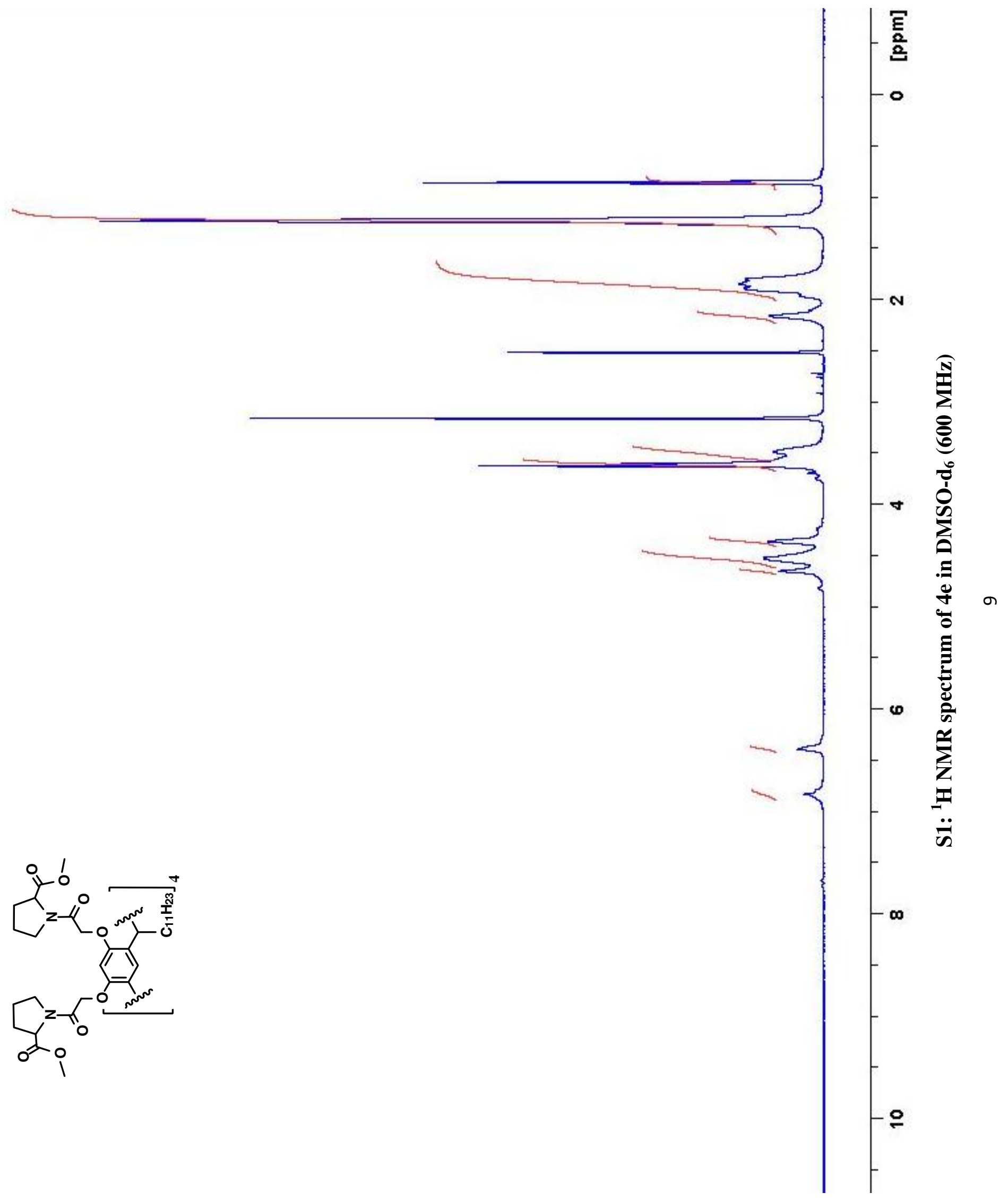




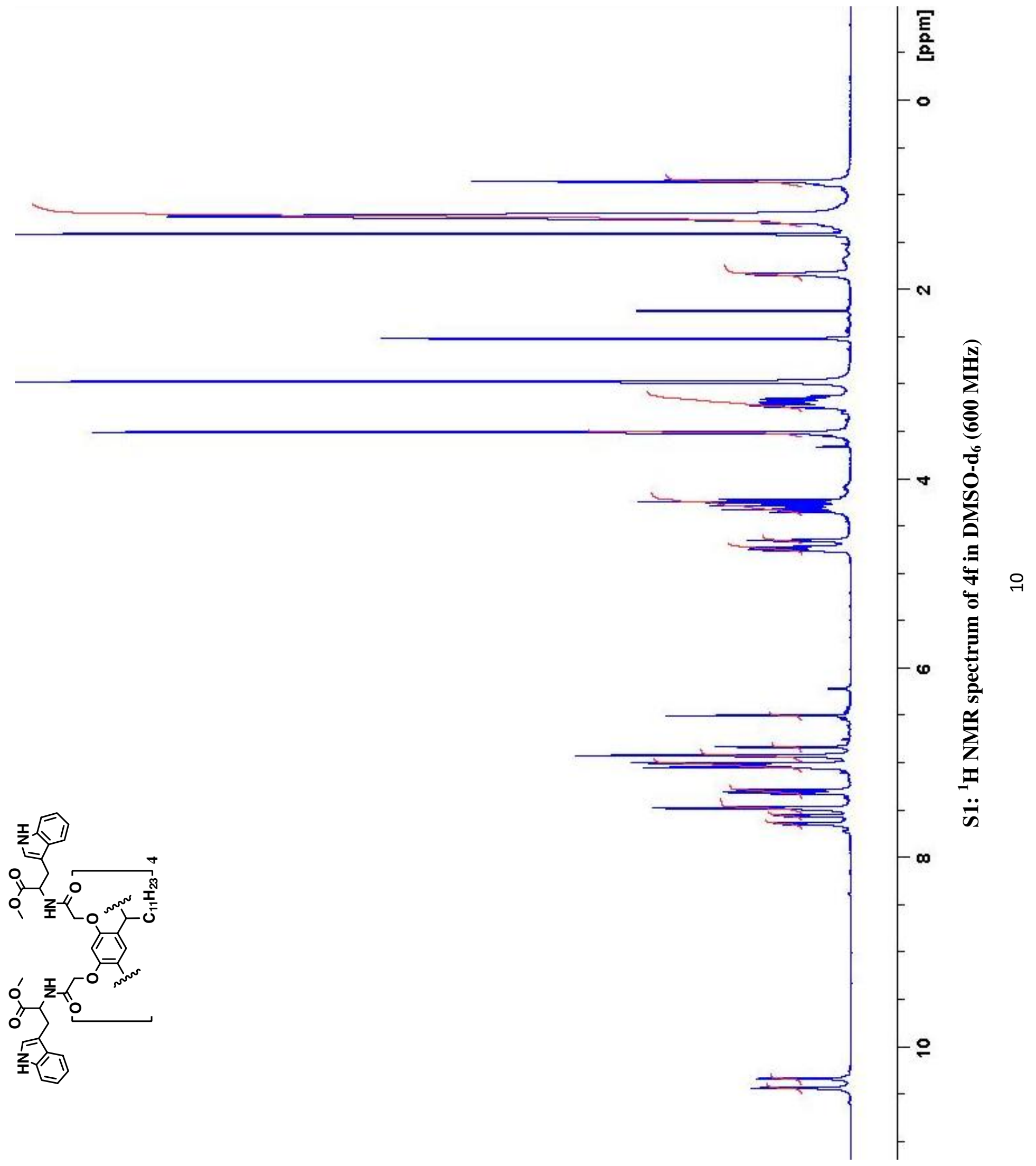




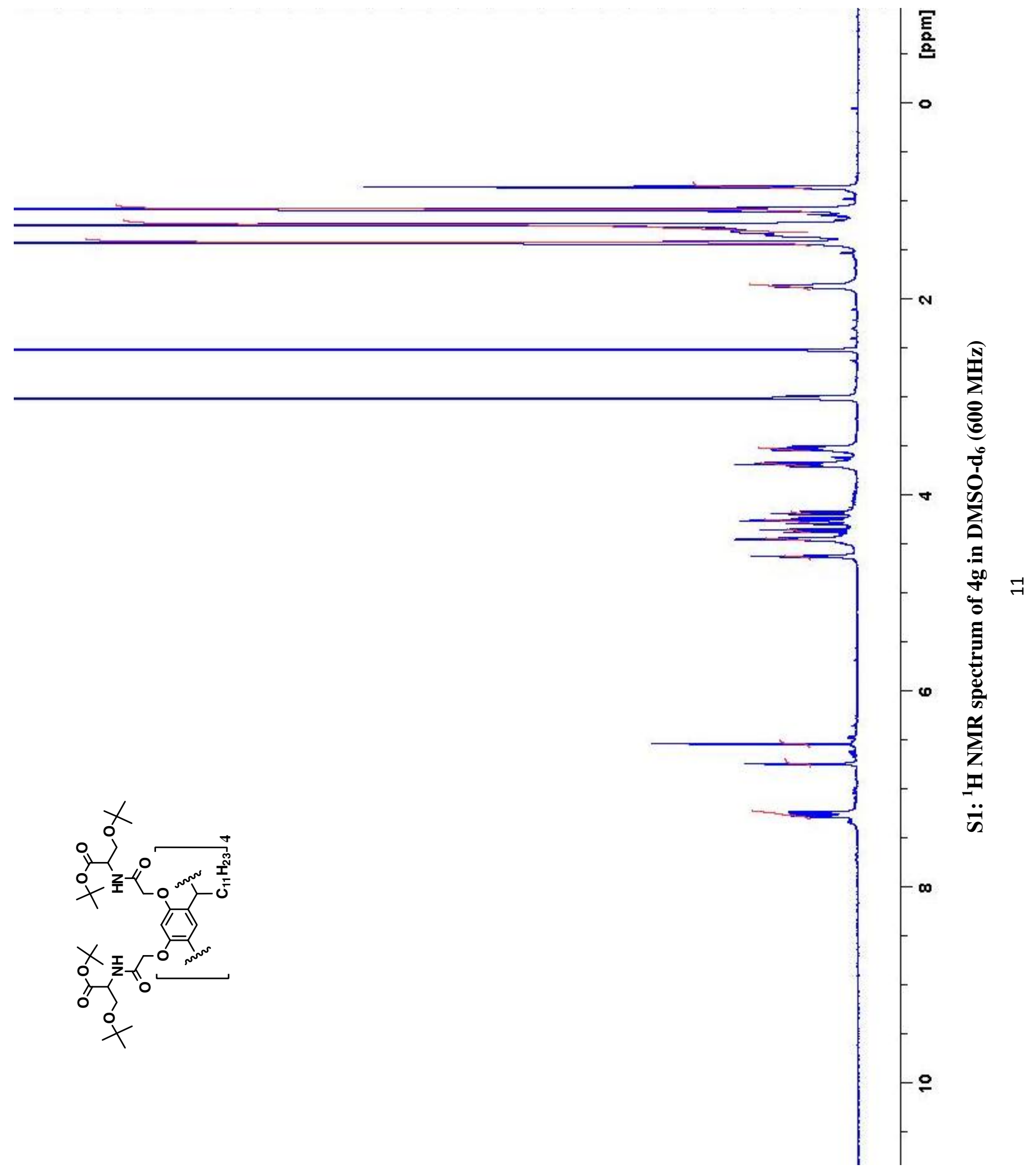




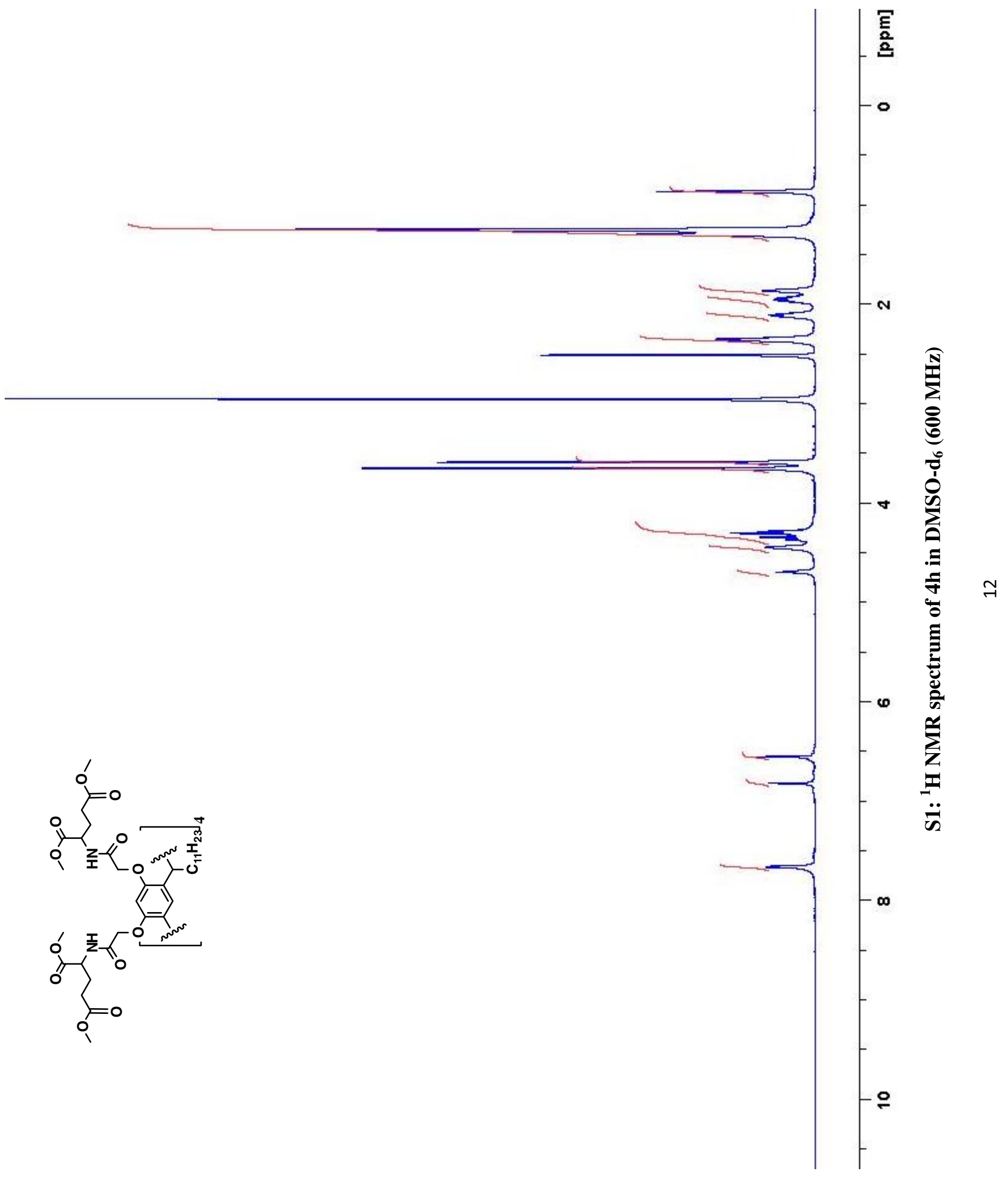




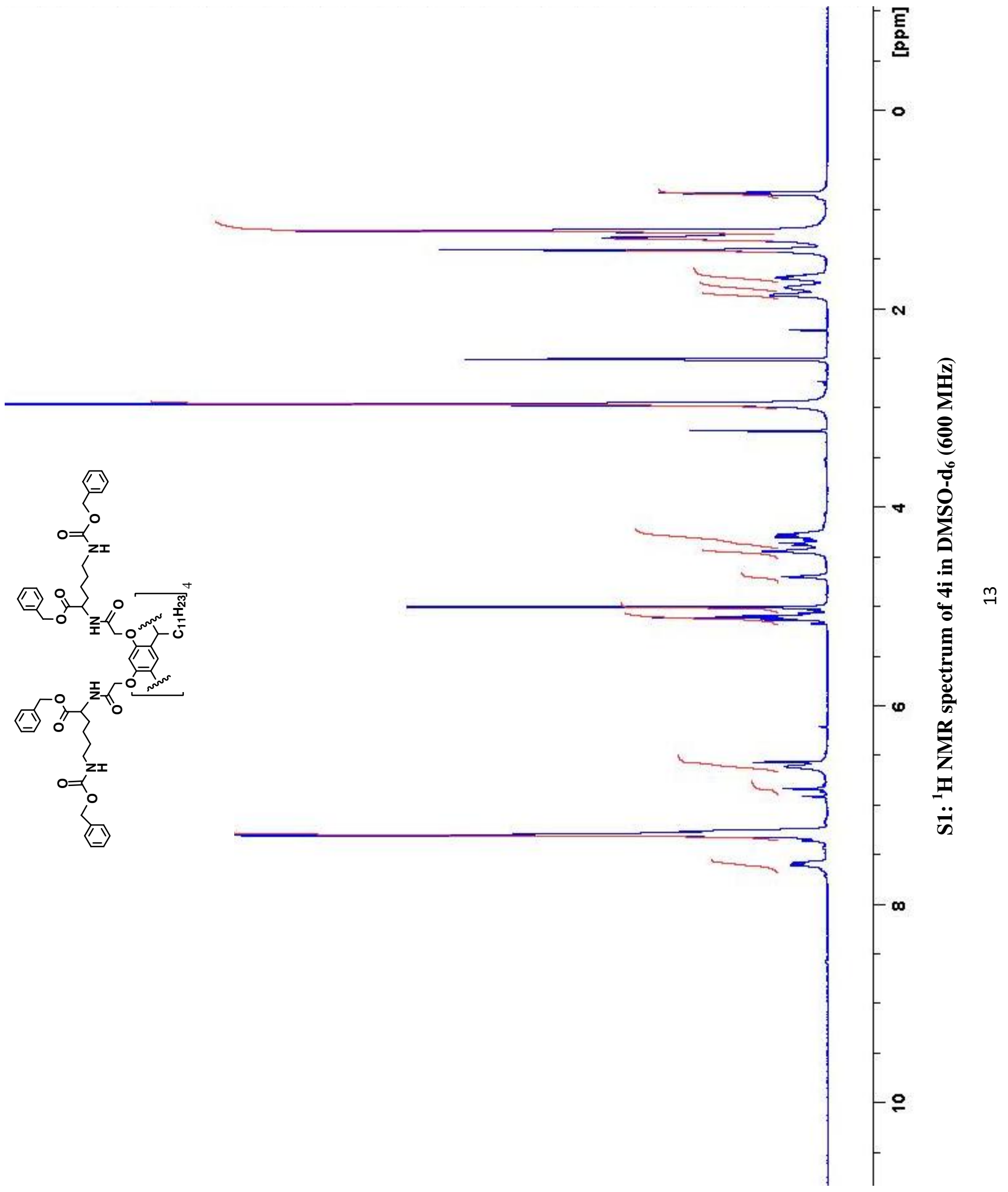




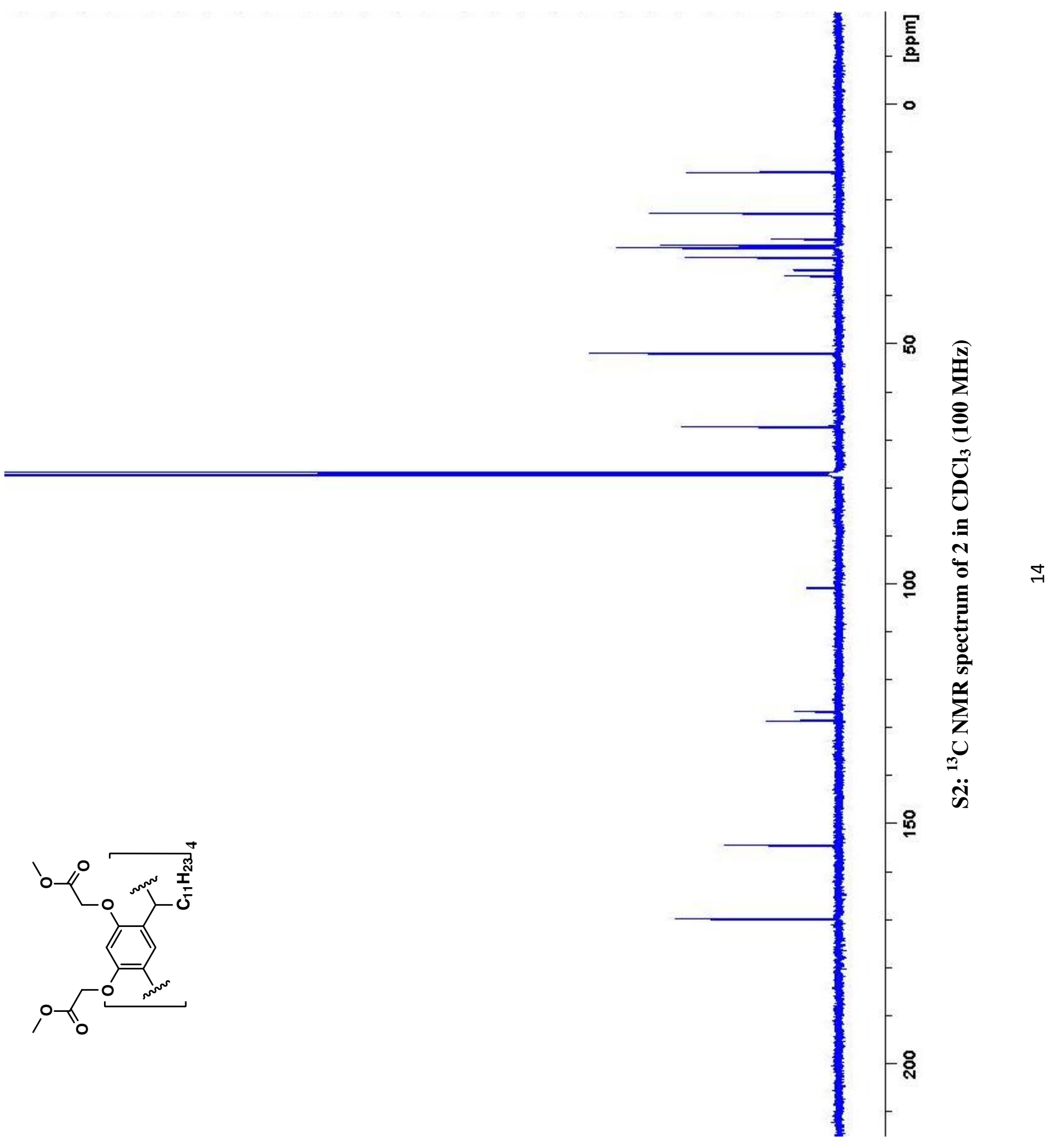




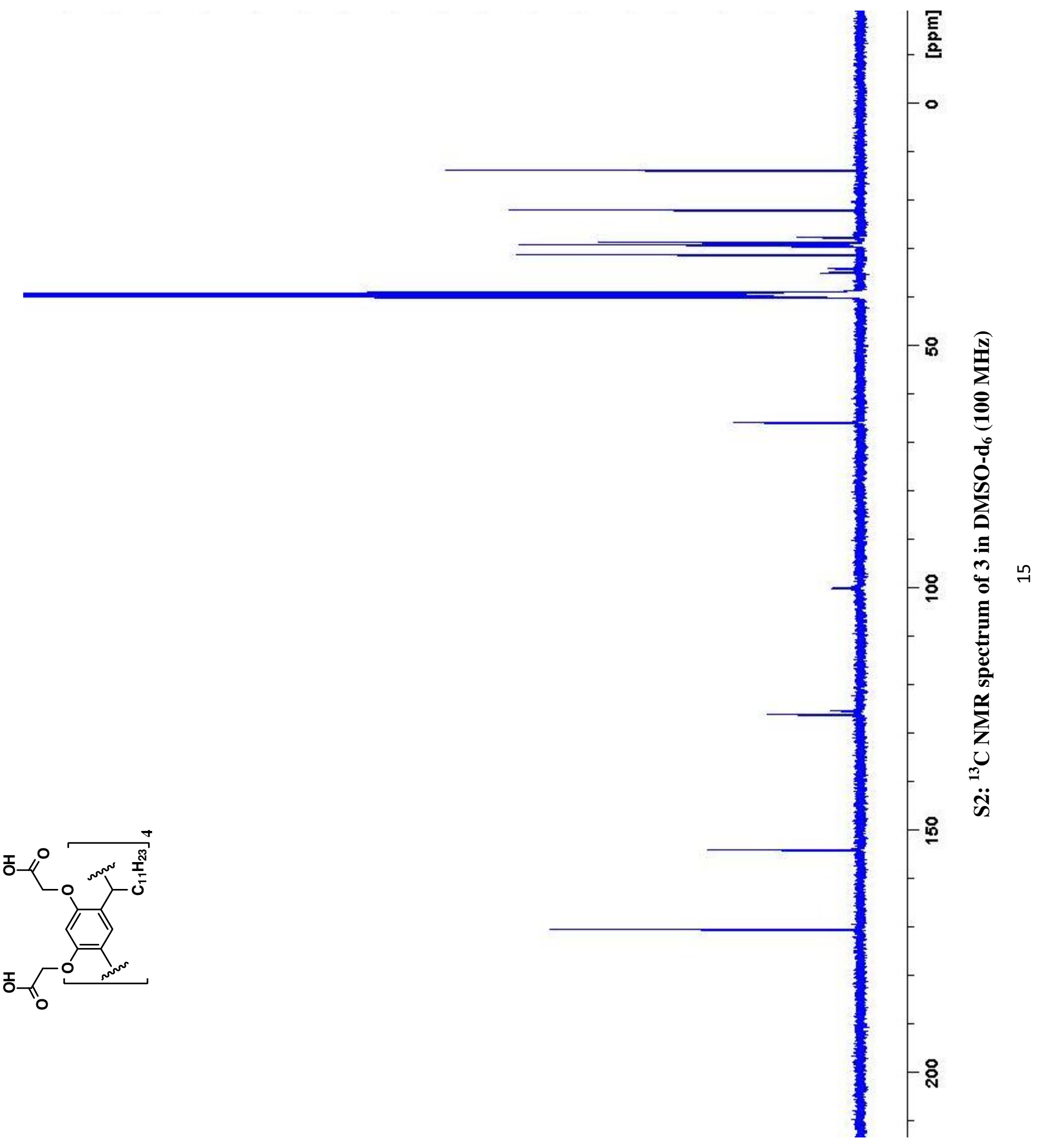




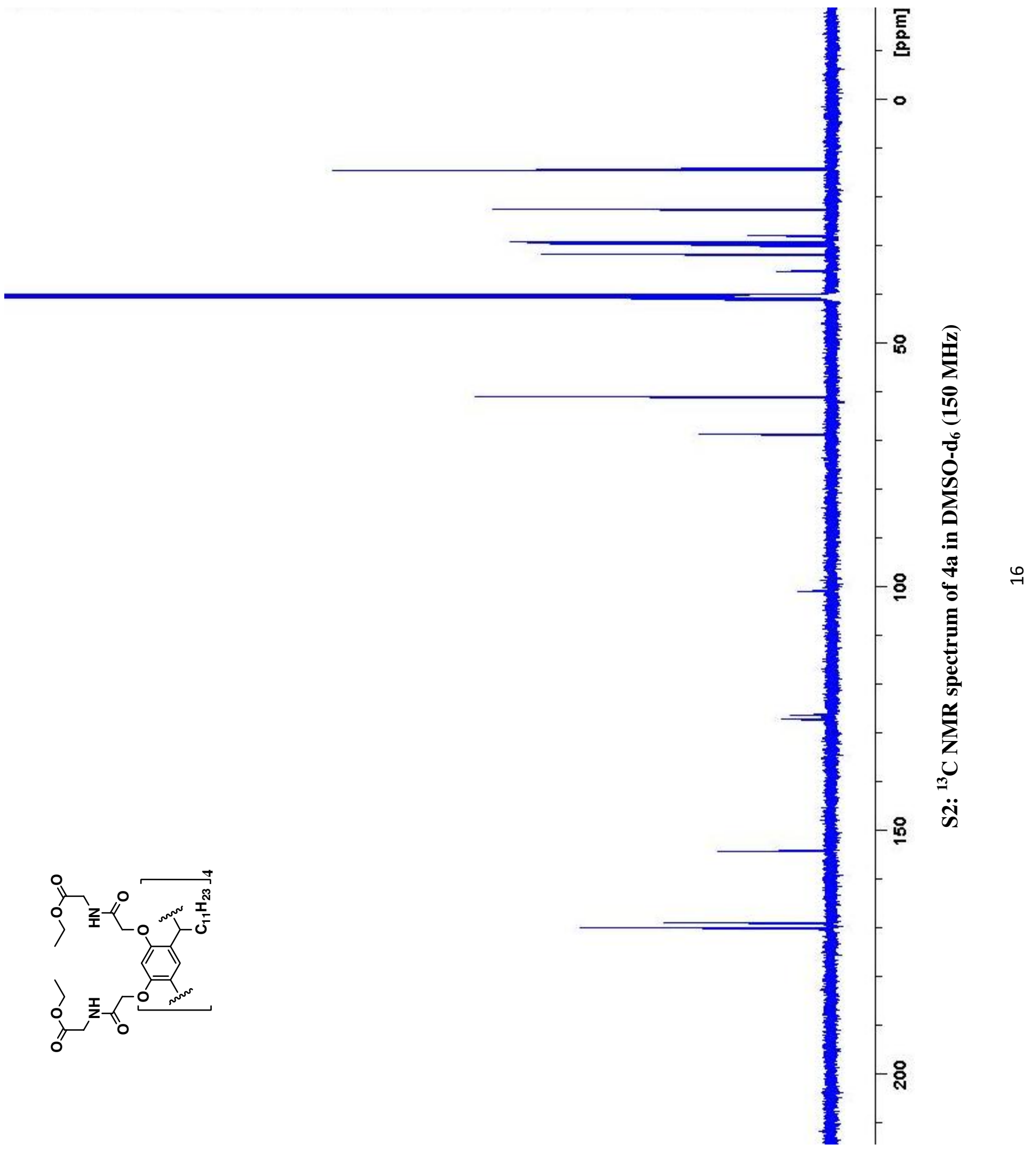




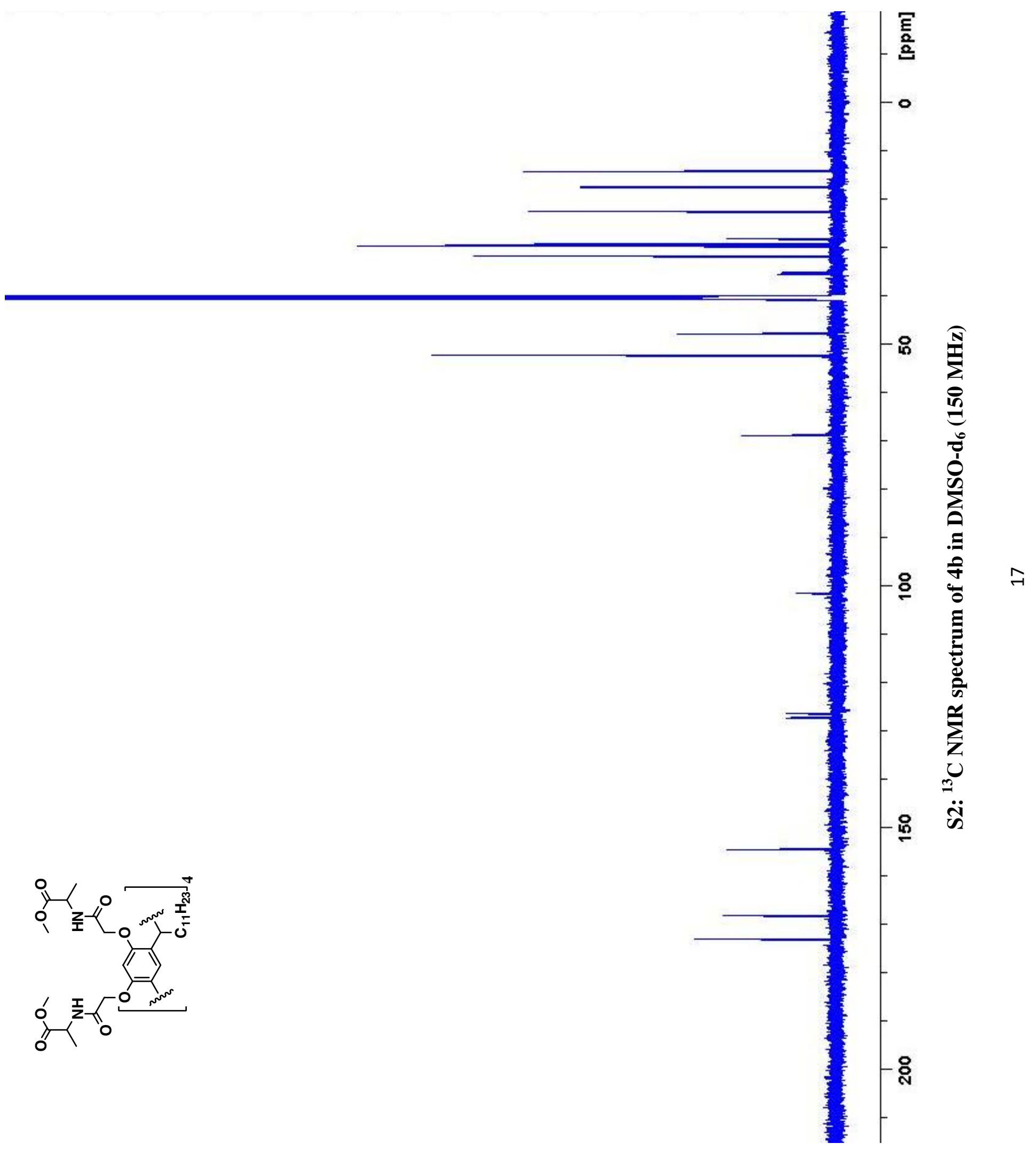




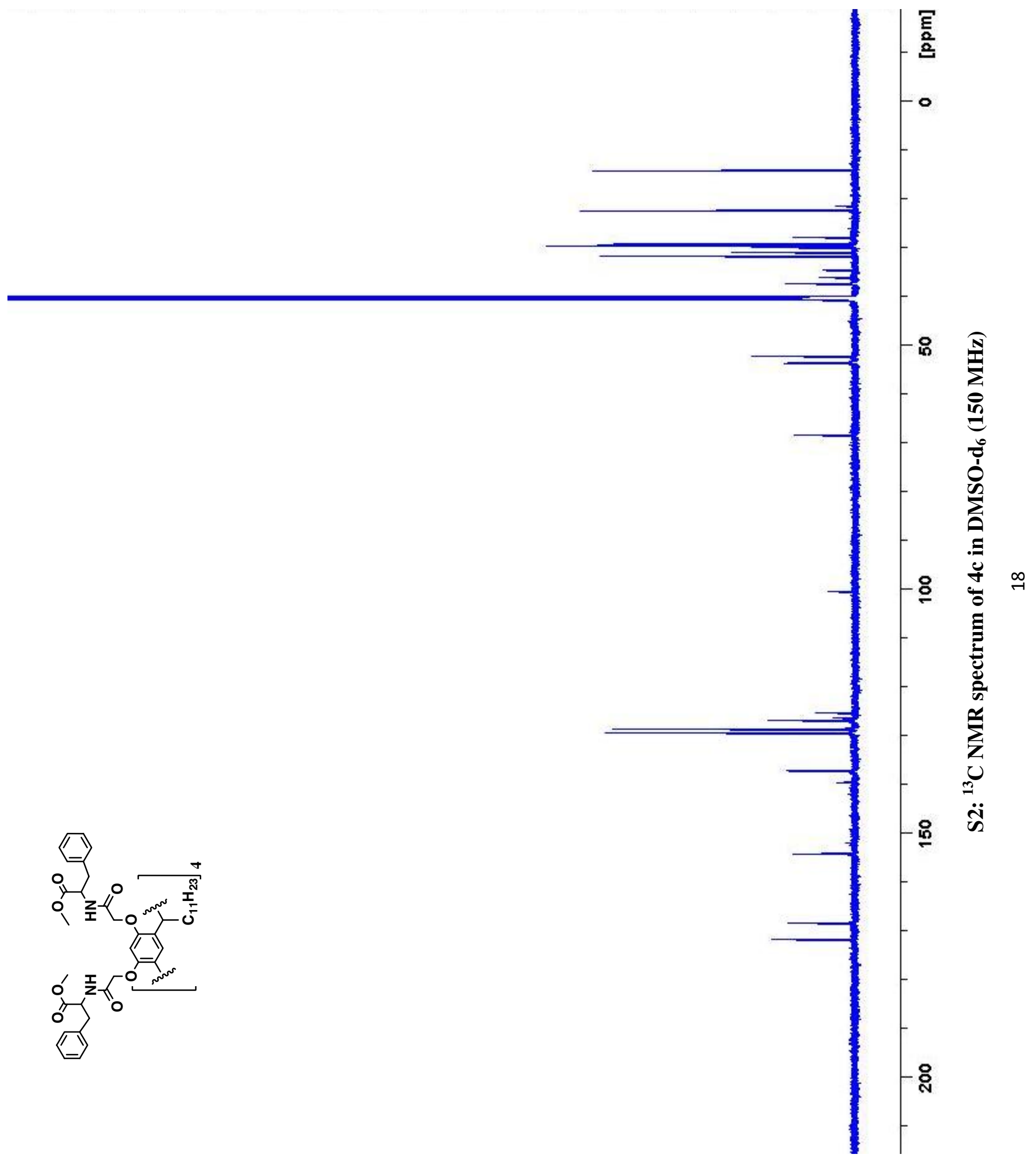




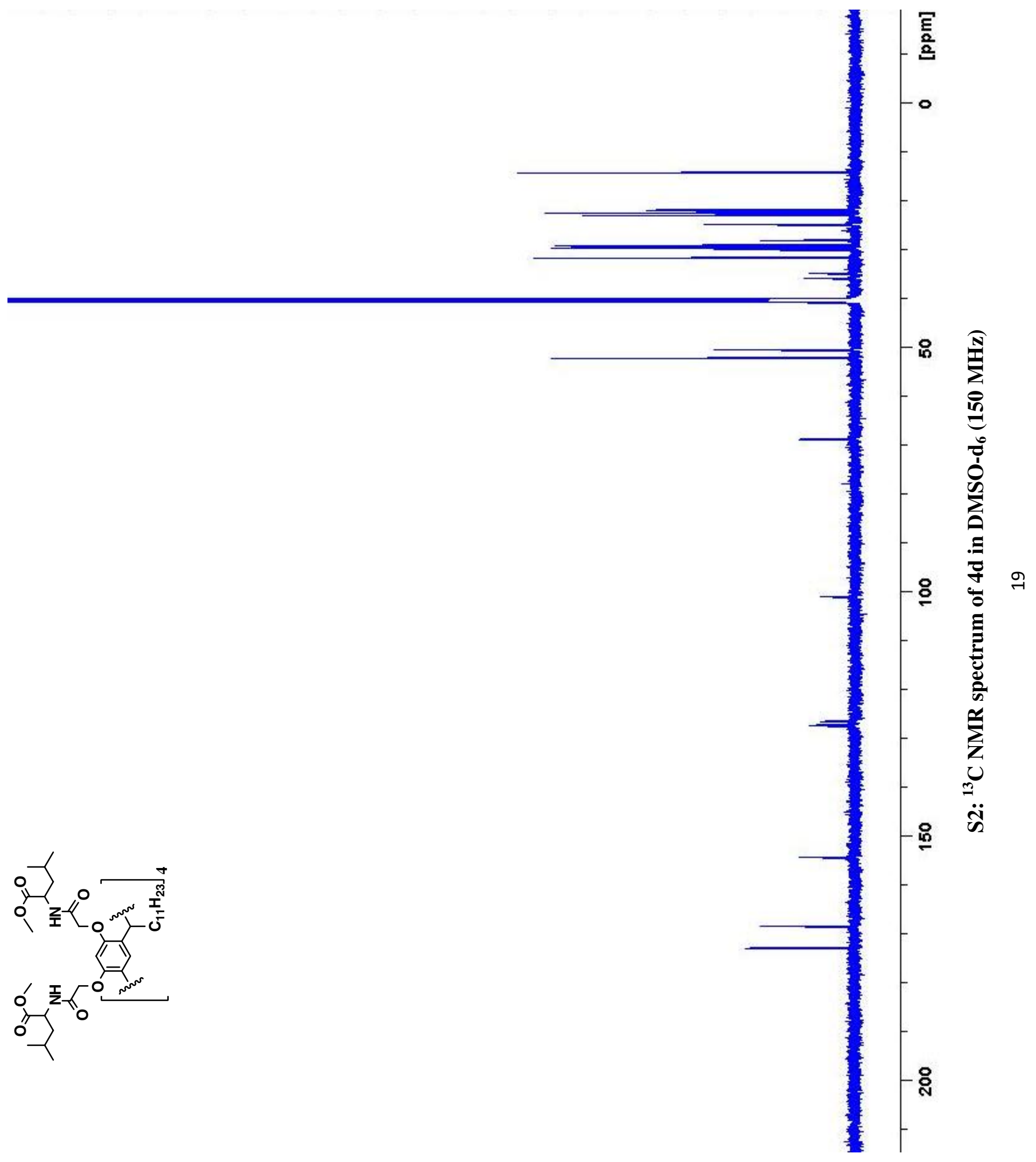




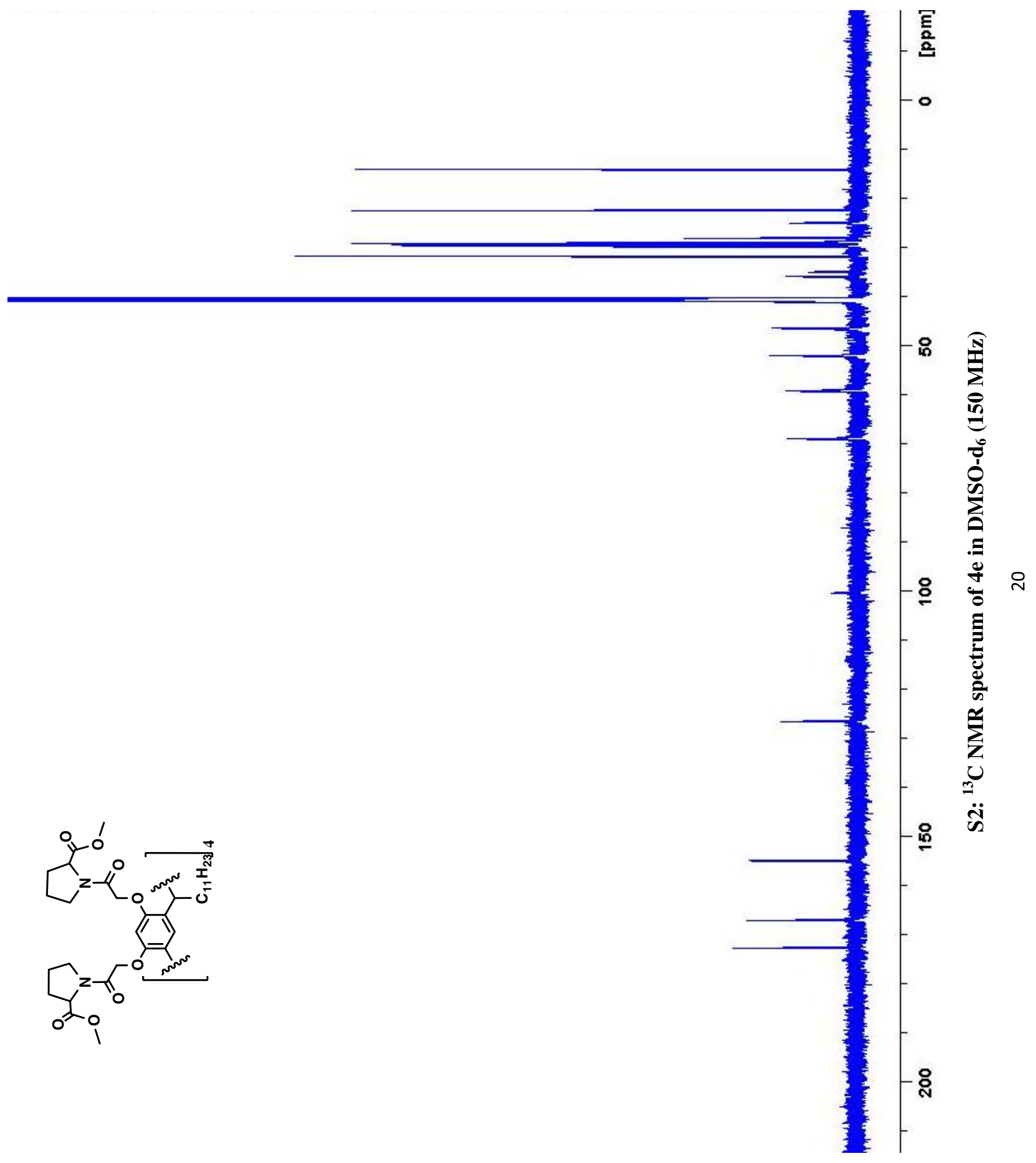




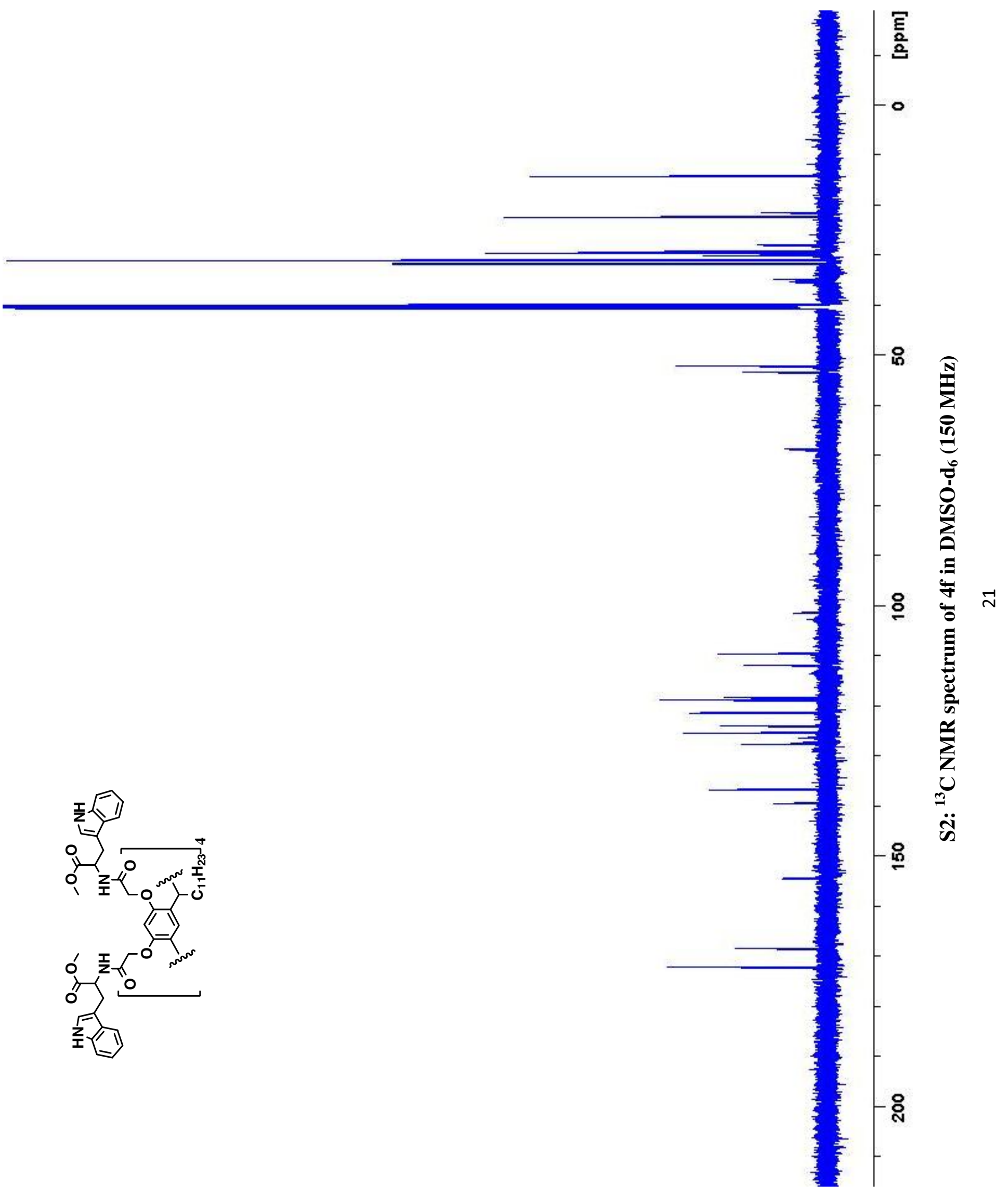




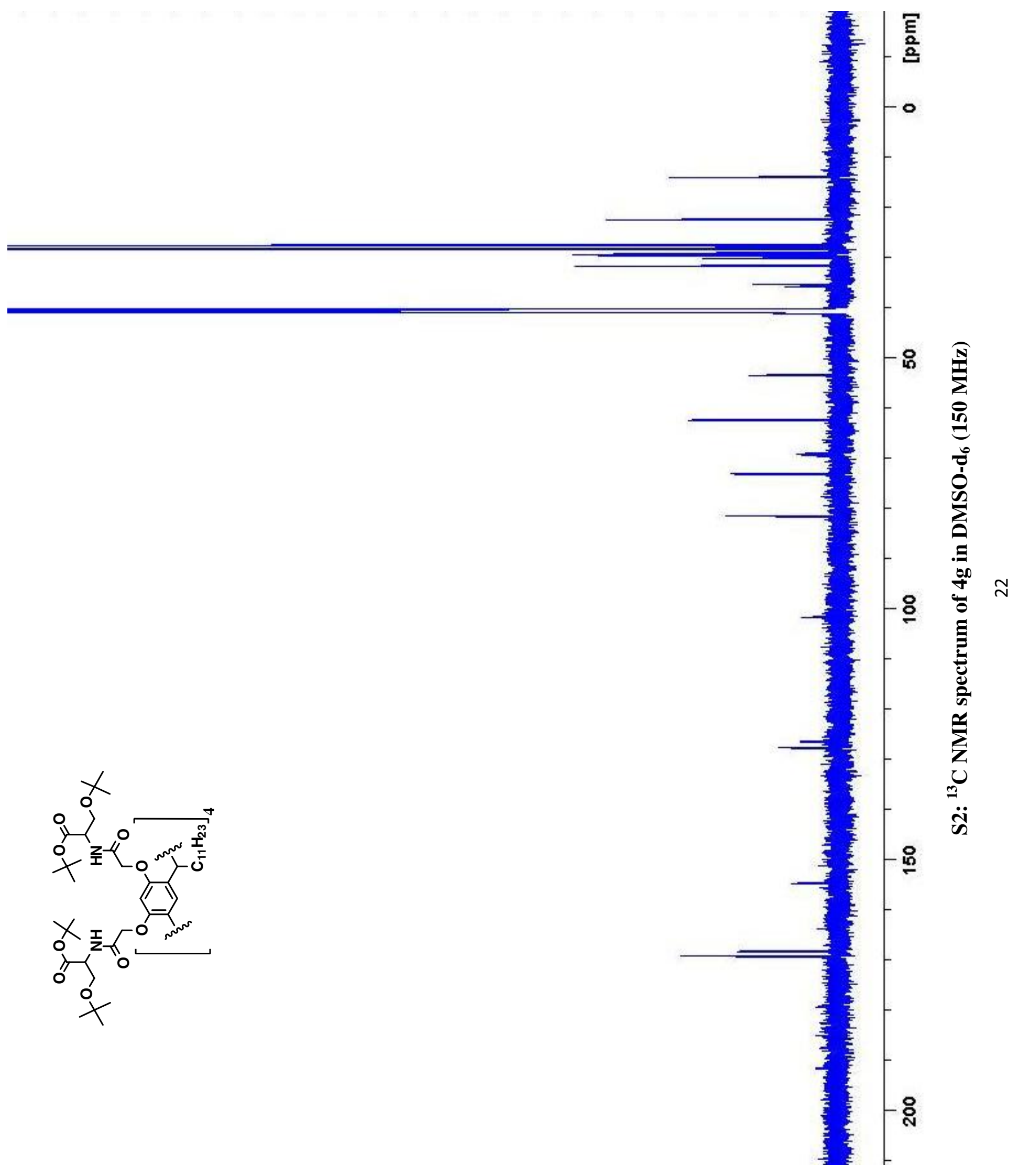




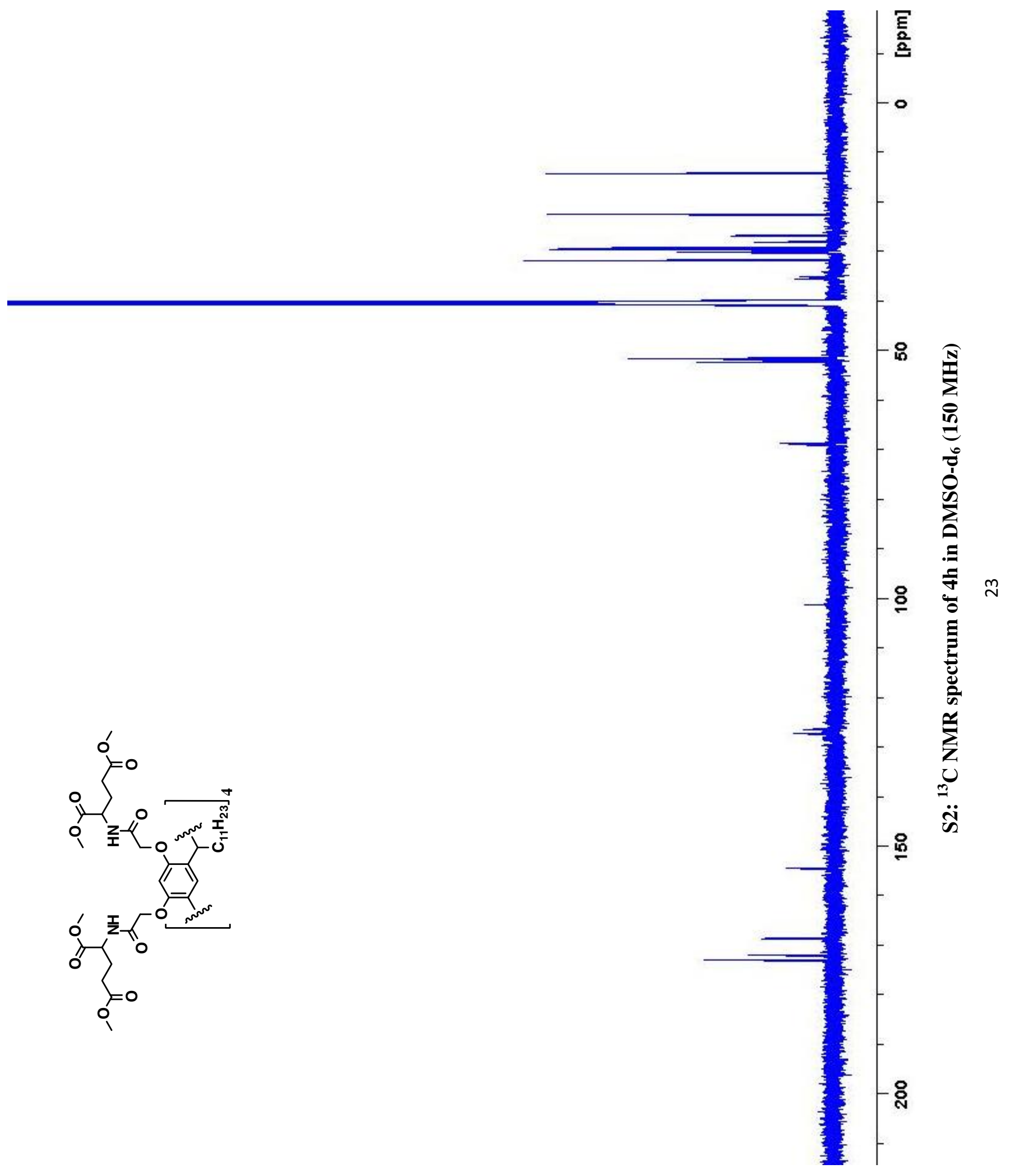




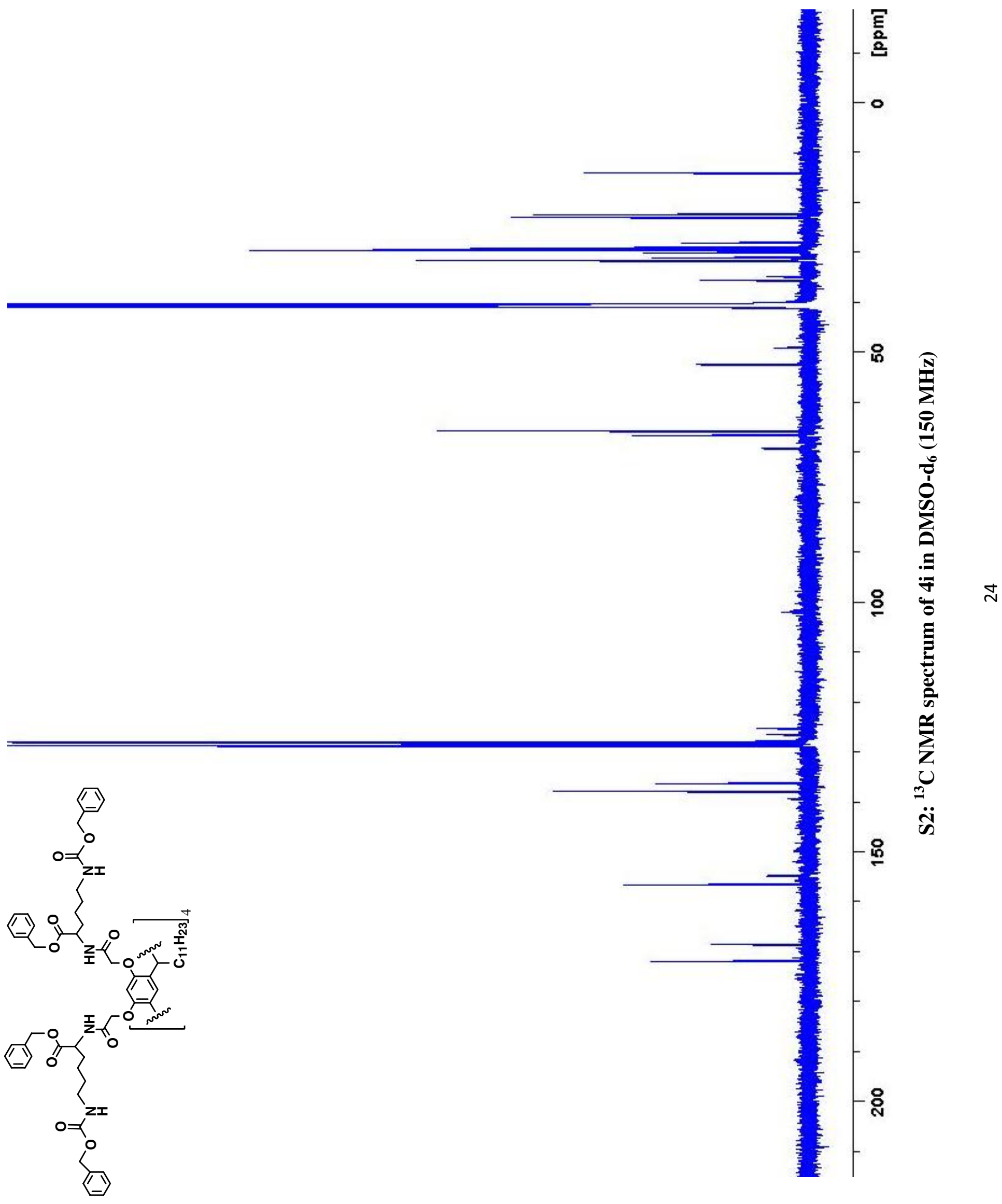




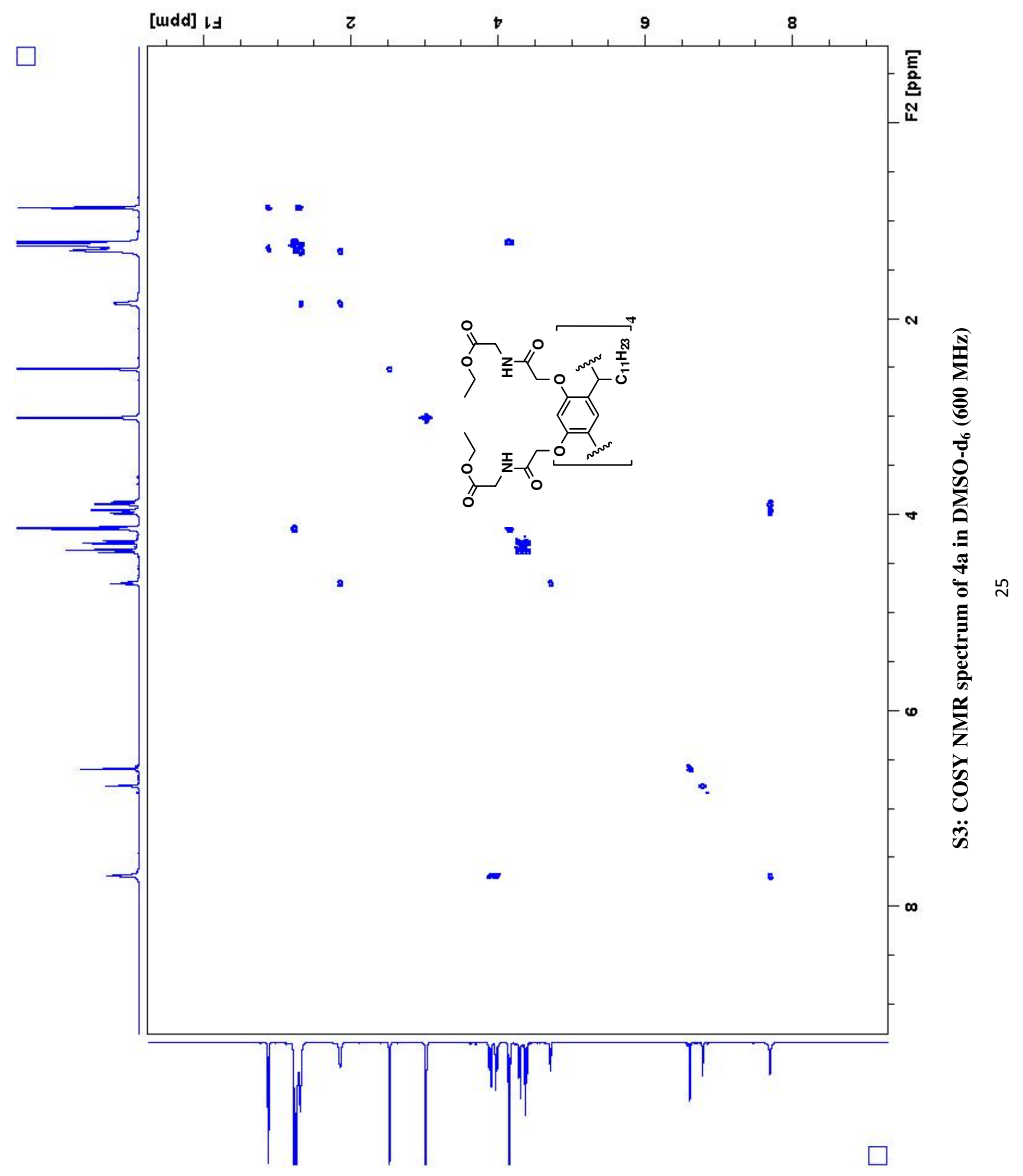




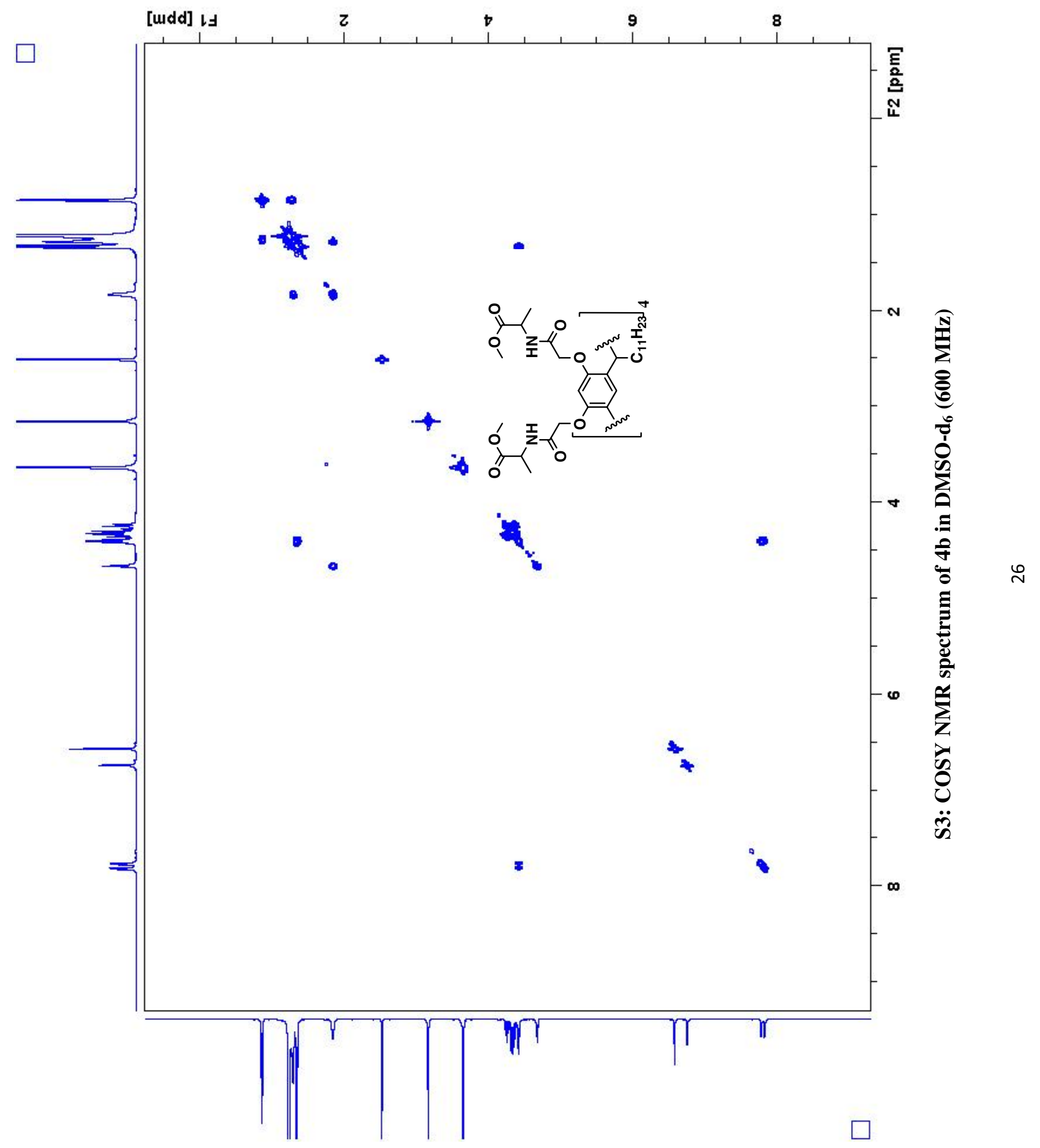




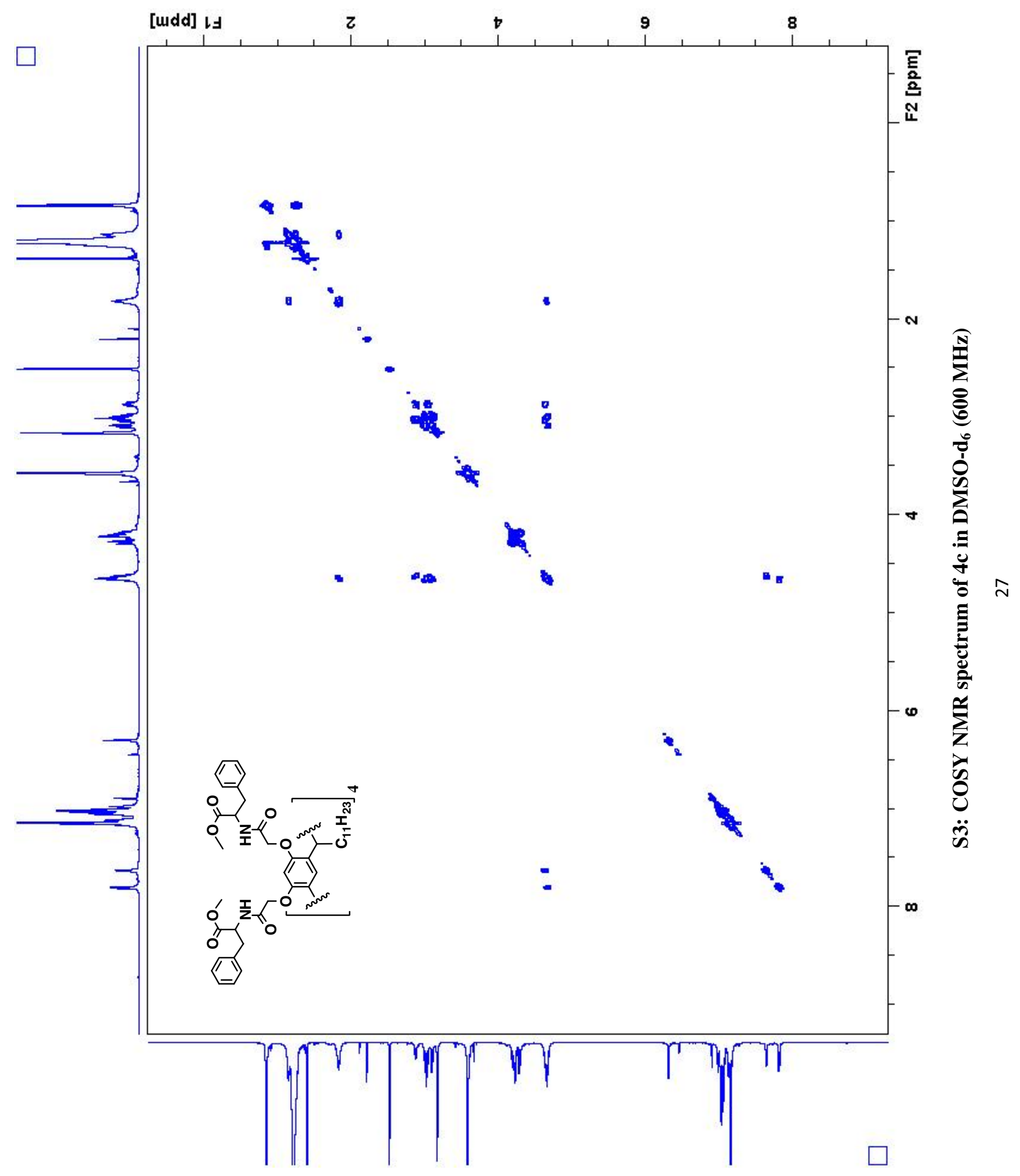




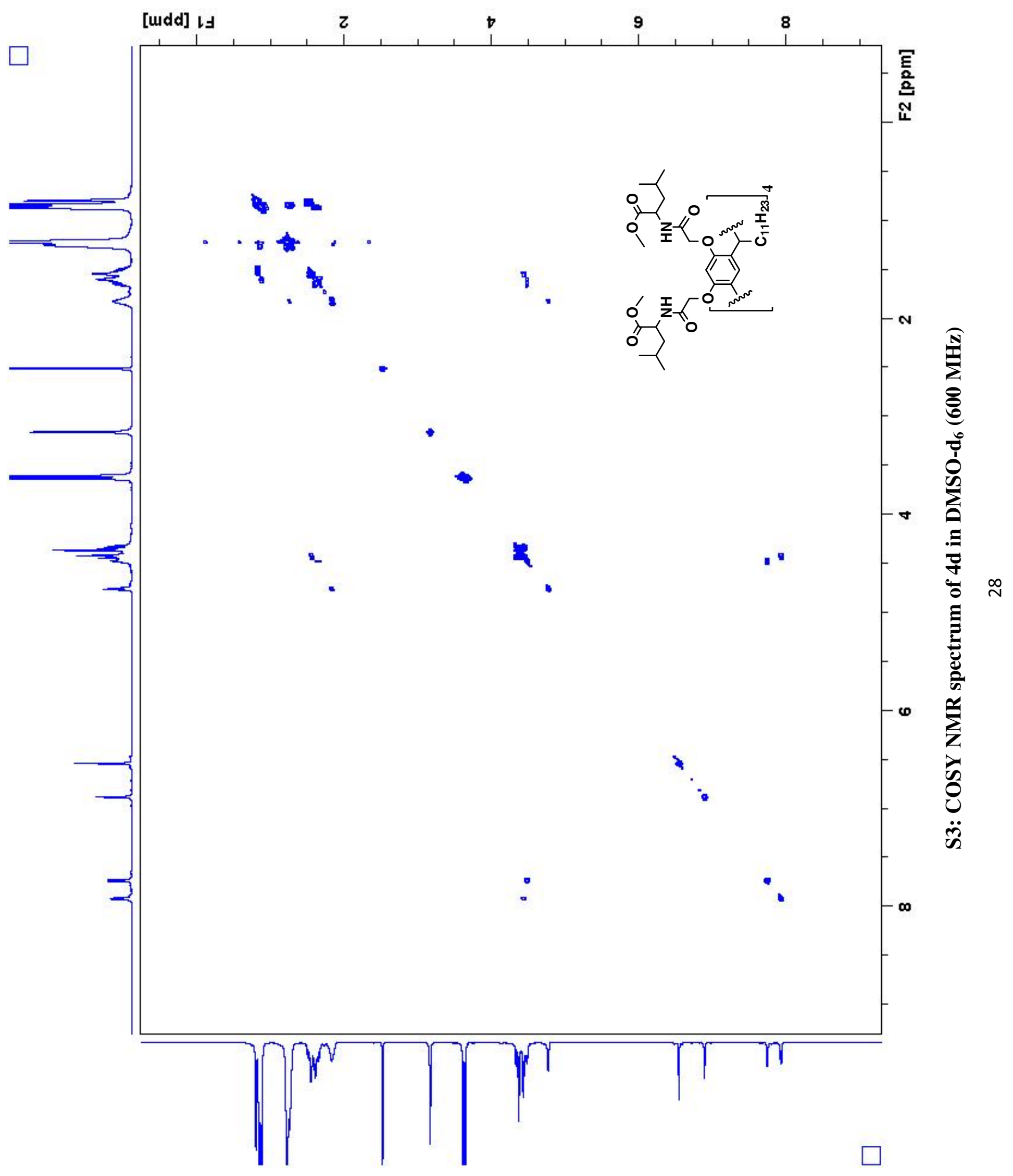




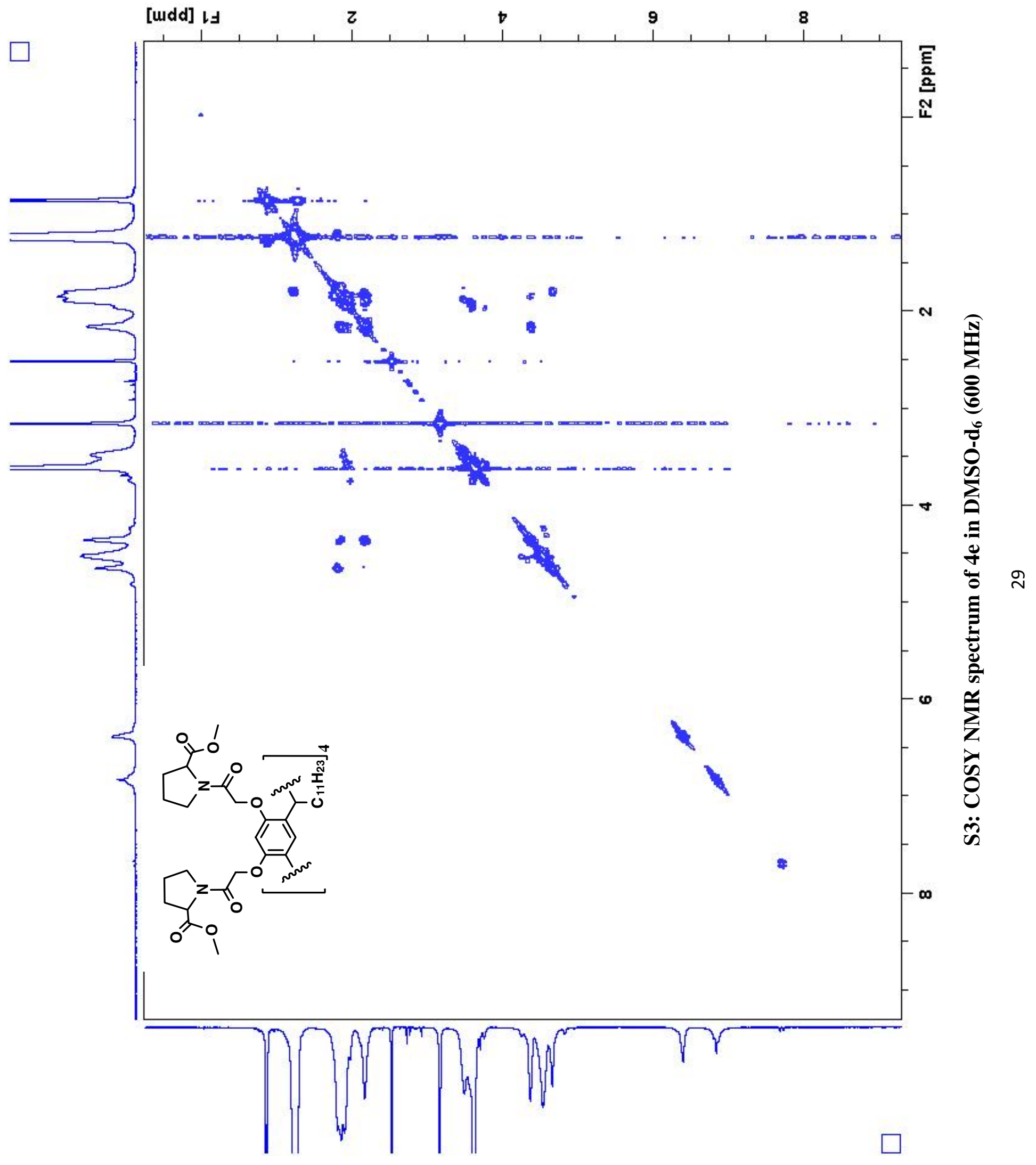




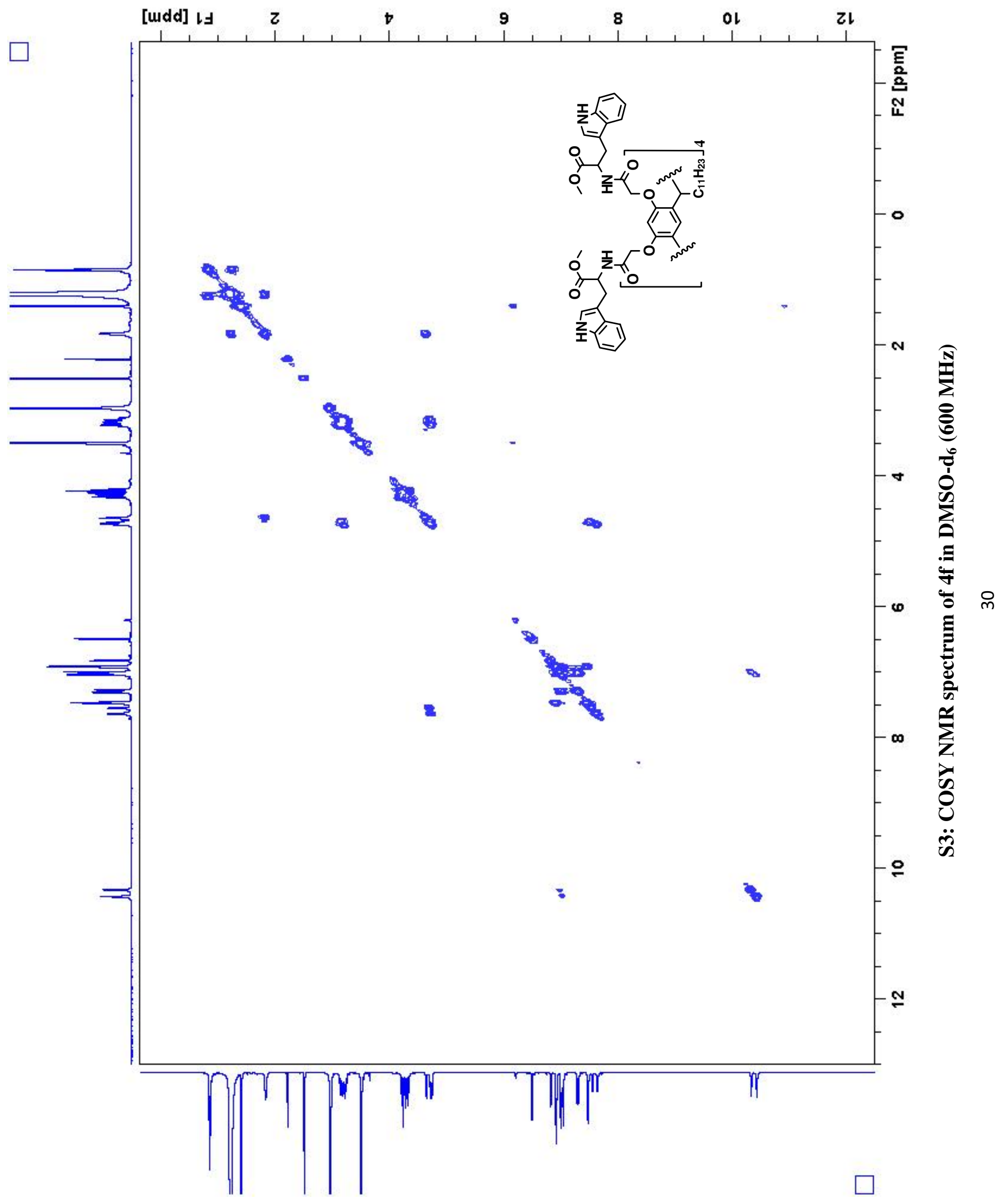




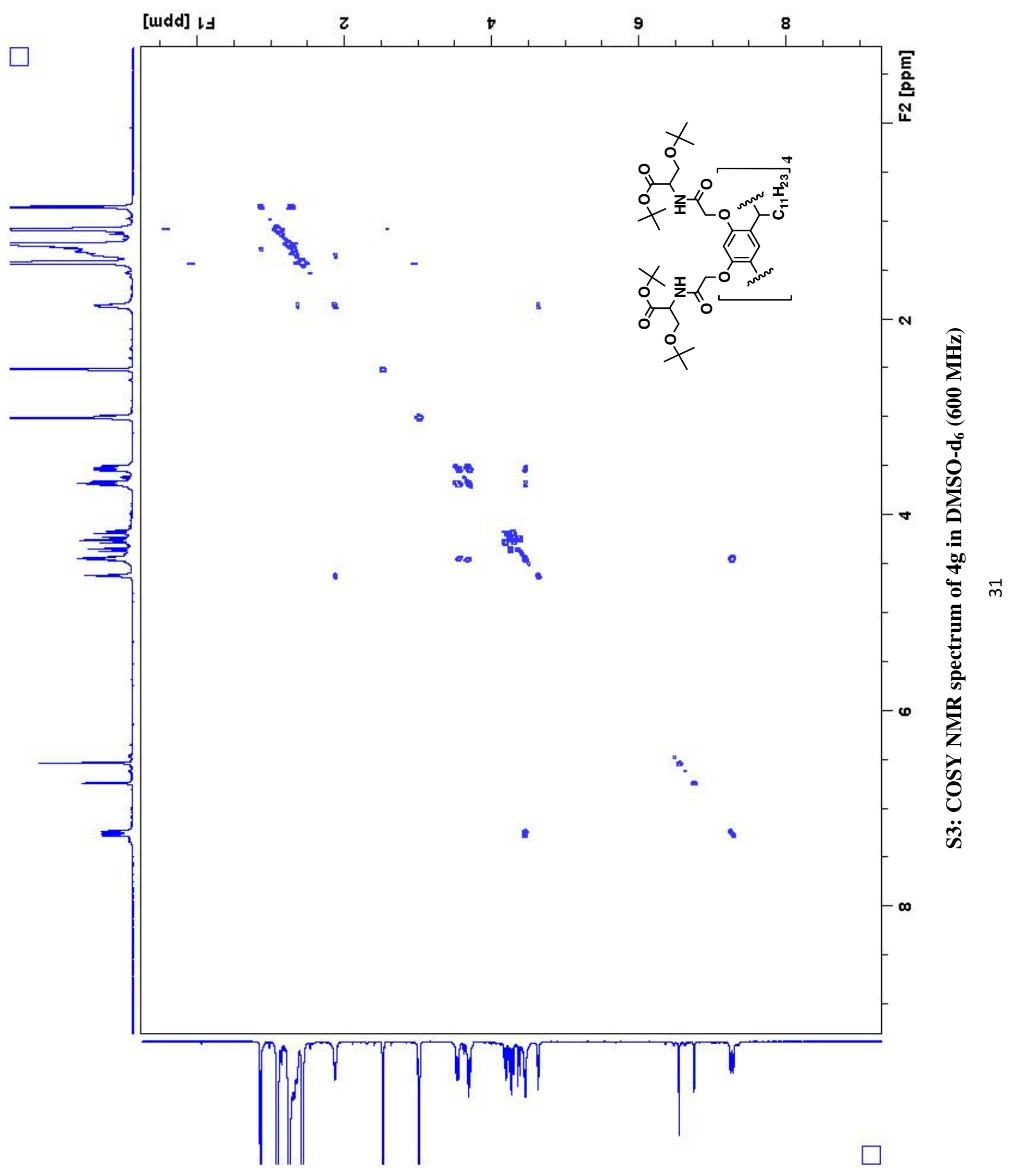




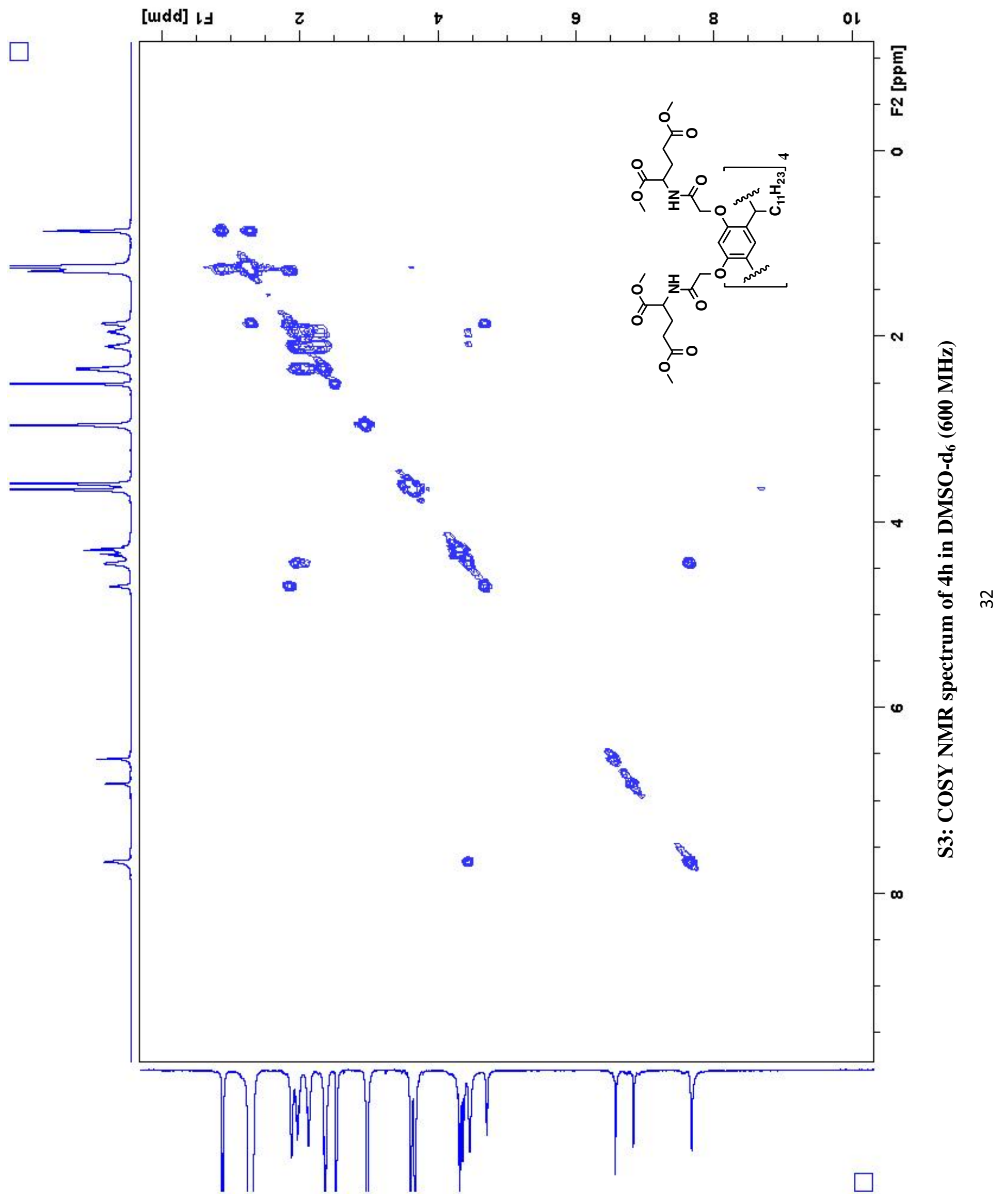




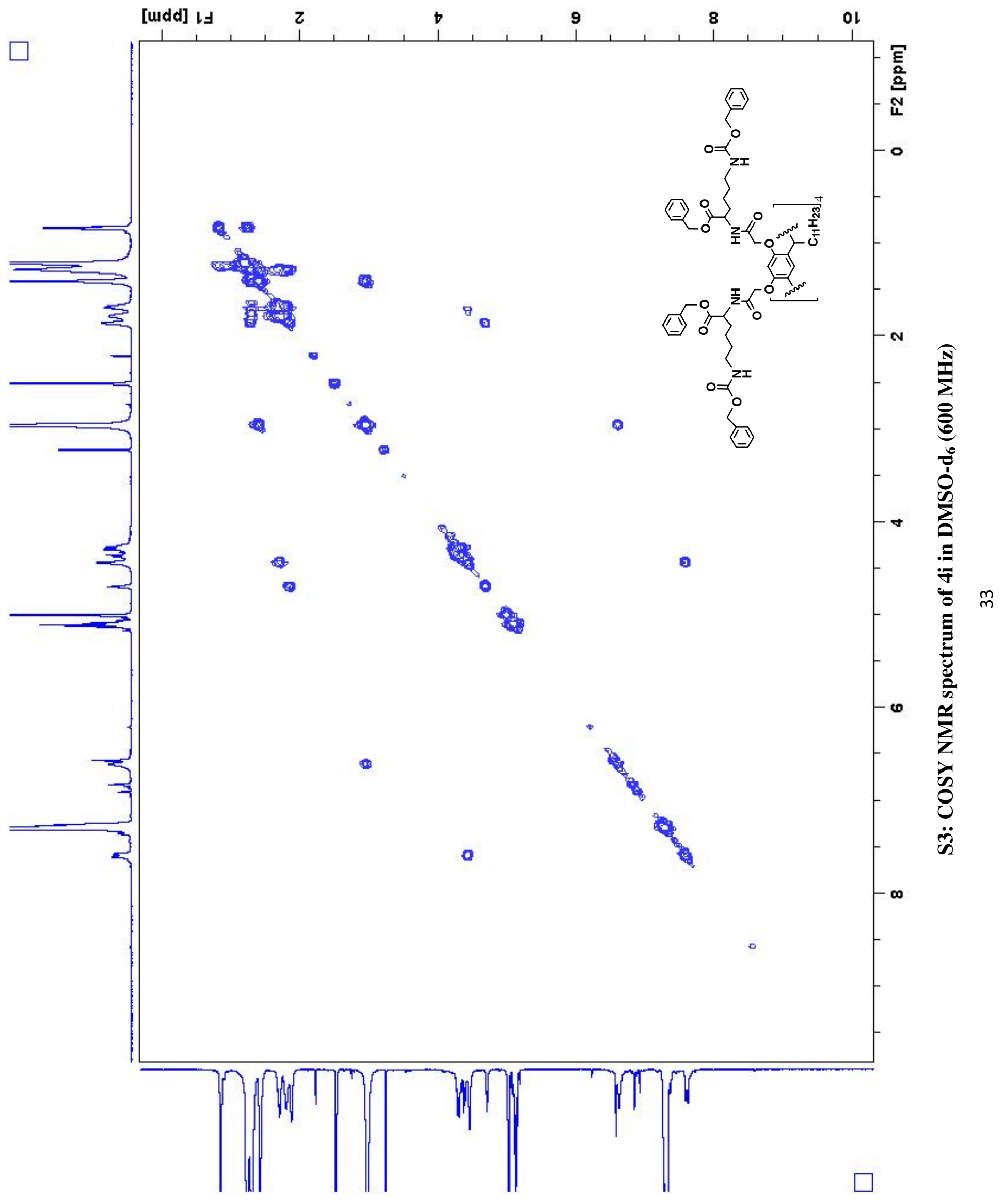




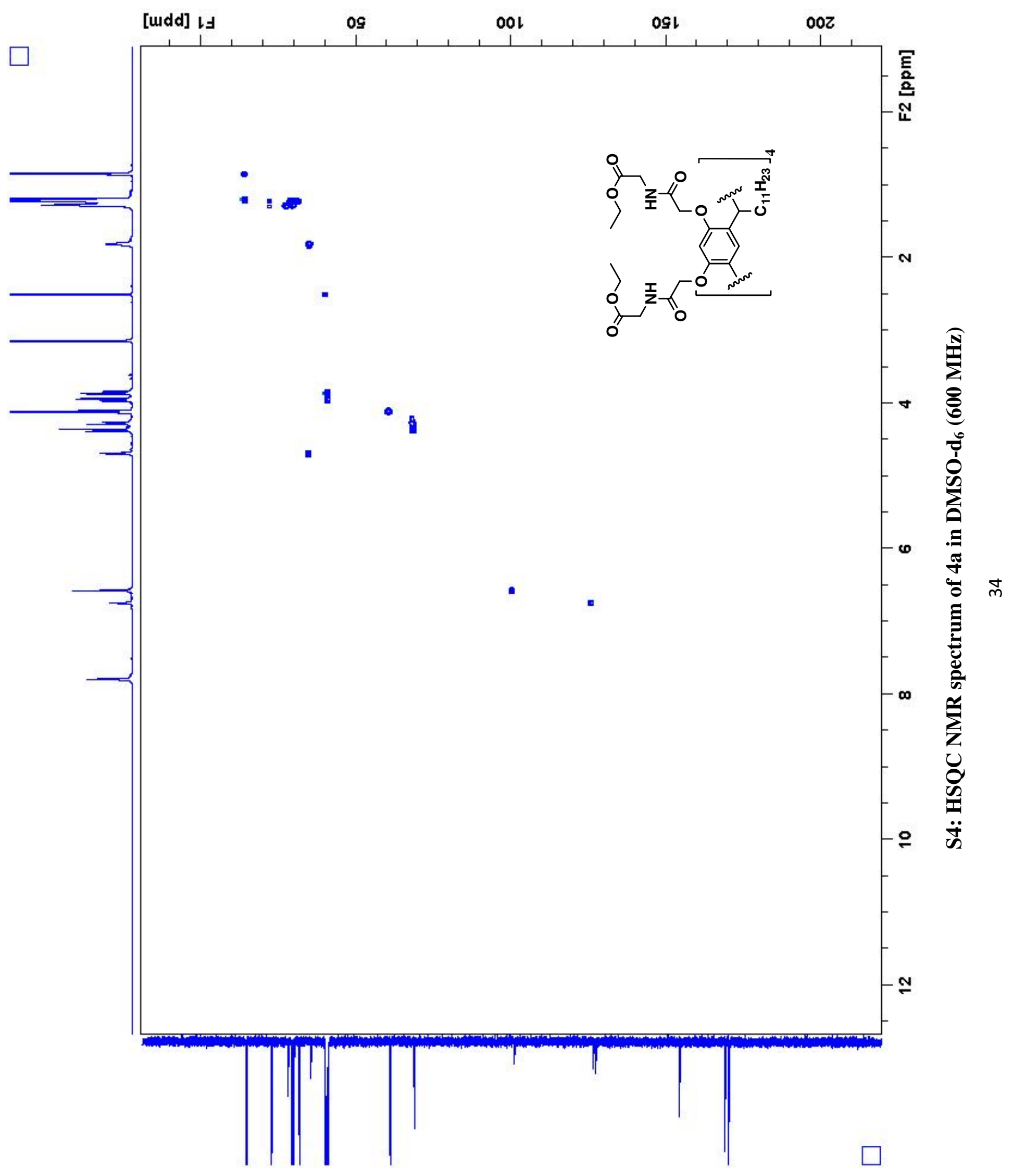




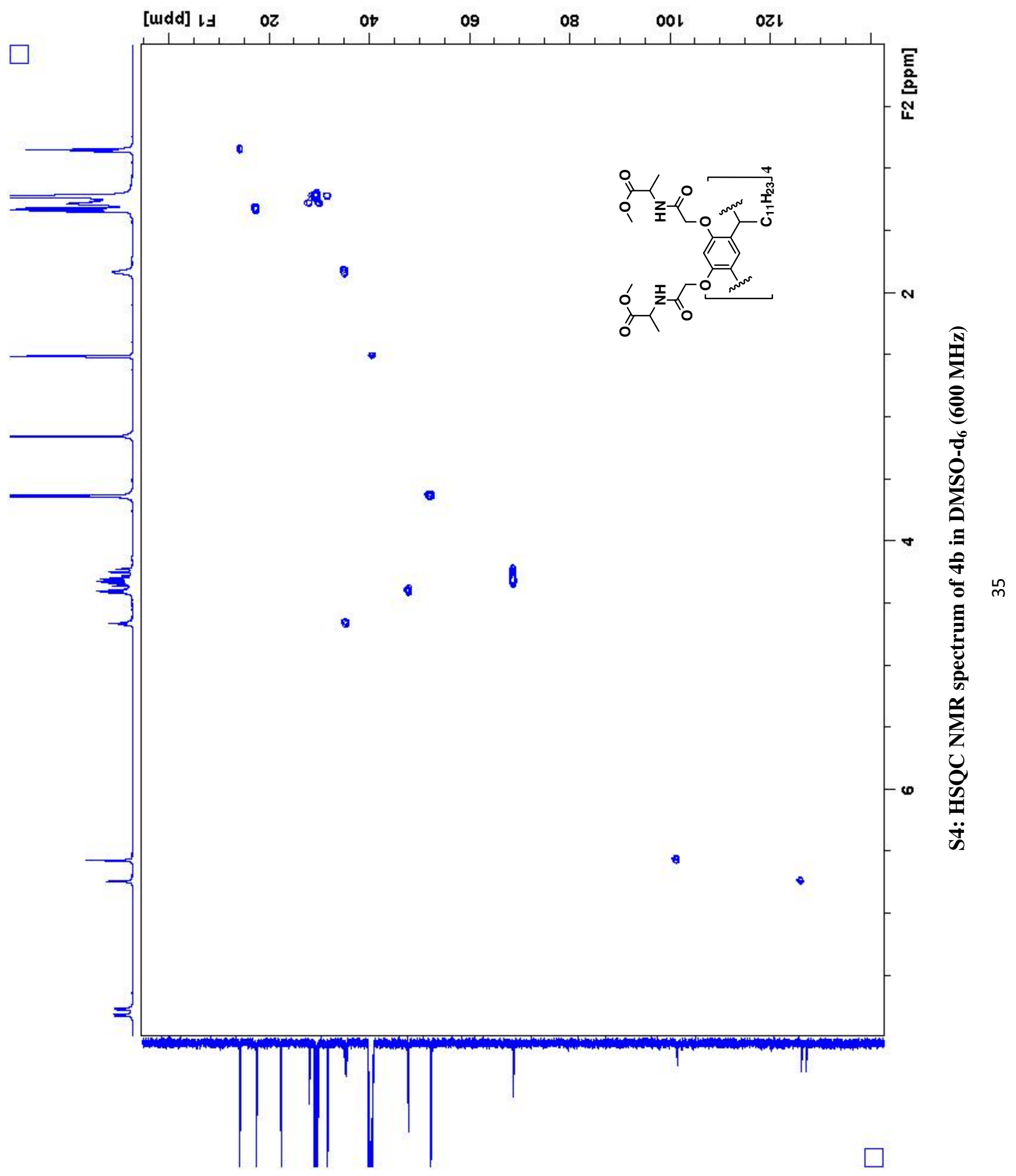




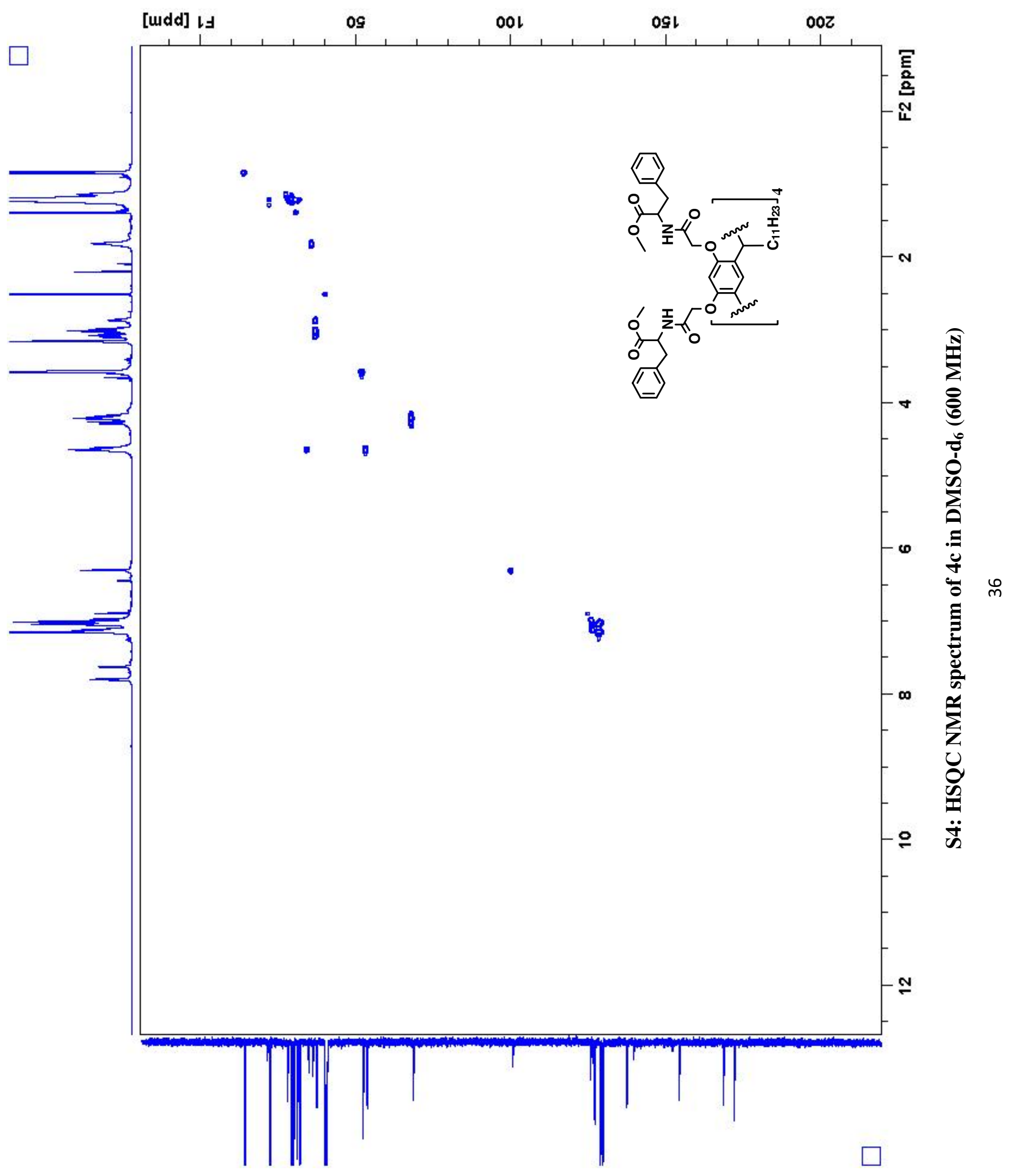




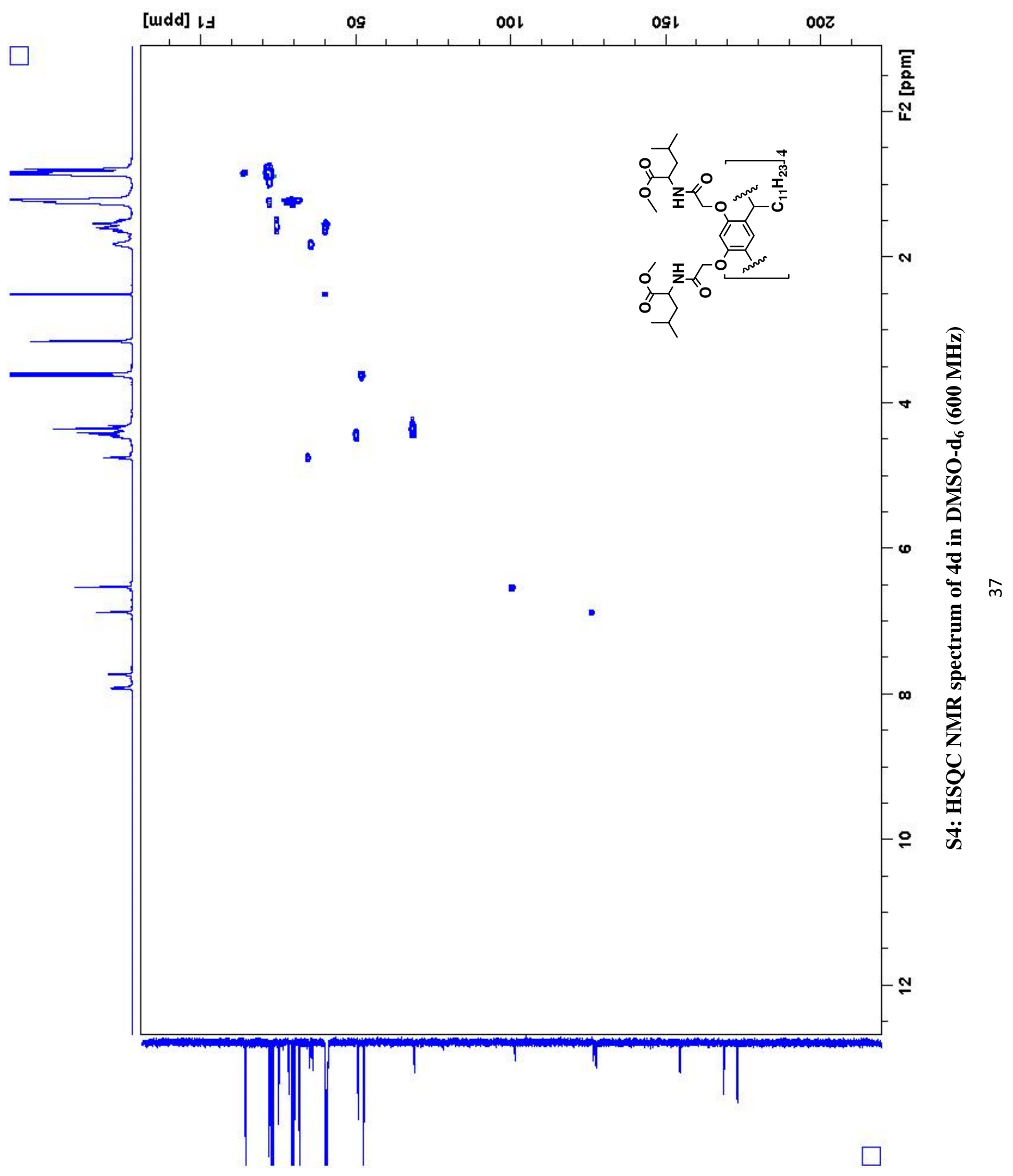




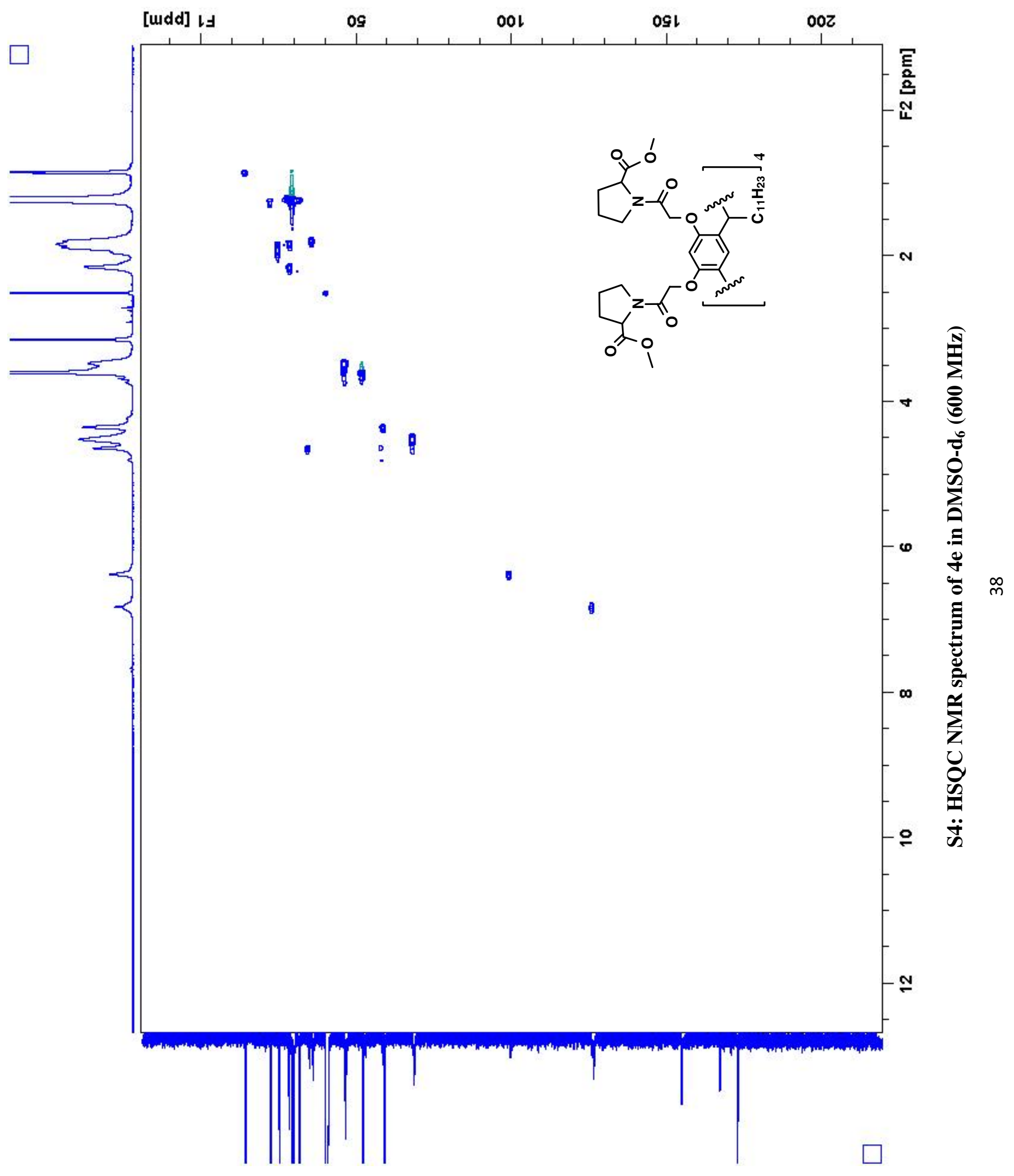




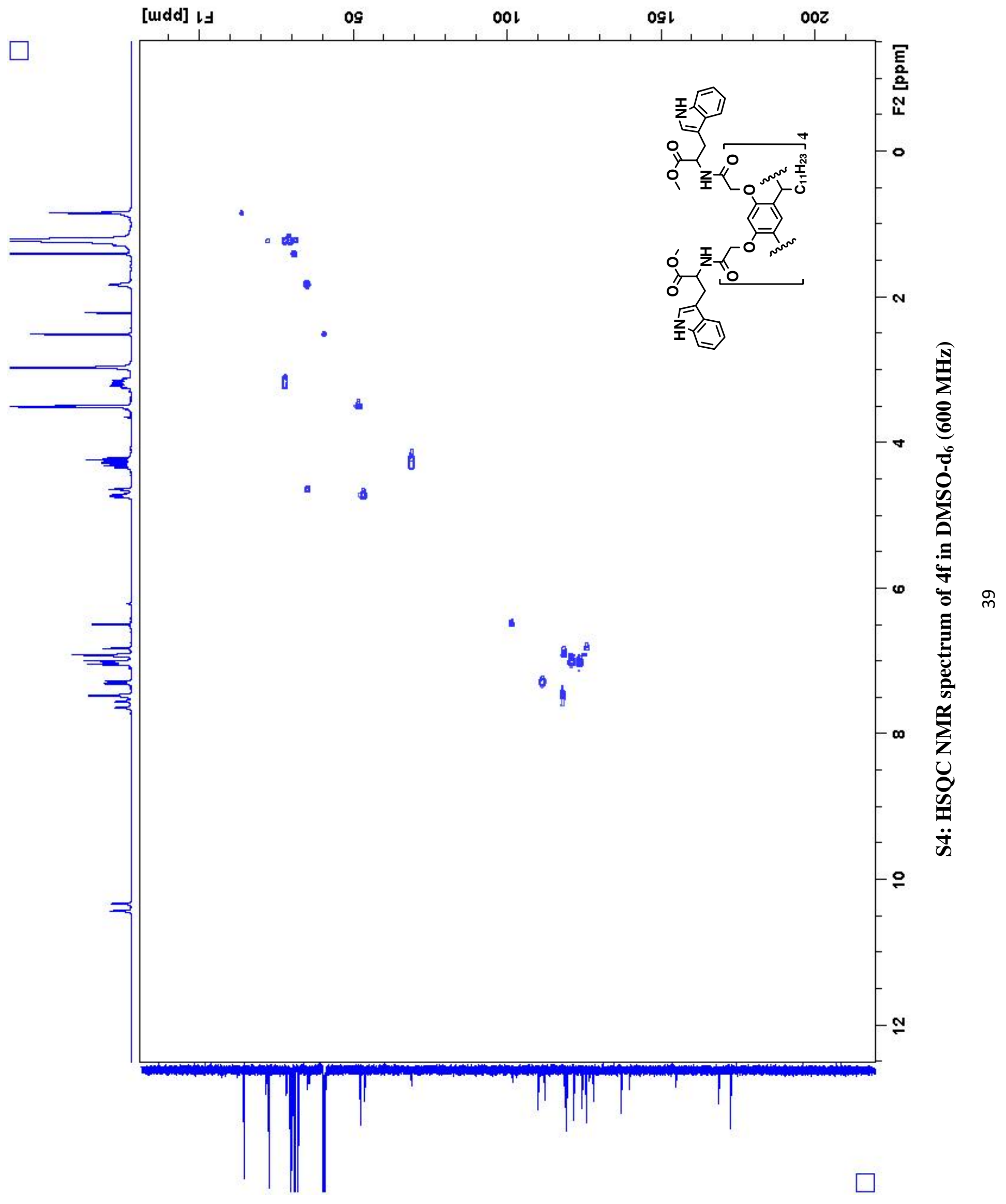




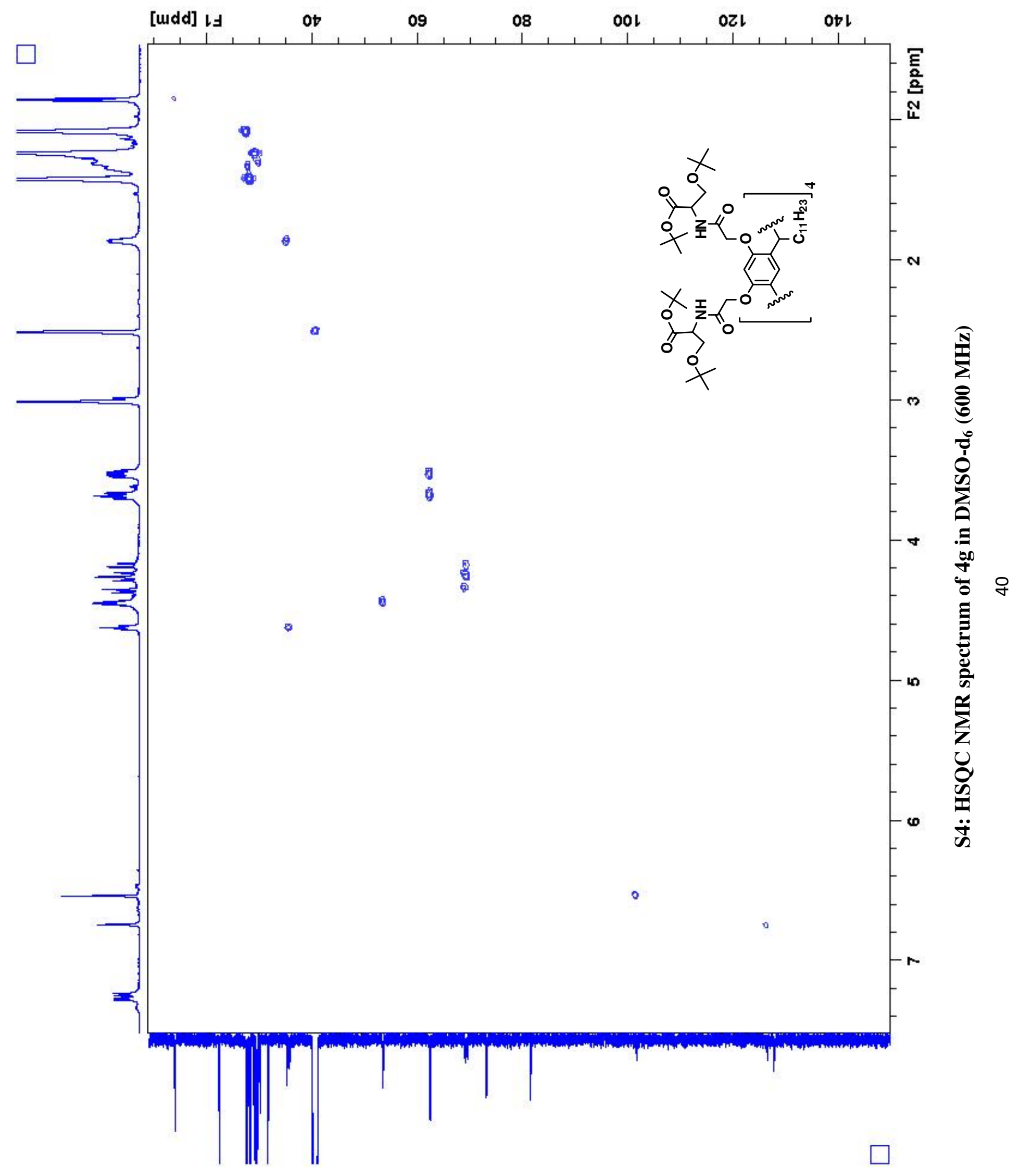




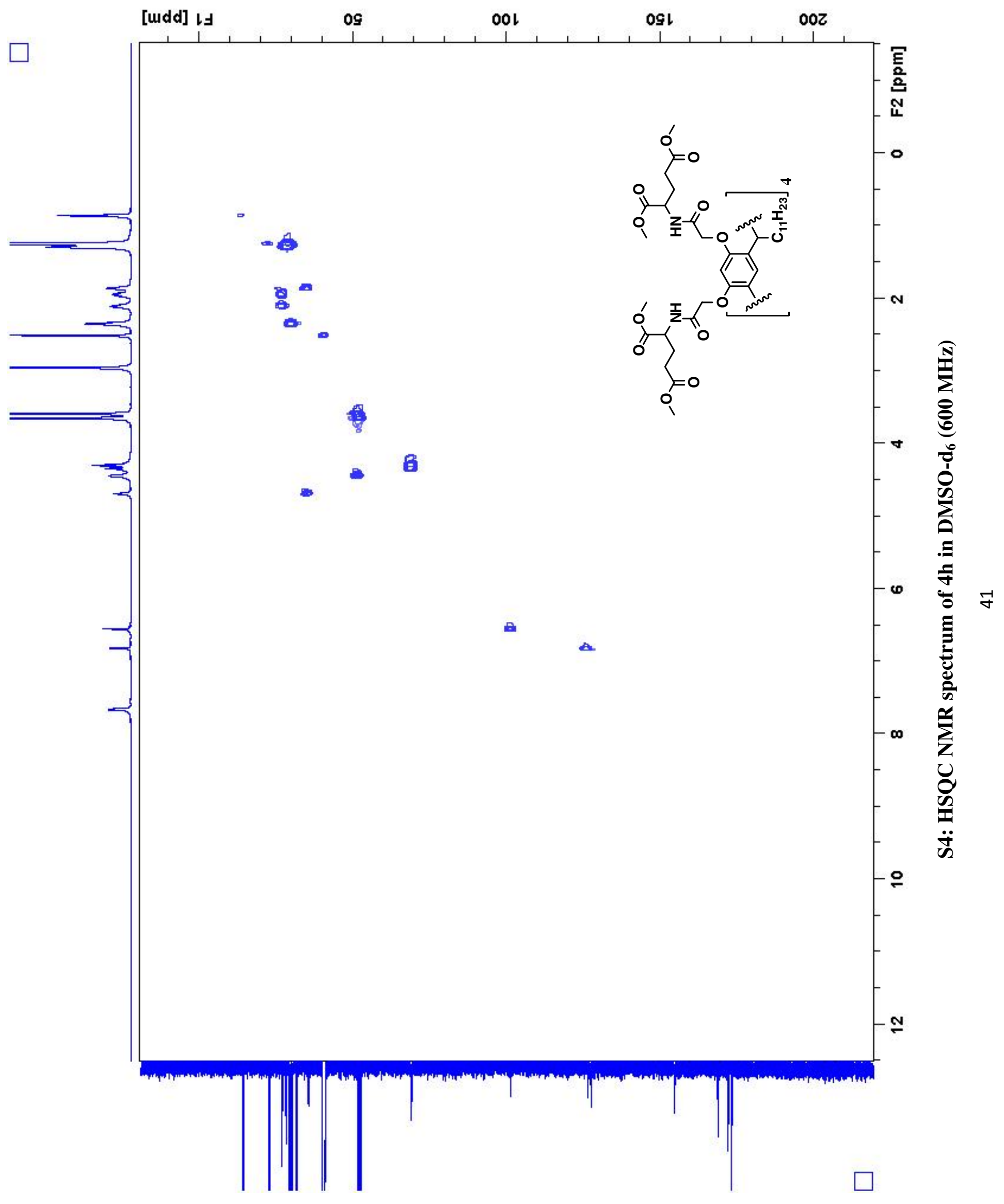




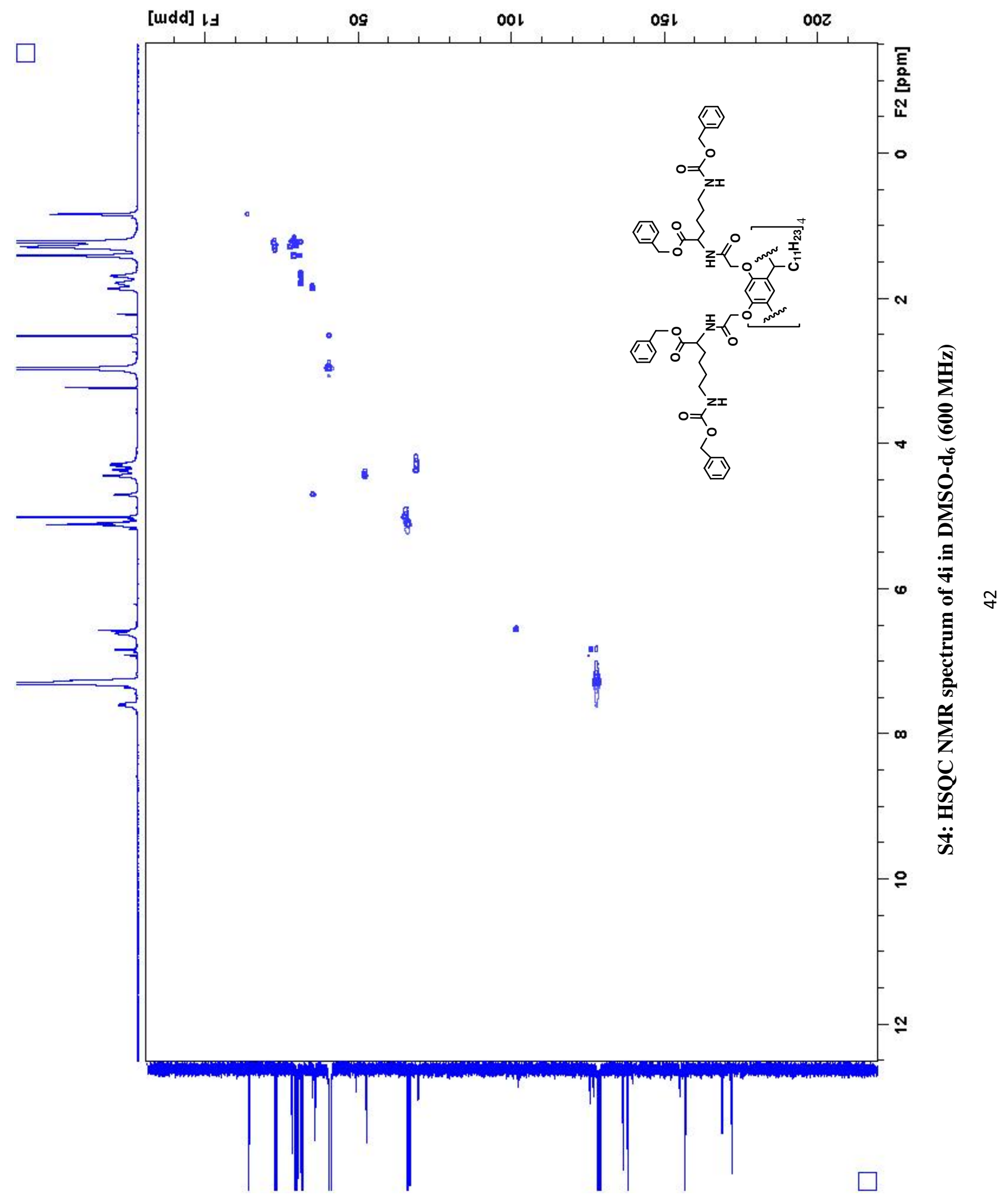




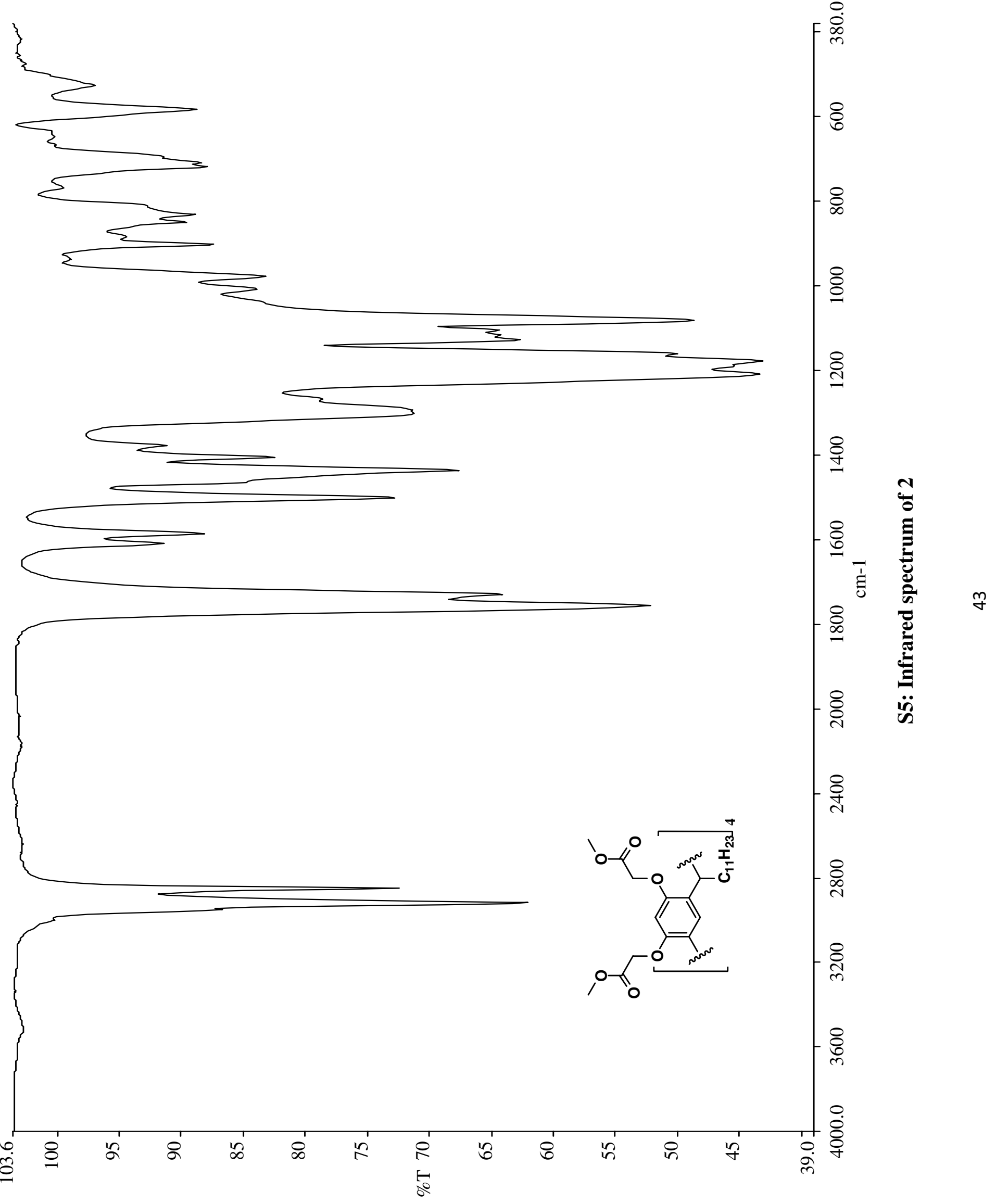




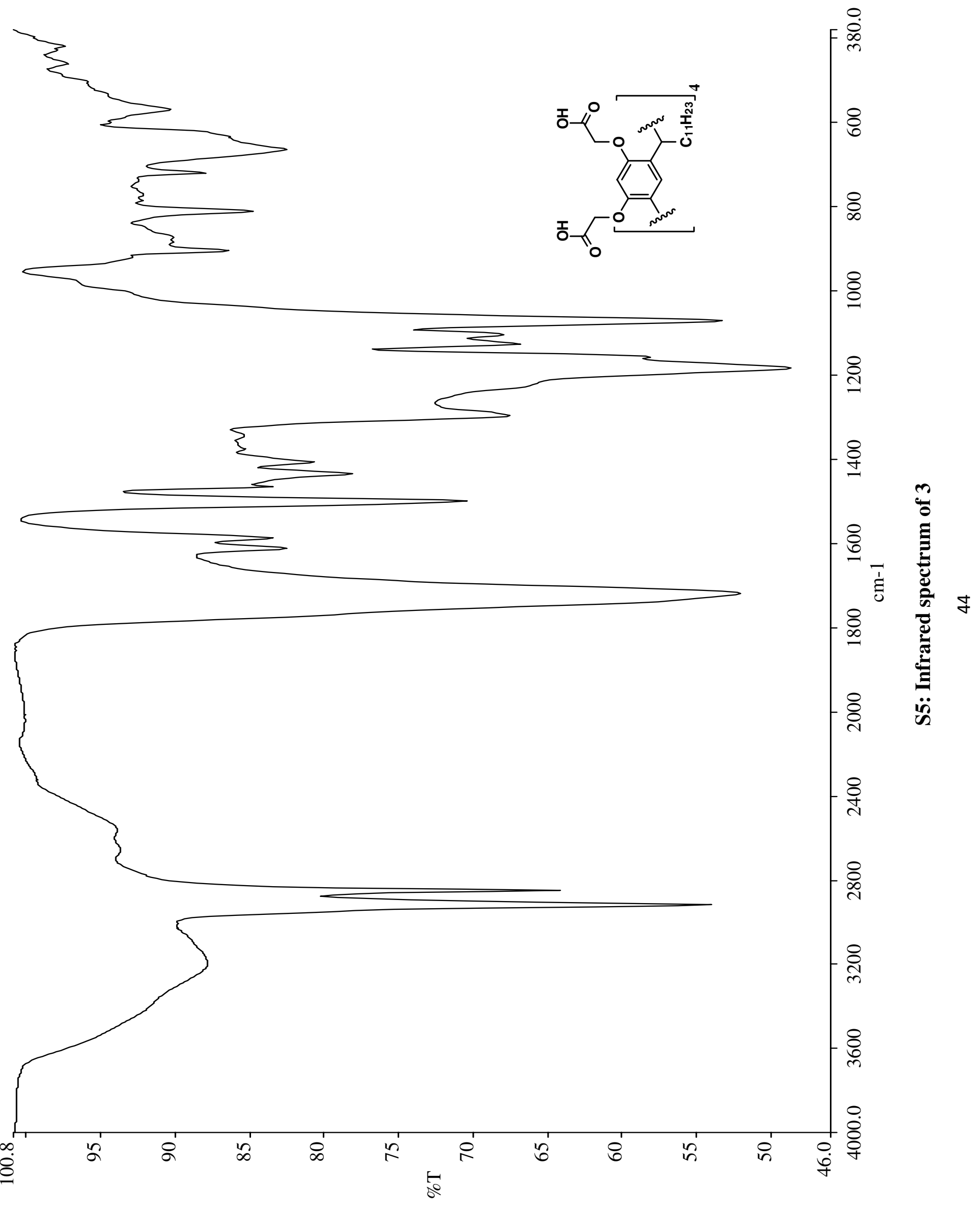




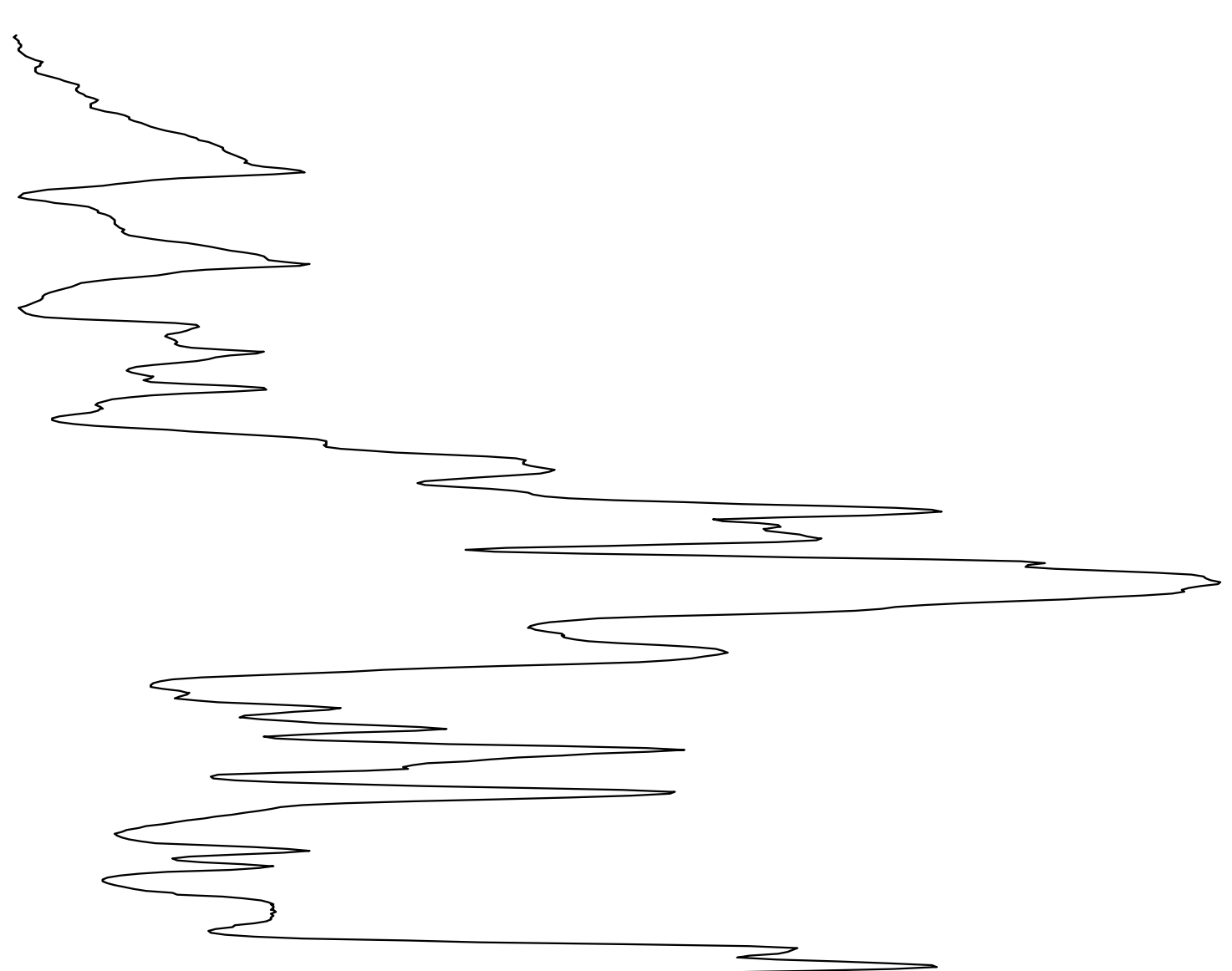

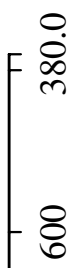

$\stackrel{8}{\infty}$

\&

$-8$

-

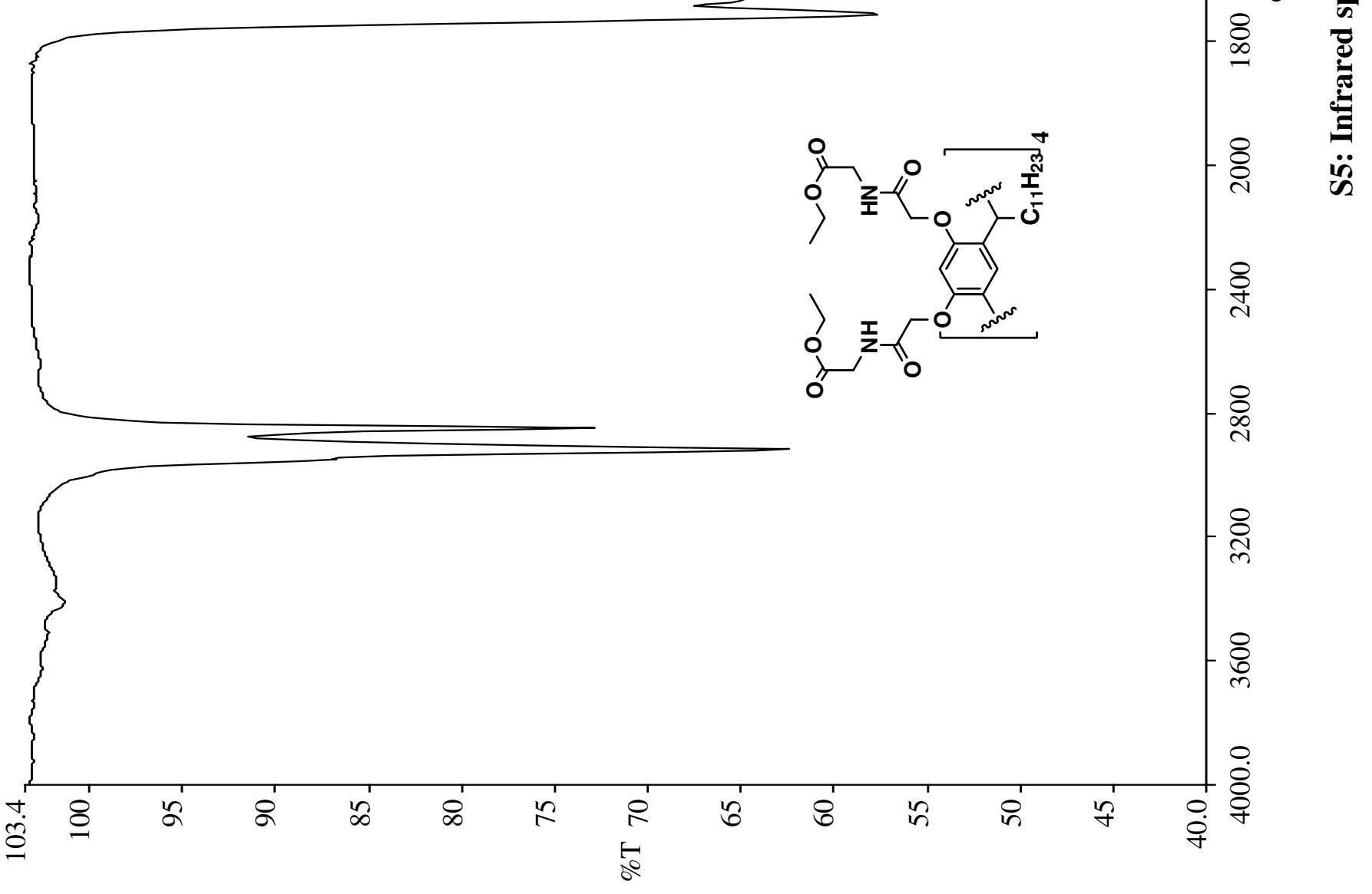




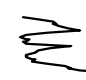

0
0
0
0
-8

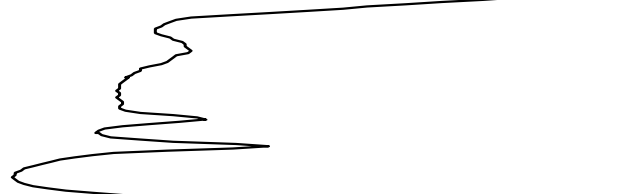

ஓ

8
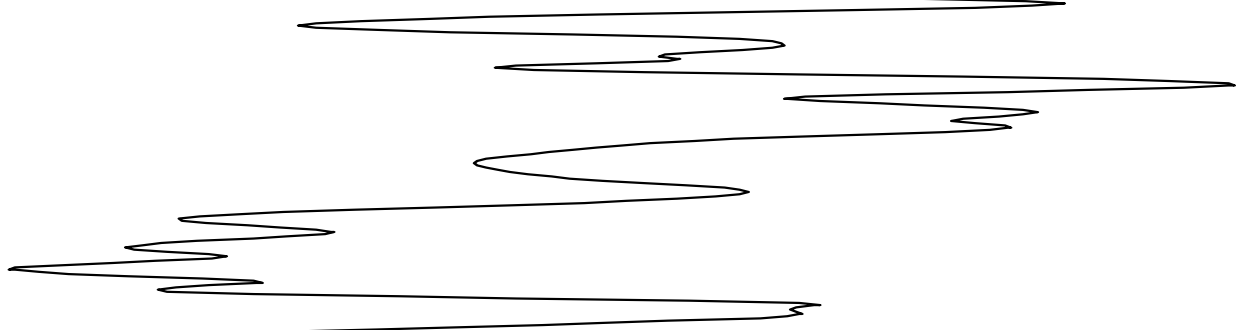

용

용

$\Longrightarrow$

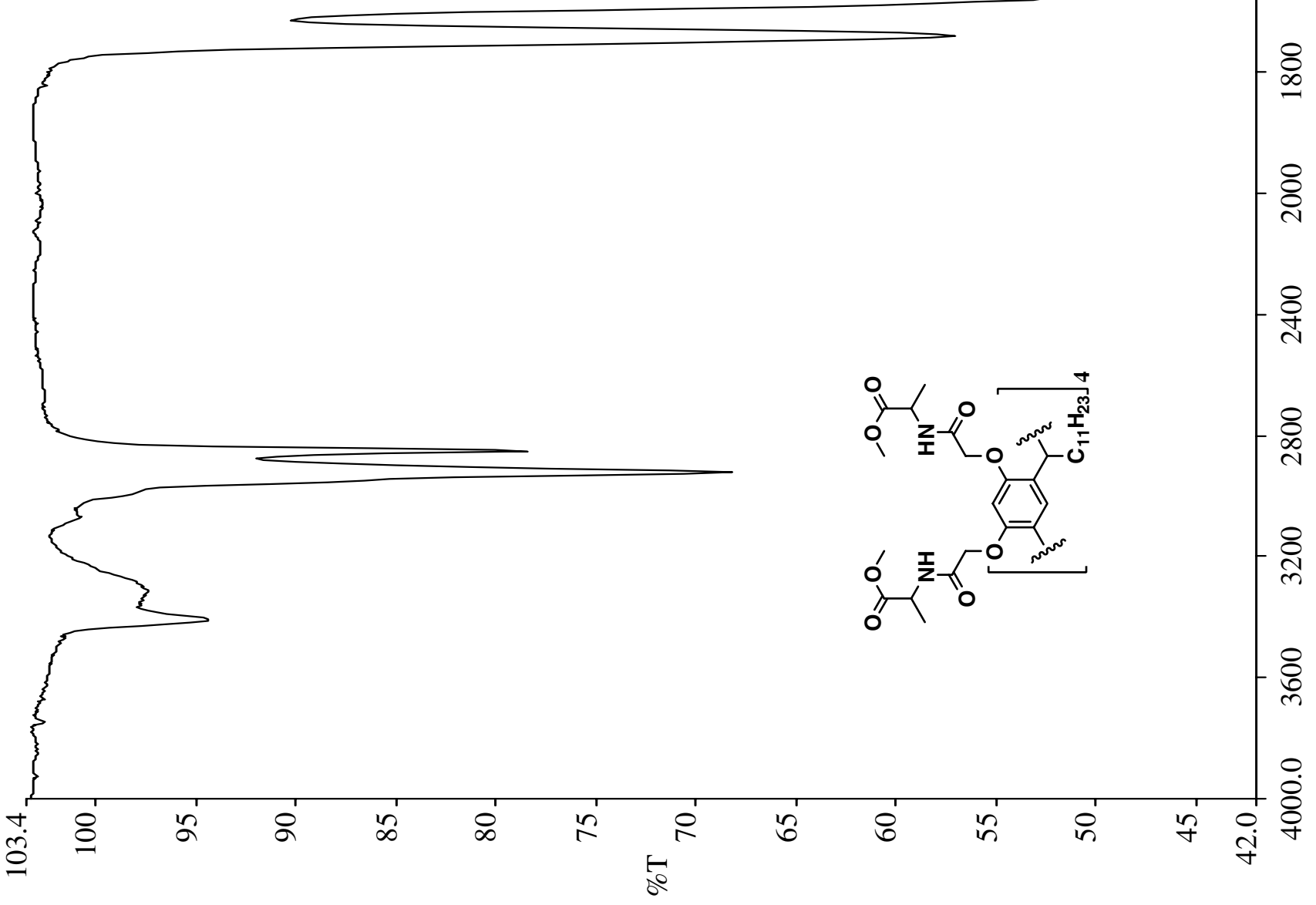

泉

¿্ণ

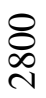

ำ

융

ᄋ̊. 


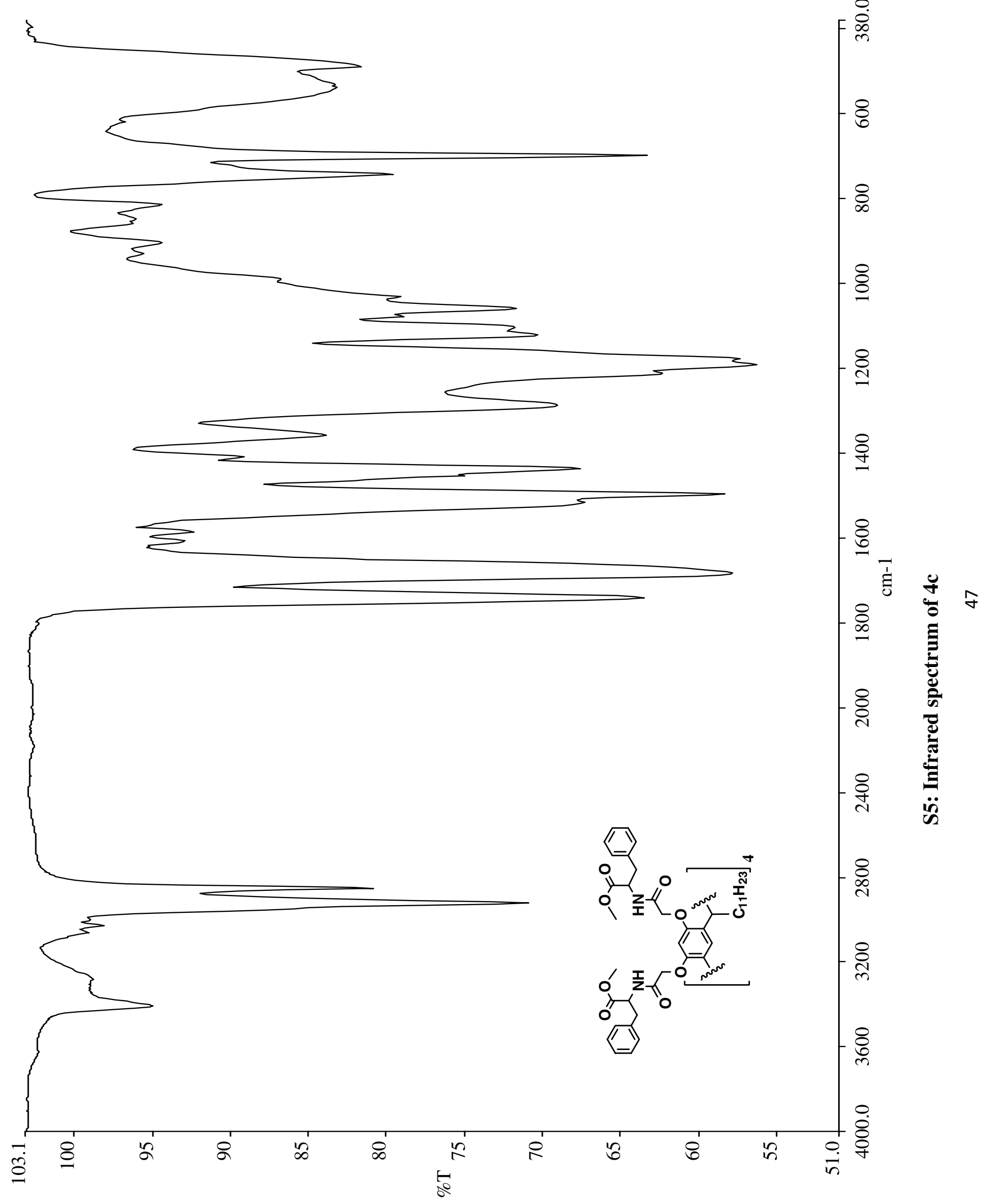


$\gtreqless$
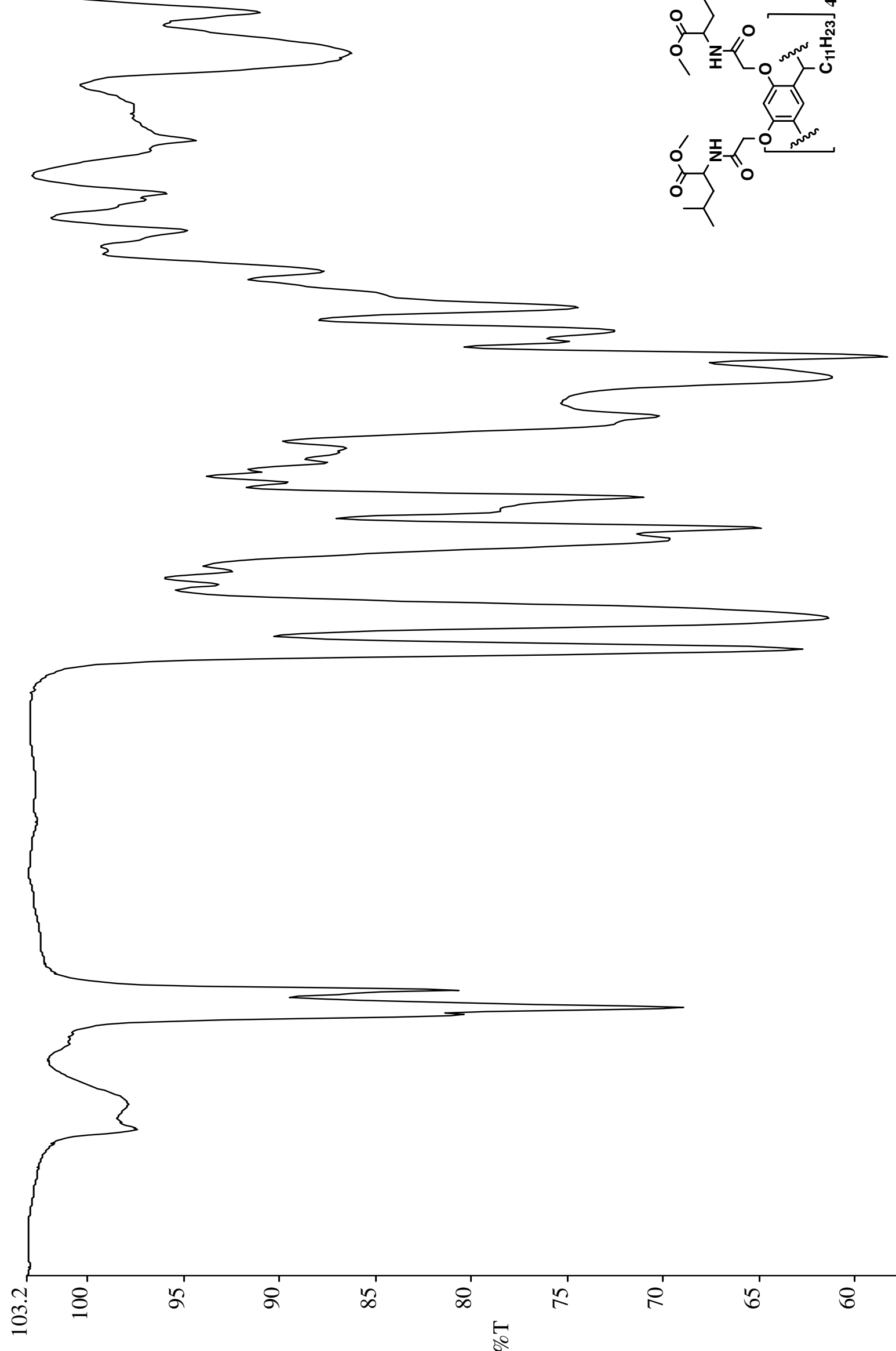


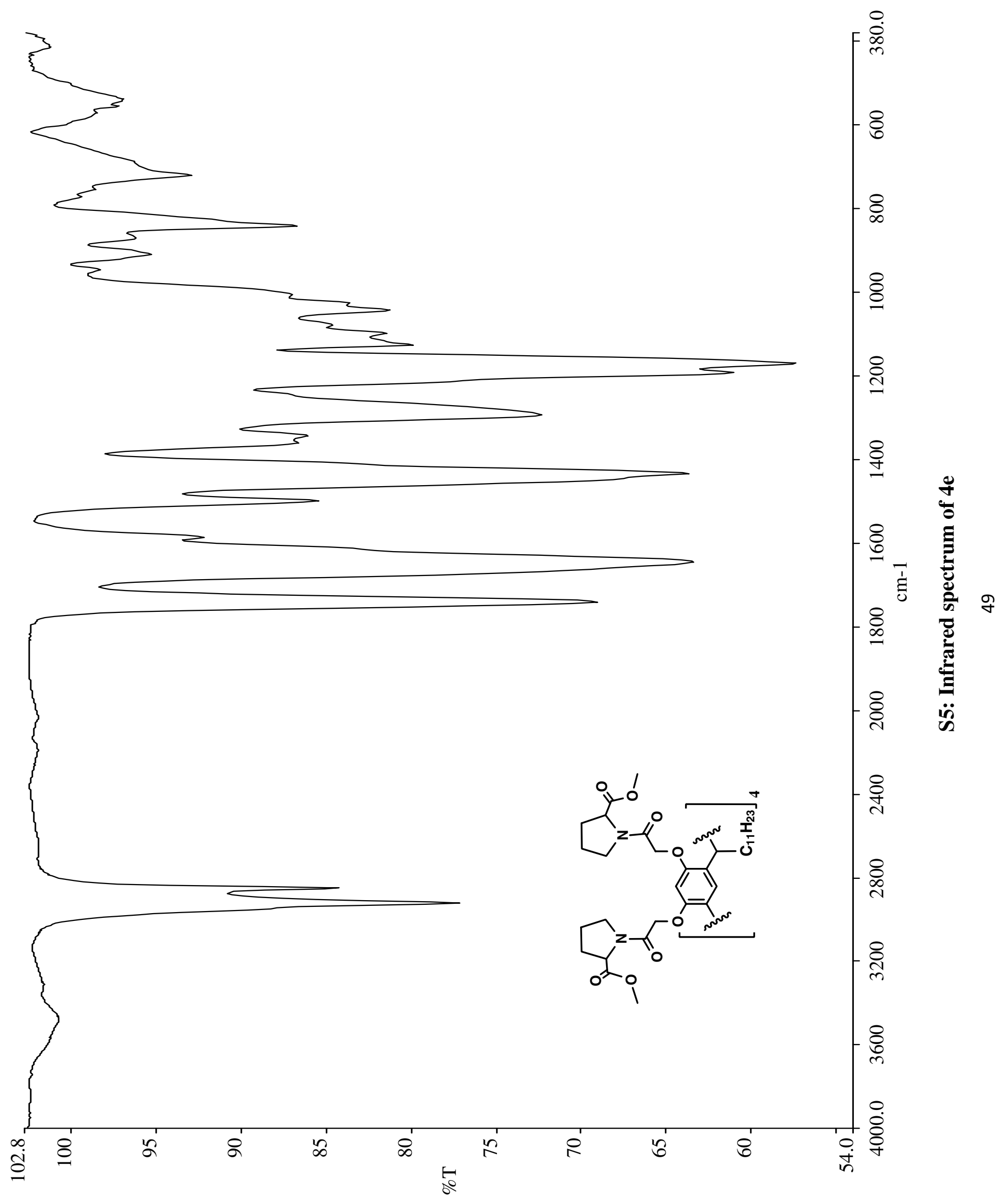




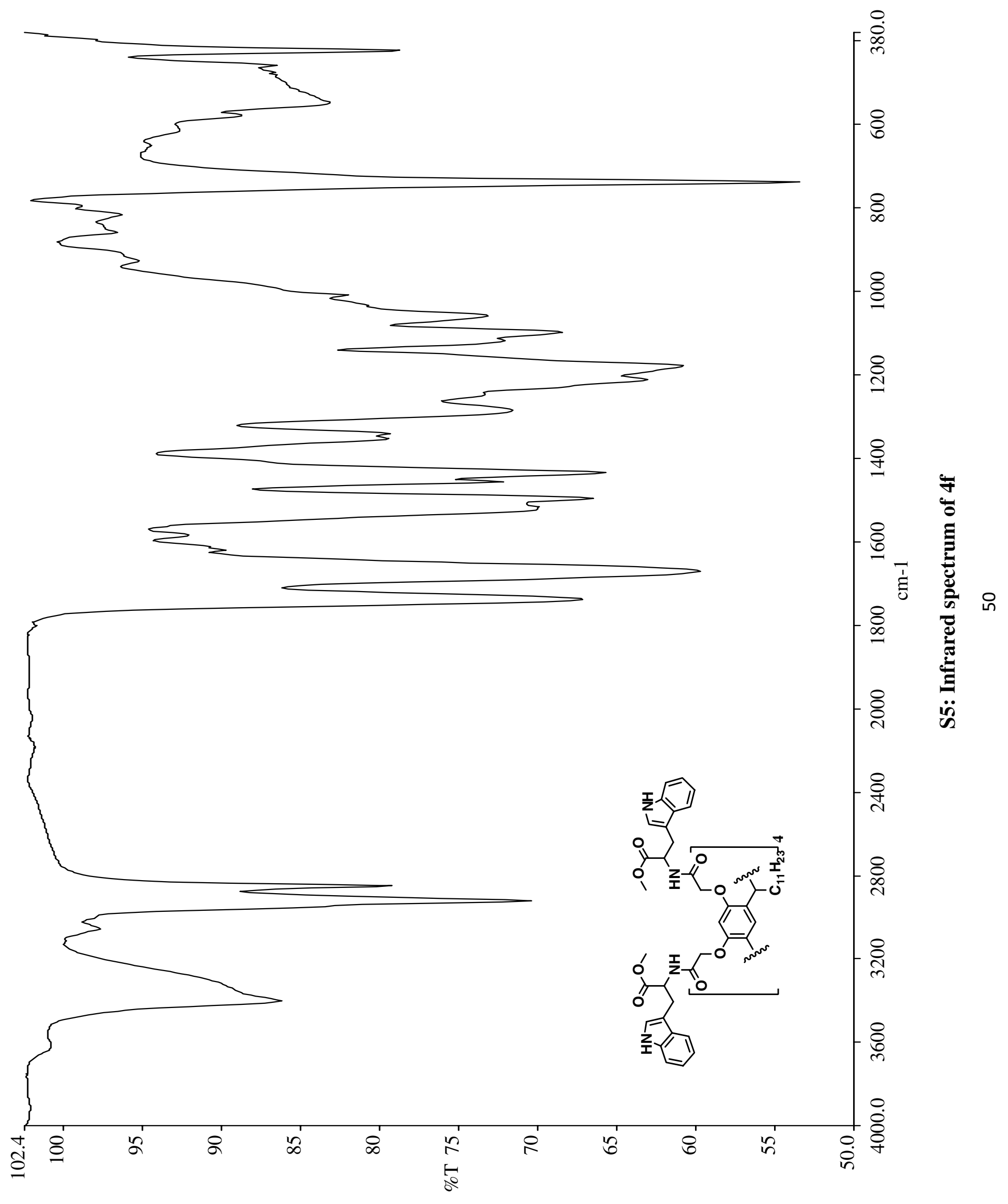




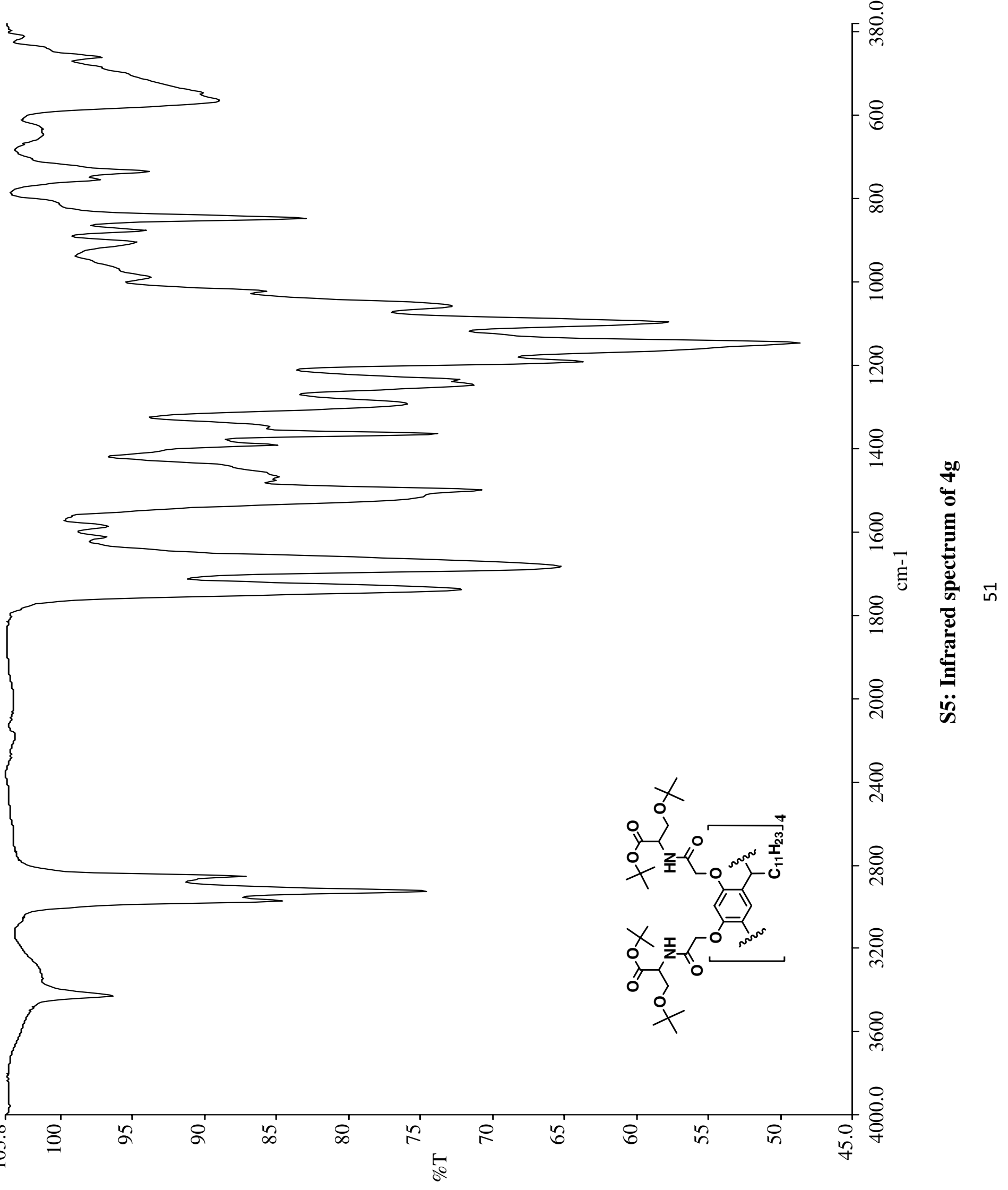




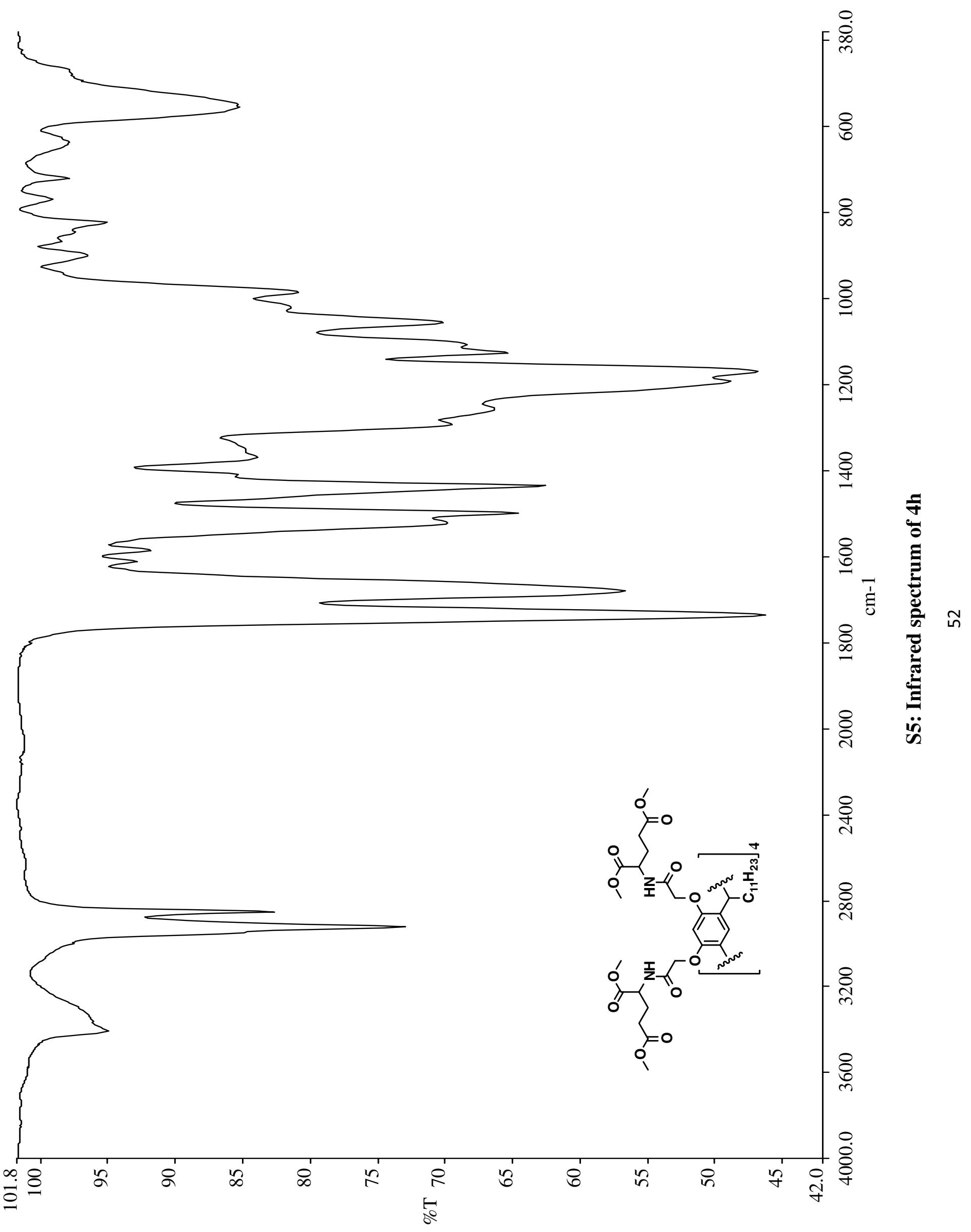




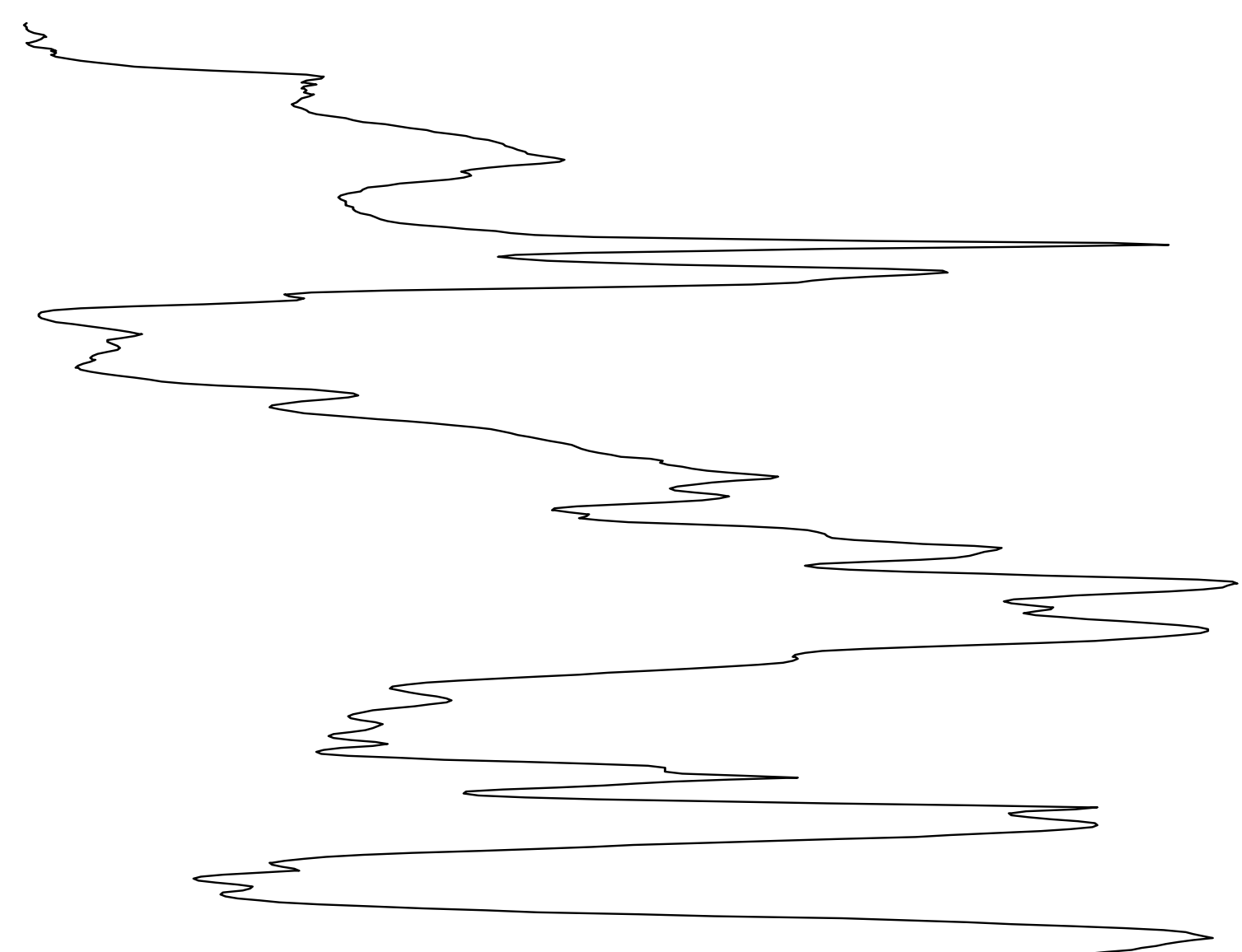

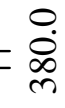

8

ஓ

8

임

요

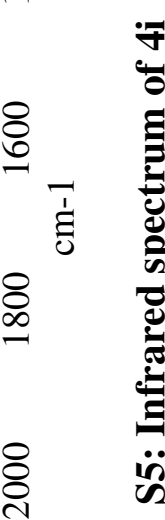
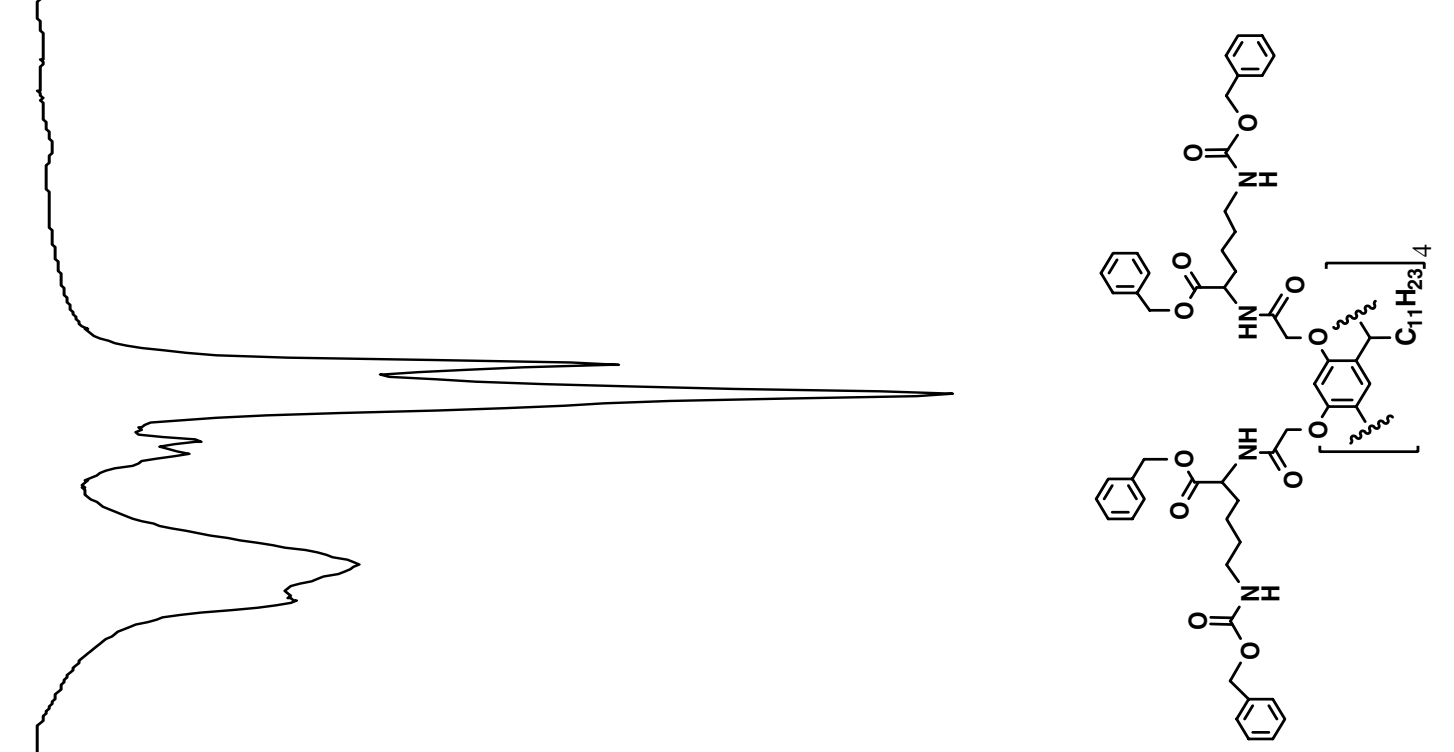

웜
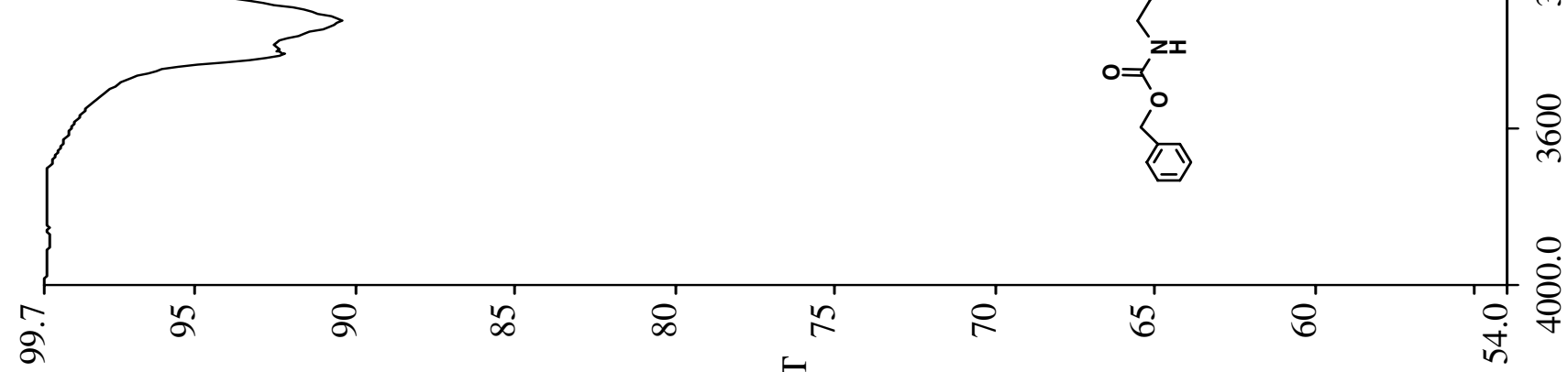

요

๙ัర

8 


\section{NMR Elucidation of compounds}

Characterization of compound 1 was completed using proton $\left({ }^{1} \mathrm{H}\right)$ and carbon $\left({ }^{13} \mathrm{C}\right)$ NMR. The ${ }^{1} \mathrm{H}$ NMR chemical shifts for this compound were assigned with reference to Figure 1.

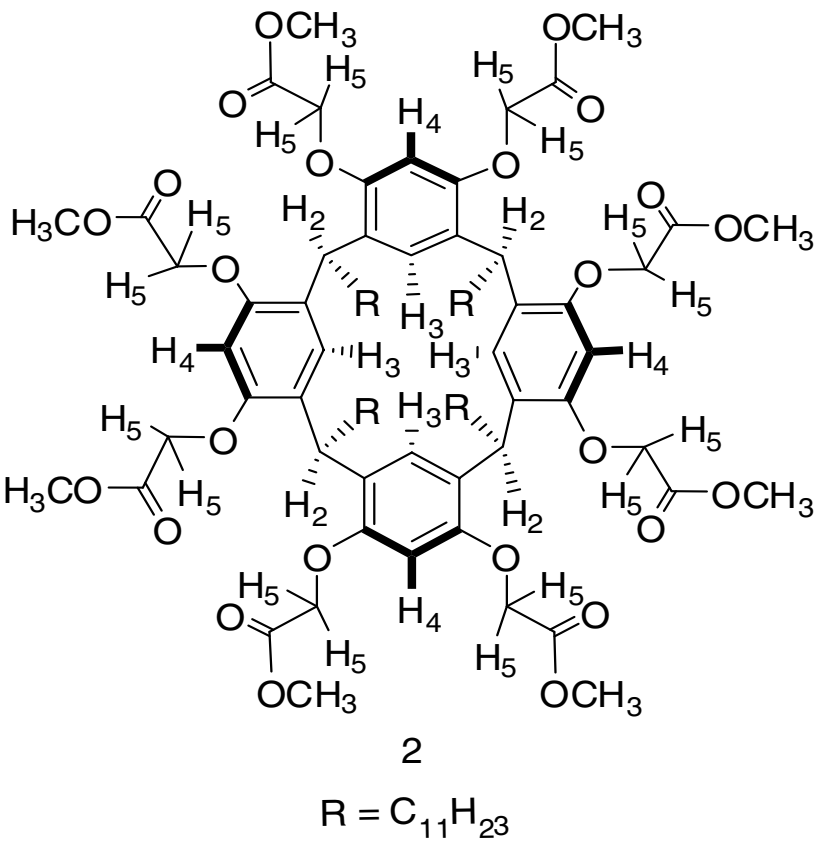

Figure 1: Expanded structure of 2, showing distinctive protons.

Alkylation of the eight hydroxyl groups in $\mathbf{1}$ with methyl-2-bromoacetate afforded $\mathbf{2}$, which result in the appearance of a singlet at $4.30 \mathrm{ppm}$ due to the methylene protons of $\mathrm{OCH}_{2} \mathrm{CO}$ group $\left(\mathrm{H}_{5}\right.$, Figure 2), integrating to sixteen. This signal appears at a lower frequency due to the deshielding nature of the neighbouring oxygen atom and carbonyl group. The signals associated with the methoxy groups appear as a singlet at $3.77 \mathrm{ppm}$, integrating to twenty four. The signals related to the two aromatic resorcin[4]arene protons appear as a singlet at $6.58 \mathrm{ppm}$ for $\mathrm{H}_{3}$ protons (meta to the hydroxyl groups) and at $6.20 \mathrm{ppm}$ due to the $\mathrm{H}_{4}$ protons (ortho to the hydroxyl group), each of these signals integrating to four. The proton signal of $\mathrm{H}_{3}$ appears at a lower frequency compared to the $\mathrm{H}_{4}$ protons. The signal related to the methine protons $\left(\mathrm{H}_{2}\right)$ which bridge the aromatic moieties, appears as a triplet at $4.57 \mathrm{ppm}$, integrating to four. The signals associated with the undecyl "feet" (R) give rise to a quartet at $1.90 \mathrm{ppm}$ (integrating to eight), a multiplet at 1.20-1.30 ppm (integrating to seventy two), and a triplet at $0.87 \mathrm{ppm}$ (integrating to twelve) due to the terminal methyl groups of the "feet". The two singlet peaks at $6.58 \mathrm{ppm}$ and $6.20 \mathrm{ppm}$ for $\mathrm{H}_{3}$ and $\mathrm{H}_{4}$ protons, respectively, indicate the symmetric positions of these protons in a crown $\left(\mathrm{C}_{4 v}\right)$ conformation. $(1,2)$

Subsequent hydrolysis of compound 2 using a potassium hydroxide solution ( $2 \mathrm{M} \mathrm{KOH}$ ) in ethanol under reflux for 3 hours (Scheme 1, main paper), gave 3 in 93\% yield after re-crystallisation from methanol/water in a 1:1 ratio.(3) Compound 3 was characterised from its proton and carbon NMR spectra. The ${ }^{1} \mathrm{H}$ NMR chemical shifts for this compound were assigned with reference to Figure 2. 


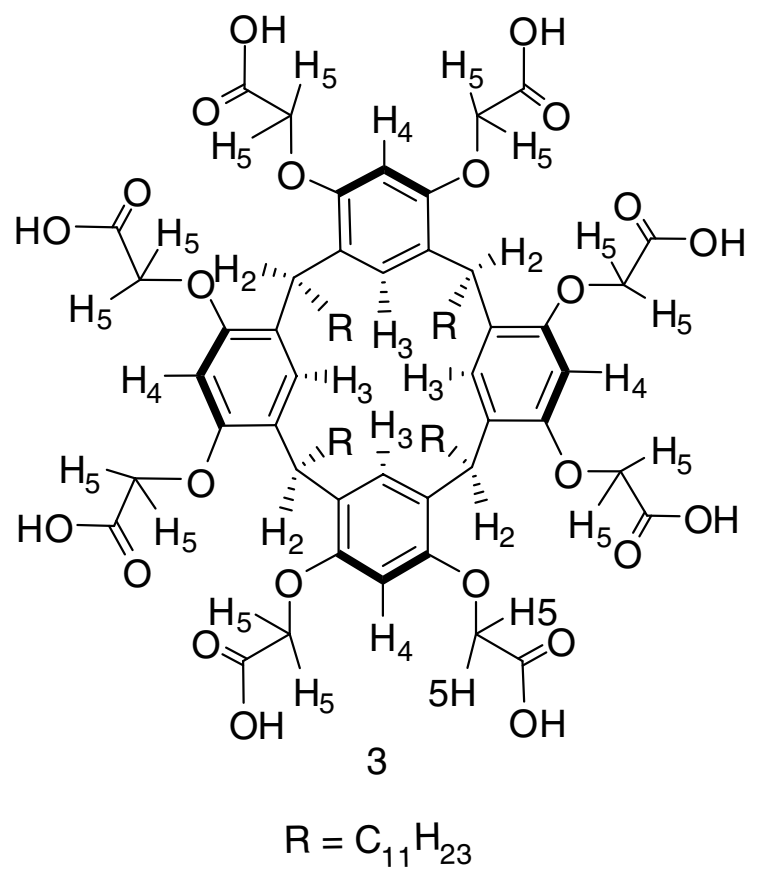

Figure 2: Expanded structure of 3, showing distinctive protons.

Hydrolysis of 2 confirmed by the disappearance of the methoxy group signal (singlet at $3.77 \mathrm{ppm}$ ) in $\mathbf{3}$. The signal associated with the methylene protons of $\mathrm{OCH}_{2} \mathrm{CO}\left(\mathrm{H}_{5}\right.$, Figure 3) appears as a pair of doublets at $4.23 \mathrm{ppm}$ and $4.41 \mathrm{ppm}$, each of these signals integrates to eight. Compared to the singlet signal for the methylene protons for 2 in non-polar solvent $\left(\mathrm{CDCl}_{3}\right)$, this splitting clearly shows that in polar organic solvent (DMSO), there is weak intramolecular hydrogen bonding. The signals related to the two aromatic resorcin[4]arene protons $\left(\mathrm{H}_{3}\right.$ and $\left.\mathrm{H}_{4}\right)$ appear as a slightly broad singlet (compared to the aromatic protons signals for 2 in $\mathrm{CDCl}_{3}$ ). One appears at $6.49 \mathrm{ppm}$ for $\mathrm{H}_{3}$ protons and the other at 6.20 ppm due to the $\mathrm{H}_{4}$ protons, each of these integrates to four. The signal associated with the methine protons $\left(\mathrm{H}_{2}\right)$ appears as a triplet at $4.48 \mathrm{ppm}$, integrating to four. The signals related to the "feet" have resolved into three signals: a quartet at 1.75 ppm, multiplets at 1.20-1.29 ppm, and a triplet at 0.82ppm. These signals maintain their associated integration.

The appearance of the methylene protons $\left(\mathrm{H}_{5}\right)$ as two doublets and the slight broadening of the two aromatic protons $\left(\mathrm{H}_{3}\right.$ and $\mathrm{H}_{4}$ ), show that compound $\mathbf{3}$ is flexible and mainly exists in a boat conformation with $\mathrm{C}_{4 v}$ symmetry on NMR time scale. 


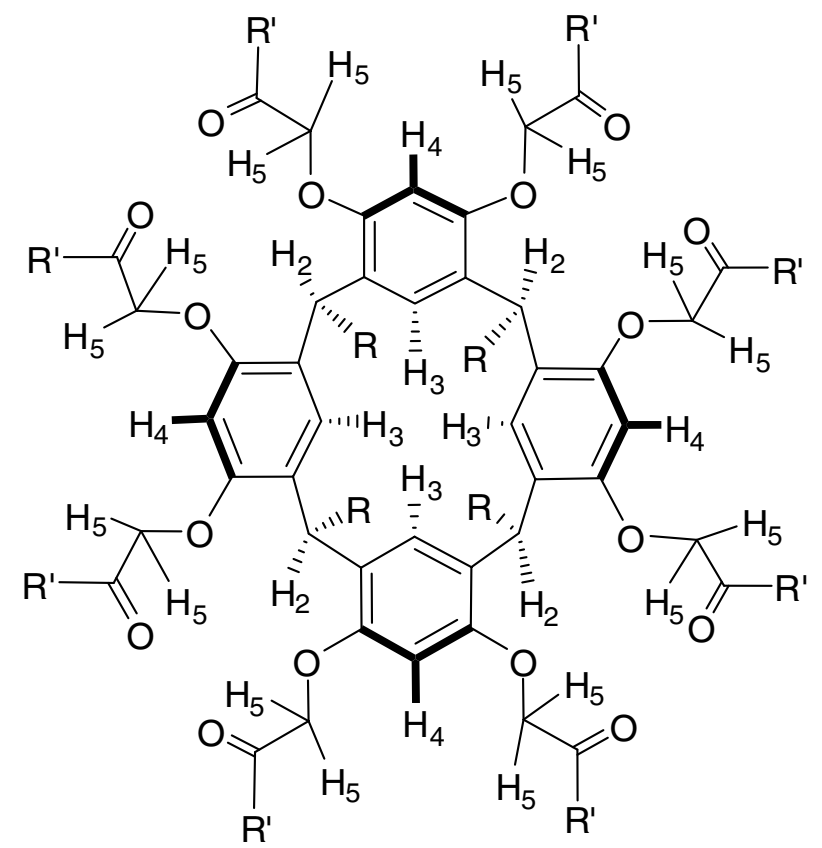

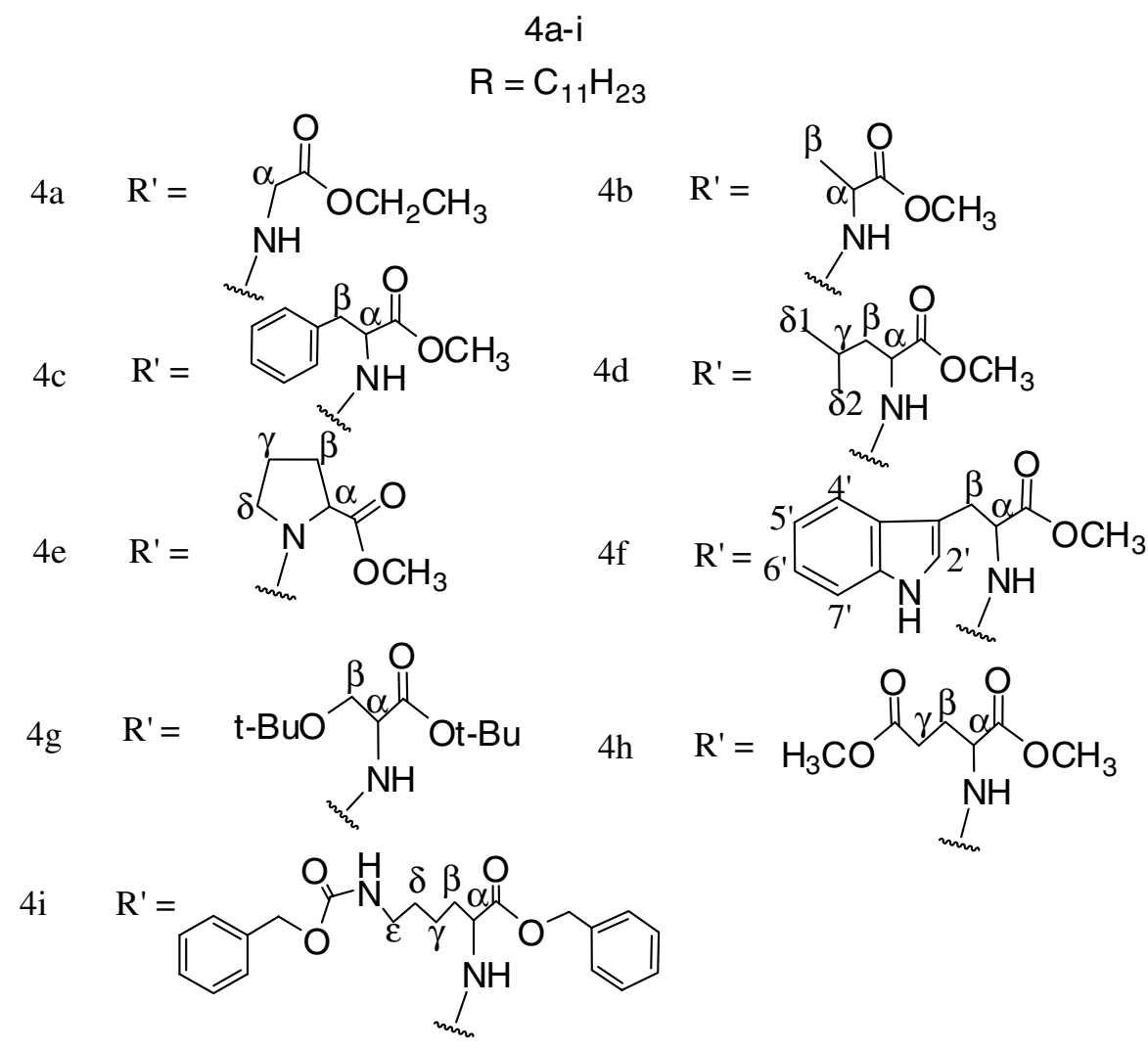

Figure 3: Expanded structure of 4a-i, showing distinctive protons.

The ${ }^{1} \mathrm{H}$ NMR spectrum for $\mathbf{4 b}$ displays signals characteristic for both units. The signal associated with the methyl protons of the ester group appears as a doublet at $3.64 \mathrm{ppm}$, integrating to twenty four. The signal related to the alanine $\alpha$-protons appears as a quartet at $4.42 \mathrm{ppm}$, integrating to eight. The signal due to the methyl group attached to the $\beta$-carbon appears as a triplet at $1.34 \mathrm{ppm}$, integrating to twenty four. The amide $\mathrm{NH}$ protons signal for this derivative appears as two doublets at $7.82 \mathrm{ppm}$ and $7.80 \mathrm{ppm}$, each integrating to four.

The signal for the methylene protons of the $\mathrm{OCH}_{2} \mathrm{CO}$ groups $\left(\mathrm{H}_{5}\right)$ appears as a pair of quartets at $4.35 \mathrm{ppm}$ and $4.24 \mathrm{ppm}$, each of these integrates to eight. This splitting could be attributed to the presence of two chiral amino acid units on each 
aromatic ring making these protons $\left(\mathrm{H}_{5}\right)$ diastereotopic. $(4,5)$ The signals for the aromatic ring protons $\left(\mathrm{H}_{3}\right.$ and $\left.\mathrm{H}_{4}\right)$ appear as two singlets in the ${ }^{1} \mathrm{H}$ NMR spectrum, one at $6.73 \mathrm{ppm}$ (for $\mathrm{H}_{3}$ ), and the other at $6.56 \mathrm{ppm}\left(\right.$ for $\mathrm{H}_{4}$ ). The signal for the $\mathrm{H}_{2}$ protons at $4.67 \mathrm{ppm}$ is a triplet, integrating to four. The signal related to the undecyl "feet" (R, Figure 3) is largely unchanged from $\mathbf{4 a}$, and maintains the associated multiplicity and integration.

Coupling of L-phenyl alanine methyl ester to the octa-acyl chloride resorcin[4]arene $\mathbf{3}$ afforded compound $\mathbf{4 c}$ in $71 \%$ yield. The ${ }^{1} \mathrm{H}$ NMR spectrum exhibits signals for the phenyl alanine residue and the resorcin[4]arene scaffold. The signal associated with the methyl protons of the ester group at $3.59 \mathrm{ppm}$ is a doublet, integrating to twenty four. The signal associated with the $\alpha$-protons at $4.64 \mathrm{ppm}$ appears as a quartet, integrating to eight. The signal associated with the $\beta$ protons splits into four pairs of doublets at $3.11 \mathrm{ppm}, 3.04 \mathrm{ppm}, 3.03 \mathrm{ppm}$, and $2.87 \mathrm{ppm}$ due to coupling with the $\alpha$ protons. Each of these integrates to four. The signals related to the phenyl rings at the side chains appear as a multiplet at 7.04-7.15 ppm, integrating to 40. The amide NH protons signal for this compound appears as two doublets at $7.77 \mathrm{ppm}$ and $7.60 \mathrm{ppm}$, each of these integrates to four.

The signal for the diastereotopic methylene protons of the $\mathrm{OCH}_{2} \mathrm{CO}$ groups $\left(\mathrm{H}_{5}\right)$ appears as a pair of quartets at $4.28 \mathrm{ppm}$ and $4.20 \mathrm{ppm}$, each integrating to eight. The signals related to the aromatic protons appear as two singlets, one at $6.89 \mathrm{ppm}$ related to $\mathrm{H}_{3}$ protons in Figure 7 and the other at $6.33 \mathrm{ppm}$ due to the $\mathrm{H}_{4}$ protons. Each of these integrates to four. The signal related to the $\mathrm{H}_{2}$ protons appears as a triplet at $4.64 \mathrm{ppm}$ and integrates to four. The signals associated with the undecyl "feet" are unchanged.

The ${ }^{1} \mathrm{H}$ NMR spectrum for $\mathbf{4 d}$ derivative displays signals characteristic for both units. The signal related to the methyl protons of the ester group appears as a doublet at $3.62 \mathrm{ppm}$, integrating to 24 . The signal related to the $\alpha$-protons (Figure 3) appears as a quartet at $4.47 \mathrm{ppm}$, integrating to eight. The signals associated with the $\beta$ - and $\gamma$-protons appear as multiplets at $1.45-1.67 \mathrm{ppm}$, integrating to twenty four protons. The signals for the methyl groups attached to the $\delta$ carbon atoms appear at a higher frequency as two triplets at $0.87 \mathrm{ppm}$ and $0.77 \mathrm{ppm}$, each of these integrates to 24 . The signal associated with the amide NH protons appears as two doublets at $8.02 \mathrm{ppm}$ and $7.79 \mathrm{ppm}$, each of these integrates to four.

The signal for the diastereotopic methylene protons of the $\mathrm{OCH}_{2} \mathrm{CO}$ groups $\left(\mathrm{H}_{5}\right)$ appears as a pair of quartets at $4.36 \mathrm{ppm}$ and $4.46 \mathrm{ppm}$, integrating to eight each. The signals related to the $\mathrm{H}_{3}$ and $\mathrm{H}_{4}$ protons appear as two singlets at $6.89 \mathrm{ppm}$ for $\mathrm{H}_{3}$ and at $6.53 \mathrm{ppm}$ for $\mathrm{H}_{4}$. Each integrates to four. The signal associated with the $\mathrm{H}_{2}$ protons appears as a triplet at $4.77 \mathrm{ppm}$, integrating to four. The signals related to the undecyl "feet" are unchanged.

Reaction of the octa-acyl chloride resorcin[4]arene 3 with L-proline methyl ester afforded compound $\mathbf{4 e}$ in $69 \%$ yield. The ${ }^{1} \mathrm{H}$ NMR spectrum exhibits signals for both moieties. The signal related to the methyl protons of the ester group appears as a doublet at $3.69 \mathrm{ppm}$, integrating to twenty four. The signal related to the $\alpha$-protons at $4.38 \mathrm{ppm}$ is a quartet, integrating to eight. The signals associated with the $\beta$ - and $\gamma$-protons appear as multiplets at $1.90-2.15 \mathrm{ppm}$, integrating to thirty two. The signal related to the $\delta$-protons appears as a multiplet at $3.56 \mathrm{ppm}$, integrating to sixteen.

The signal for the methylene protons of the $\mathrm{OCH}_{2} \mathrm{CO}$ groups $\left(\mathrm{H}_{5}\right.$, Figure 3) appears as a broad doublet at $4.48 \mathrm{ppm}$, integrating to 16 . This broadening could be attributed to the slow rate of conformational interchange of the prolinepyrrolidine ring.(6) The signals related to the aromatic resorcin[4]arene protons $\left(\mathrm{H}_{3}\right.$ and $\left.\mathrm{H}_{4}\right)$ appear as a broad singlet, 
one at $6.82 \mathrm{ppm}$ for $\mathrm{H}_{3}$ protons and the other at $6.38 \mathrm{ppm}$ for $\mathrm{H}_{4}$ protons. Each of these integrates to four. The signal for $\mathrm{H}_{2}$ at $4.68 \mathrm{ppm}$ is a triplet and integrates to four. The signals related to the undecyl "feet" (R), remain essentially unchanged.

Compound $\mathbf{4 f}$ was synthesised in $64 \%$ yield by reacting L-tryptophan methyl ester with the octa-acid resorcin[4]arene 3. The ${ }^{1} \mathrm{H}$ NMR spectrum for this derivative displays signals characteristic for both units. The signal related to the methyl protons of the ester group at $3.68 \mathrm{ppm}$ appears as a doublet, integrating to twenty four. The signal associated with the $\alpha$ protons at $4.71 \mathrm{ppm}$ appears as a quartet, integrating to eight. The signal assigned to the $\beta$-protons at 3.11-3.25 ppm appears as a multiplet due to coupling to the $\alpha$-protons and integrates to sixteen. The signal assigned to the NH protons of the indole ring (Figure 3) appears as two singlets at $10.42 \mathrm{ppm}$ and $10.32 \mathrm{ppm}$, each of these integrates to four. The signal assigned to the tryptophan- $7^{\prime}$-protons at $7.48 \mathrm{ppm}$ appears as a triplet. The signal assigned to the tryptophan- $4^{\prime}-$ protons at $7.29 \mathrm{ppm}$ appears as pair of doublets. The signal related to the tryptophan-5'-protons at $7.02 \mathrm{ppm}$ is a triplet. The signal assigned to the tryptophan- $6^{\prime}$-protons at $7.00 \mathrm{ppm}$ appears as a triplet. The signal assigned to the tryptophan$2^{\prime}$-protons at $6.90 \mathrm{ppm}$ is a singlet. Each of these signals integrates to eight protons. The signal related to the amide $\mathrm{NH}$ protons appears as two doublets at $7.63 \mathrm{ppm}$ and $7.55 \mathrm{ppm}$, each integrates to four.

The signal for the diastereotopic methylene protons of the $\mathrm{OCH}_{2} \mathrm{CO}$ groups $\left(\mathrm{H}_{5}\right.$, Figure 3) appears as a pair of quartets at $4.26 \mathrm{ppm}$ and $432 \mathrm{ppm}$, each of these signals integrates to eight. The signals associated with the aromatic resorcin[4]arene protons appear as two singlets at $6.80 \mathrm{ppm}$ for $\mathrm{H}_{3}$ and at $6.47 \mathrm{ppm}$ for $\mathrm{H}_{4}$ protons, each of these signals integrates to four. The signal related to the methine protons $\left(\mathrm{H}_{2}\right)$ appears as a triplet at $4.63 \mathrm{ppm}$, integrating to four. The signals related to the undecyl "feet" are unchanged.

The ${ }^{1} \mathrm{H}$ NMR spectrum for $\mathbf{4 g}$ exhibits signals for both residues. The signal related to the $t$-butyl protons, which protects the carboxylic group, is a doublet at $1.40 \mathrm{ppm}$, integrating to seventy two. The signal for the $\alpha$-protons of this amino acid is a quartet at $4.46 \mathrm{ppm}$, integrating to eight. The signal for the $\beta$-protons appears as two pairs of doublets at $3.70 \mathrm{ppm}$ and $3.54 \mathrm{ppm}$ due to coupling to the $\alpha$-protons and each integrates to eight. The signal related to the $t$-butyl protons at the side chain, which protects the hydroxyl groups, at $1.09 \mathrm{ppm}$ is a doublet, integrating to seventy two. The amide $\mathrm{NH}$ protons signal appears as two doublets at $7.27 \mathrm{ppm}$ and $7.24 \mathrm{ppm}$, each integrates to four (Figure 3).

The signal related to the diastereotopic methylene protons of the $\mathrm{OCH}_{2} \mathrm{CO}$ groups $\left(\mathrm{H}_{5}\right.$, Figure 3) appears as four doublets at $4.36 \mathrm{ppm}, 4.28 \mathrm{ppm}, 4.25 \mathrm{ppm}$, and $4.18 \mathrm{ppm}$, each of these integrate to four. The presence of two serine units with bulky $t$-butyl groups at side chains per each aromatic ring could affect this splitting. The signals associated with the aromatic protons $\mathrm{H}_{3}$ and $\mathrm{H}_{4}$ appear as two singlets: one at $6.73 \mathrm{ppm}$ (for $\mathrm{H}_{3}$ ), and the other at $6.53 \mathrm{ppm}$ (for $\mathrm{H}_{4}$ ), each integrates to four. The signal related to $\mathrm{H}_{2}$ appears as a triplet at $4.63 \mathrm{ppm}$, integrating to four. The signals related to the undecyl "feet" are unchanged.

The ${ }^{1} \mathrm{H}$ NMR spectrum for $\mathbf{4 h}$ derivative displays signals characteristic for both moieties. The signal associated with the methyl protons of the ester group, is a singlet at $3.70 \mathrm{ppm}$, integrating to 24 . The signal assigned to the $\alpha$-protons for this amino acid at $4.44 \mathrm{ppm}$ is a quartet, integrating to eight. The signal related to the $\beta$-protons appears as two multiplets at $1.96 \mathrm{ppm}$ and $2.13 \mathrm{ppm}$ due to coupling to the $\alpha$-protons, each integrates to eight. The signal related to the $\gamma$-protons appears as a multiplet at $2.36 \mathrm{ppm}$, integrating to sixteen. The signal related to the methyl protons of the ester group at 
the side chain, appears as a singlet at $3.58 \mathrm{ppm}$, integrating to twenty four. The amide NH protons signal appears as two doublets at $7.66 \mathrm{ppm}$, integrating to eight.

The signal for the diastereotopic methylene protons of the $\mathrm{OCH}_{2} \mathrm{CO}$ groups $\left(\mathrm{H}_{5}\right.$, Figure 3$)$ appears as a pair of quartets at $4.30 \mathrm{ppm}$ and $4.32 \mathrm{ppm}$. Each of these integrates to eight. The signals associated with the $\mathrm{H}_{3}$ and $\mathrm{H}_{4}$ (aromatic ring protons) appear as two singlets, at $6.81 \mathrm{ppm}$ for $\mathrm{H}_{3}$ and at $6.55 \mathrm{ppm}$ for $\mathrm{H}_{4}$, each integrates to four. The signal for $\mathrm{H}_{2}$ appears as a triplet at $4.69 \mathrm{ppm}$, integrating to four. The signals related to the undecyl "feet" are essentially unchanged.

The ${ }^{1} \mathrm{H}$ NMR spectrum for $\mathbf{4 i}$ displays signals characteristic for both moieties. The signals related to the aromatic protons of carboxybenzyl group (Cbz) and the benzyl ester group (Bn) appear as a multiplet at 7.26-7.36 ppm, integrating to 80 . The signal for the methylene protons of Cbz group appears at $5.13 \mathrm{ppm}$ as a multiplet due to coupling with the $\alpha$-protons, and the one associated with the benzyl ester group ( $\mathrm{Bn})$ appears at $4.77 \mathrm{ppm}$, as a singlet, each integrates to 16 . The signal related to the $\alpha$-protons appears as a quartet at $4.44 \mathrm{ppm}$, integrating to eight. The signal for the $\beta$-protons appears as two multiplets at $1.82 \mathrm{ppm}$ and $1.78 \mathrm{ppm}$ due to coupling with the $\alpha$-protons, each integrates to eight. The signals related to the $\gamma$ - and $\delta$-protons appear as a multiplet at $1.39 \mathrm{ppm}$, integrating to 32 . The signal for the $\varepsilon$-protons appears as a quartet at $3.10 \mathrm{ppm}$, integrating to 16 . The signal for the $\varepsilon N H$-protons appears as a broad triplet at $6.61 \mathrm{ppm}$, integrating to eight. The amide NH protons signal appears as a pair of doublets at $7.61 \mathrm{ppm}$, and integrates to eight.

The signal for the diastereotopic methylene protons of the $\mathrm{OCH}_{2} \mathrm{CO}$ groups $\left(\mathrm{H}_{5}\right.$, Figure 3) appears as a pair of quartets at $4.27 \mathrm{ppm}$ and $4.35 \mathrm{ppm}$. Each integrates to eight. The signals related to the aromatic ring protons $\left(\mathrm{H}_{3}\right.$ and $\left.\mathrm{H}_{4}\right)$ appear as two singlets, each integrates to four: one at $6.84 \mathrm{ppm}$ (for $\mathrm{H}_{3}$ ) and the other at $6.59 \mathrm{ppm}\left(\right.$ for $\left.\mathrm{H}_{4}\right)$. The signal for $\mathrm{H}_{2}$ appears as a triplet at $4.68 \mathrm{ppm}$, integrating to four protons.

\section{References}

(1) Hogberg, A.G.S., Stereoselective Synthesis And Dnmr Study Of 2 1,8,15-22-Tetraphenyl 14 Metacyclophan3,5,10,12,17,19,24,26-Octols. Journal of the American Chemical Society 1980, 102, (19), 6046-6050.

(2) Abis, L.; Dalcanale, E.; Duvosel, A.; Spera, S., Structurally New Macrocycles From The Resorcinol Aldehyde Condensation - Configurational And Conformational-Analyses By Means Of Dynamic NMR, NOE, And T1 Experiments. Journal of Organic Chemistry 1988, 53, (23), 5475-5479.

(3) Bazzanella, A.; Morbel, H.; Bachmann, K.; Milbradt, R.; Bohmer, V.; Vogt, W., Highly efficient separation of amines by electrokinetic chromatography using resorcarene-octacarboxylic acids as pseudostationary phases. Journal of Chromatography A 1997, 792, (1-2), 143-149.

(4) Sansone, F.; Barboso, S.; Casnati, A.; Fabbi, M.; Pochini, A.; Ugozzoli, F.; Ungaro, R., Synthesis and structure of chiral cone calix 4 arenes functionalized at the upper rim with L-alanine units. European Journal of Organic Chemistry 1998, (5), 897-905.

(5) Frkanec, L.; Visnjevac, A.; Kojic-Prodic, B.; Zinic, M., Calix 4 arene amino acid derivatives. Intra- and intermolecular hydrogen-bonded organisation in solution and the solid state. Chemistry-a European Journal 2000, 6, (3), 442-453.

(6) Deslauri.R; Smith, I.C.P.; Walter, R., Conformational Mobility Of Pyrrolidine Ring Of Proline In Peptides And Peptide Hormones As Manifest In C-13 Spin-Lattice Relaxation-Times. Journal of Biological Chemistry 1974, 249, (21), 7006-7010. 